











\title{
UNIVE̊RSITY OF ILLINOIS
}

\section{Agricultural Experiment Station}

\author{
BULLETIN No. 117
}

\section{BITTER ROT OF APPLES}

Horticultural Investigations

By Joseph C. BLAlR

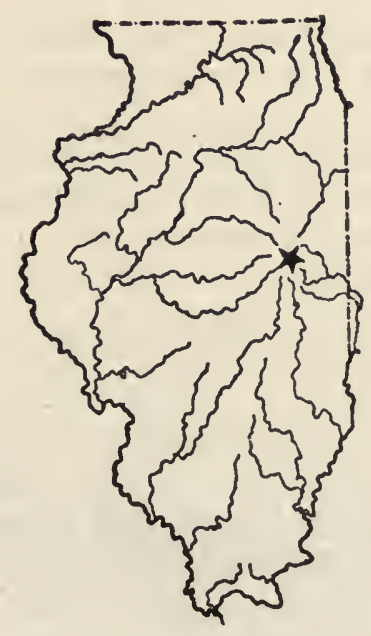

URBANA, ILLINOIS, AUGUST, 1907 


\section{Summary of Bulletin No.॰117}

1. A series of experiments was inaugurated in 1901 and continued over five years, having in view the determination of a means of controlling bitter rot in apples.

Page 483.

2. Experiments in 1901.

Page 484.

3. Elaborate precautions were taken to secure complete records and accurate data.

Page 487.

4. Experiments in 1902.

Page 490.

5. Spraying five times with Bordeaux mixture before bitter rot appeared in an orchard at Tonti, in 1902, resulted in a saving of 91.26 per cent of the crop liable to infection.

Page 491.

6. Spraying from three to five times after the appearance of the disease failed to save any considerable part of the crop in orchards at Tamaroa and Flora in 1902.

Page 495.

7. Experiments in 1903.

Page 500.

8. One spraying before the appearance of bitter rot was not sufficient to prevent ravages of the disease in an orchard at New Burnside, in 1903

Page 506.

9. Two spraying before the appearance of the disease greatly reduced the amount of bitter rot, but did not wholly control it in an orchard at Carbondale in 1903.

Page 511.

10. The work for $\mathbf{1 9 0 3}$ was not wholly successful owing to small crops and light infections in some of the orchards.

Page 512.

11. Experiments in 1904 .

Page 512.

12. Spraying the dormant wood with copper sulphate solutions and Oregon Wash proved ineffective in preventing bitter rot in 1904. Page 524.

13. Spraying with Bordeaux mixture after bitter rot infection had occurred was more successful in preventing the disease during the season of 1904 than in preceding seasons, but was ineffectual as compared with spraying before the first occurrence of bitter rot.

Page 524.

14. Experiments in 1905.

Page 524.

15. Scattering salt on the ground under the trees had no effect in controlling bitter rot.

Page 527.

16. Spraying with dust Bordeaux mixture proved ineffectual in checking bitter rot.

Page 529.

17. Moist warm weather during July and August was the ideal condition for the spread and development of bitter rot.

Page $5+1$.

18. Conclusions.

Page 547.

19. Recommendations for treatment of bitter rot.

Page 648 


\title{
BITTER ROT OF APPLES
}

\section{Horticultural Investigations}

\author{
By J. C. BLAiR, Chief IN Horticulture
}

During a period of five years the Department of Horticulture of the University of Illinois has conducted investigations on the control of the disease known as bitter rot of apples, and the Department of Botany under the direction of Dr. T. J. Burrill has made an exhaustive study of the life history and morphology of the fungus which causes the disease. The results of the work of the two departments are embodied in two bulletins on the bitter rot of apples, this one detailing the results of the horticultural investigations and having especial reference to experiments in spraying for the control of the disease, and its companion bulletin, No. I 8, comprising the results of the botanical investigations. The horticultural investigations were inaugurated in IgO I and were continued to the close of the season of 1905 . Twelve orchards were used for the work; seventeen series of experiments were conducted, experts from the Experiment Station being placed in immediate charge to insure the complete carrying out of the experiments as planned; individual records were made on I,269,30I apples, and very full and complete data embodying I728 typewritten pages were compiled from the observations made.

In the material which follows, the experiments of each year are first described separately and a summary of the conclusions reached and points unanswered at the close of each year follows the detailing of the results, after which are given a general summary of the results of the entire five years' investigations, a series of conclusions in brief form, and a series of recommendations for the control of the disease. 


\section{1}

In.April, I90I, the Department of Horticulture of the Agricultural Experiment Station of the University of Illinois began certain experiments, having in view the determination of the best treatment for bitter rot of apples. In this undertaking it had the coopperation of the Division of Vegetable Physiology and Pathology of the United States Department of Agriculture and the Department of Botany of the University of Illinois. The latter department was represented in this work by Dr. T. J. Burrill and the former by Dr. Herman Von Schrenk, in charge of the Mississippi Valley Laboratory at St. Louis, operated by the department first named above. The object of these experiments, as finally worked out by all interested, was to answer the following questions:

I. Can Bordeaux mixture by proper spraying be made to protect apples from bitter rot?

2. Is winter treatment of the dormant trees of any assistance in the process?

3. Is early spraying more advantageous than late spraying in the treatment of this disease?

4. Are any other fungicides superior to Bordeaux mixture in the treatment of this special malady?

On account of the great fluctuations in the amount of bitter rot occurring annually, the non-appearance of the disease during any one season in any or all of the experimental plats was anticipated, and the consequent uncertain results of the work, so far as the control of the disease is concerned, would have to be overcome by continuing the operations through a series of years. The experiments were, therefore, started with the expectation of continuing them for three years, since any less time would have been insufficient to reach definite conclusions. Because of the failure of the disease to appear in some of the orchards under experimentation and on account of partial failures of the apple crop in certain seasons, the work was carried on for two years longer, or, in all five years.

The plan of this experiment involved the laying off of plats, as suggested below, in duplicate and in triplicate, in some commercial orchards in Illinois, and in giving these plats thorough spraying in accordance with this plan. This plan was the one followed in Missouri and in Virginia by the United States Division of Vegetable Physiology and Pathology.

The following is an outline of the experiments:

Plat I-Winter spraying only-Spray plat with Bordeaux mixture before the buds swell, applying the spray until the trunk and buds are blue.

Plat II-Combined winter and spring spraying-First treatment, winter spraying before buds push; second treatment, when cluster buds are open and flower buds are exposed; third treatment, 
when the last of the petals are falling; fourth treatment, seven to ten days later; fifth treatment, ten days later.

Plat III-Early spraying without the winter treatment-Same as above with first treatment left off; that is, second, third, fourth, and fifth sprayings.

Plat IV - Early spraying continued until summer-second, third, fourth, and fifth sprayings, with four or five treatments more at intervals of two weeks until about the middle of August.

Plat $V$-Late spraying-Commenced when the fruit was about an inch in diameter and sprayed four or five times. These sprayings were on the same dates as the last four or five treatments of Plat IV.

Late applications were made with ammoniacal copper carbonate solution on plats not before treated. Some were made even after the disease had started, untreated trees outside of the plats already referred to being used for the late spraying.

These experiments as outlined were undertaken in the orchards of J. B. Brokaw of Tonti, N. B. Morrison of Odin, and H. M. Simpson \& Sons of Parkersburg. The work at Tonti was abandoned, so far as the Experiment Station was concerned, after the second application, owing to a misunderstanding on the part of the owner of the orchard, who sprayed the check plats as well as those which were to receive the applications in the schedule. The orchards at Parkersburg and Odin were unattacked by bitter rot, only five infected apples being found in the entire crop at the former place, and none at the latter.

When it became evident that bitter rot was not likely to develop to any serious extent in the orchards at Parkersburg and Odin, an orchard was secured from Dr. Daniel Berry, near Carmi, where the disease had made its appearance. Here it was impossible to test the value of the winter treatment of the dormant wood or to compare the value of the early with the late treatment, since only the latter could be applied.

Five rows of ten trees each were selected in the worst infected portion of the orchard. All were Ben Davis except one or two Winesap and one Aiken, which were not included, however, in the picking of the crop. The trees were about eighteen years old.

Applications were made as follows: August 23d two rows were given Bordeaux mixture and two rows were sprayed with ammoniacal copper carbonate solution, leaving one row between as a check. September I Ith two of the above rows were treated with a second application of Bordeaux mixture and ammoniacal copper carbonate solution, respectively.

From four trees of each sprayed row the infected apples were removed (both from the tree and from the ground) after the first application was made.

The following table gives the results of the season's operations. 


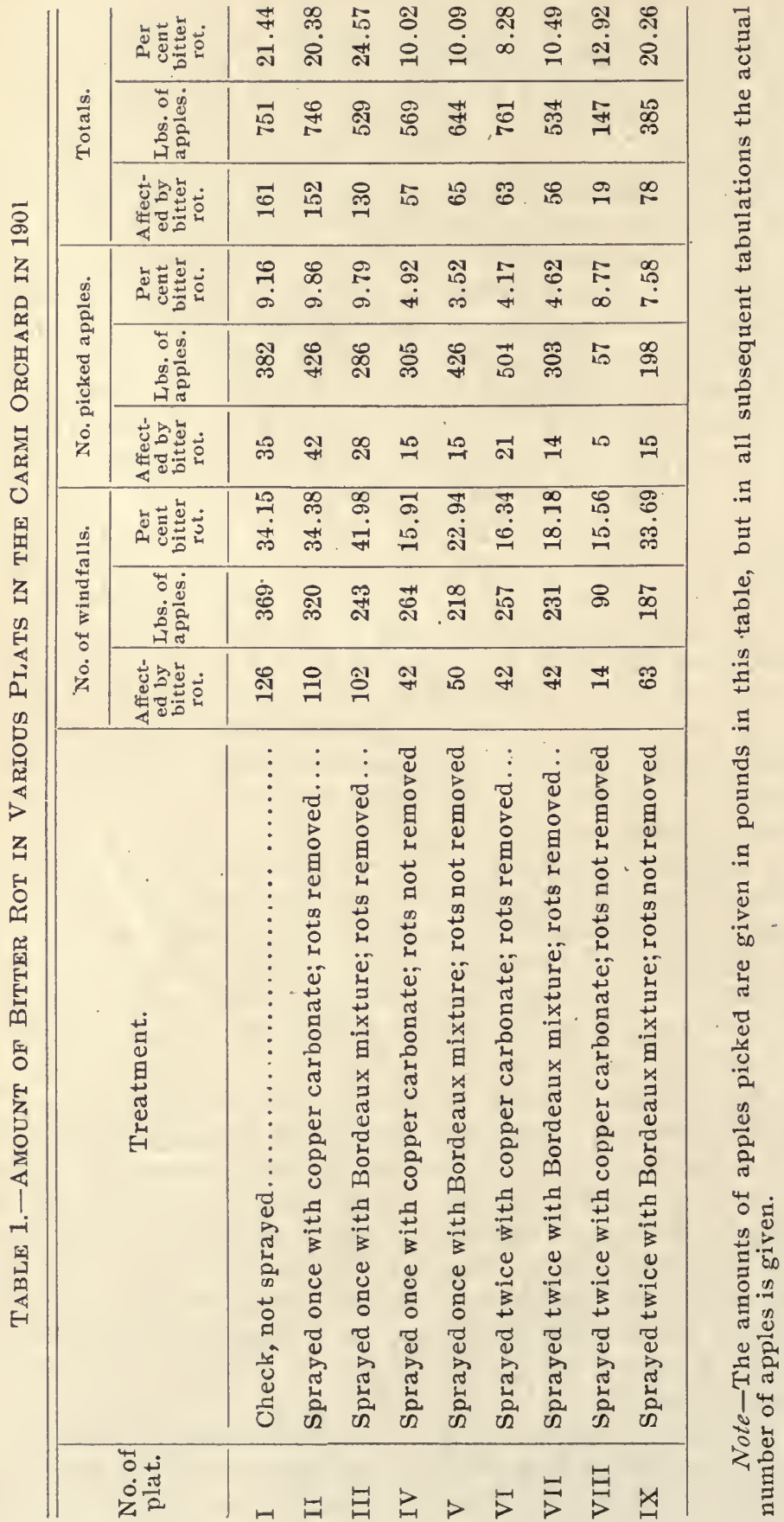


It will be seen from a perusal of the above table that spraying in most cases reduced the amount of bitter rot among both windfalls and picked fruit, effecting a saving of from 8 percent to 14 percent of the entire crop, or from 40 percent to $6 \mathrm{I}$ percent of the fruit liable to infection (Plats VIII and VI, respectively). In Plats II, III, and IX, however, the percentages of rot ran very high in spite of the spraying, indicating either that these plats were more severely infected than the others or that the spray was ineffective in preventing the ravages of the disease. It is probable that both causes affected the result somewhat for even in Plat VI, where the control was most complete, the protection was far from perfect. The results clearly indicate, therefore, that spraying but once or twice with Bordeaux mixture or copper carbonate solution is not a perfectly effectual way of controlling bitter rot. The removal of affected fruits, too, apparently failed to prevent the spread of the disease.

\section{CONCLUSIONS FOR IOOI}

While the work during Igor yielded no data of sufficient conclusiveness to warrant definite recommendations for the treatment of bitter rot, it as least served the useful purpose of pointing out lines along which the work should be conducted in succeeding seasons. Particularly was it valuable in emphasizing the necessity of having all conditions of the plats under as perfect control as the nature of the experiment would permit. In the work of 1902 and in all subsequent work every care was taken to make the experimental conditions as perfect as possible. The following important factors were especially considered in conducting the investigations:

I. The Infection Factor:-The success of experimental work in spraying for any disease must be very largely dependent on the uniformity and amount of infection of the plats under consideration. If the infection is not uniform throughout, inaccuracy in results is bound to occur unless very complete precautions are taken to overcome the influence of variable infection. If the amount of infection is very slight in all the plats, no wide differences in results can occur, and small differences leave doubt as to whether the results are to be ascribed to fluctuations in infection or to differences in the treatments of the various plats under investigation.

In case of bitter rot of apples the infection factor was found to be exceedingly variable and very difficult of control, and the following precautions were taken to eliminate its unevenness and uncertainty.

(a) In all experiments orchards were selected which in previous years had been severely and uniformly attacked by bitter rot, and in which it was confidently expected that, in a season at all favorable to the development of the disease, bitter rot would be present in sufficient quantities for experimental purposes. 
(b) The experience of Igor having shown that the precaution of selecting orchards known to have been infected in previous years was insufficient to insure good experimental conditions for investigations on spraying for bitter rot in any particular season, plans were made to continue experimental work over a series of years in certain orchards, and thus insure satisfactory conditions at some time or other during the progress of the experiments, and eliminate by large totals the effects of uneven or uncertain infection.

(c) A large number of orchards were used in the experiments in order to lessen the factor of variability in infection. In all, twelve orchards were employed and some seventeen series of experiments were conducted in the course of the five years of bitter rot investigation.

(d) As a further precaution the plats of trees were made unusually large, for investigations of this kind, numbering for the most part from fifteen to thirty or more trees to the plat, with control plats of at least ten trees each. Where more than three plats were concerned in an experiment, as was the case in most of the orchards selected for work during 1903, I904, and 1905, two or more check or control plats were reserved in each series in order that the amount of infection in each part of the orchard might be more accurately measured and adjoining plats compared therewith.

2. The Crop Factor:-The amount of the crop, in a number of instances, proved to be an exceedingly important consideration in the experimental work with bitter rot. The years I90I, I903, I904, and I905 were all more or less unfavorable for the apple crop in Illinois, and on this account certain of the experimental orchards yielded disappointing returns. Where the crop was light and scattering the disease spread much less rapidly than where the crop was large and the apples hung closely together. Thus the infection in these orchards was less uniform than in orchards producing good crops. Moreover, in certain orchards the crop was so light as to make the investigations of comparatively little value, one or two series of experiments being abandoned on account of the failure of the trees to set a crop of apples.

The measures taken to guard against failure of the experiment through failure of the crop were practically the same as those adopted to guard against failure from uneven and uncertain infection, $i$. $e$, continuing the experiment over a considerable number of years, conducting experiments in several orchards each year, and using large numbers of trees in each plat. In addition to these precautions, where the plan of the experiment would permit it, orchards were chosen for experimental work after the fruit had set, as in the Allen orchards near Carbondale in I903, thus practically insuring a crop. 
3. The Wcather Factor:-The weather factor is so closely associated with the infection factor as to need only passing mention in that connection. But it is also important in its influence on the treatments given the various plats, since heavy rains wash off some of the spray materials and thus unavoidably interfere to a greater or lesser extent with the plan of the experimenter. Again the only recourse of the investigator is to extend his observations over a series of years and average his results or wait for favorable conditions.

4. The Variety Factor:-Certain varieties have been found to be more susceptible to bitter rot than others, though it is probable that no variety is entirely immune from the disease. For the sake of uniformity, therefore, the most of the work was confined to the Ben Davis, a variety which is fairly subject to the disease and is more extensively grown in the bitter rot regions of Illinois than any other. A very complete series of experiments was carried on, however, in an orchard at Flora, with the Willow Twig variety, an apple notoriously susceptible to the bitter rot fungus, and a few isolated experiments were conducted on Jonathan, Winesap, and Huntsman varieties in other orchards at various times. For the most part the experiments were made in blocks of trees composed almost wholly of one variety, and in cases where the plats contained more than one variety the results for each are recorded separately.

5. Factor of Preparation and Application of Spraying Materials: In the work of 1902 and in all subsequent seasons every care was taken to follow the spraying schedule exactly throughout the season. The experimental orchards were placed immediately in charge of employees of the Horticultural Department, the employee in charge remaining at the orchard throughout the entire season to conduct the experiment and make the records. Thus the preparation and application of the spray mixtures was attended to directly by expert men. Good fresh chemicals were used each season and the mixtures applied were prepared in accordance with the most approved spraying practice. In this way the chances for error in this direction were reduced to a minimum.

But in spite of all precautions disappointments were more frequent than were complete successes in the results which were obtained during the four seasons of I901, I902, I903, and 1904. Small crops in some of the orchards, failure of bitter rot to appear in some orchards, and, in spite of the large plats and the careful choice of orchards, the very uneven distribution of the infection in others, were responsible for the inconclusive results which were obtained from several of the experiments. In a number of orchards, however, conditions proved very favorable for the performance of the experiments, and uniform and satisfactory data were obtained 
therefrom which appear sufficiently significant to be used as a basis for certain definite recommendations for the prevention and control of bitter rot of apples.

\section{2}

The work for 1902, which from this time to the conclusion of the experiments was carried on independent of the Federal authorities, was carefully planned with a view of determining the following points :

I. The value of early sprayings repeated at intervals of ten days up to the time of the appearance of the disease.

2. The value of spraying shortly before the appearance of the disease.

3. The value of three applications of spraying material at intervals of ten days, beginning after the appearance of the disease.

4. The value of five applications of spraying material, at intervals of ten days, beginning after the appearance of the disease.

5. The value of making applications after every rain, beginning after the appearance of the disease.

Three orchards were selected in which it seemed probable from past records that the rot would surely develop. These orchards were located near Tonti, Tamaroa, and Flora. In order that the operations might be carried forward on a sufficiently large scale to render the results of practical value and leave no uncertainty regarding the conclusions, it was decided to undertake the investigation of only a part of the above enumerated points in each orchard. Accordingly the operations at Tonti were carried on with a view of determining the first two points; the operations at Tamaroa, the third and fourth points; and those at Flora, the fourth and fifth points. In all of the orchards check plats were left unsprayed for purposes of comparison.

The material used in all of the spraying was Bordeaux mixture of the usual strength-four pounds lime, four pounds copper sulphate, and fifty gallons water.

\section{Orchard of J. B. Brokaw, 'Tonti, Marion County, igoz}

Three plats consisting of fifteen or more trees each were laid out in this orchard, all the trees in each. plat being Ben Davis with the exception of two Huntsman located at one end of the block, in all six trees of the Huntsman equally divided among the three plats.

Plat $I$ was sprayed with Bordeaux mixture May $15^{\text {th }}$, 28th, June 7 th, and $I 7$ th. The spraying designed for June $27^{\text {th }}$ was abandoned on account of the soft ground resulting from almost continuous rains, and July 2d, when the Ben Davis trees were sprayed, 
it was impossible to reach the Huntsman which were located on somewhat lower ground than the rest of the plat. Thus the Huntsman were not sprayed until July gth.

Plat II was sprayed with Bordeaux mixture May I $5^{\text {th, July }}$ 2d, 9th, and I2th, excepting the Huntsman which received their first application July 9 th and the second one July I 3 th.

Plat III was not sprayed.

On account of the somewhat different treatment of the Ben Davis and the Huntsman trees in this experiment, and on account of the greater susceptibility of the latter to bitter rot fungus; the results of the work in the Tonti orchard will be given in separate tables. Records of fallen apples were made July 9th, 28th, 3Ist, August 8th, I $3^{\text {th }}$, 20th, 28th, September 9th, 20th, 30th, and October Ist. All infected apples were counted as were also those free from rot at each picking. September 3oth and October ist the apples were picked from the trees, examined and counted, and record made of the number of specimens showing bitter rot and of the total number of specimens in the crop. The results are shown in Table 2.

While the results of the experiment in the Brokaw orchard as shown in the above tabulation are not conclusive, there is considerable evidence to show that spraying may be effective in checking bitter rot. 44.95 percent of all the fruit on the Ben Davis trees which were not sprayed was attacked by bitter rot, whereas only 3.93 percent was affected in the early sprayed plat, a saving of 91.26 percent of the fruit liable to attack by bitter rot, where the trees were sprayed five times before any rot appeared. Spraying once shortly before the rot appeared and twice afterwards also checked the disease, effecting a saving over the check plat of 63.00 percent of the fruit liable to bitter rot. In this respect, however, the earlier sprayings proved considerably the more effective.

In the Huntsman the percentage of rot in all plats was very much higher than in the Ben Davis. It will be remembered, however, that in the case of the early sprayed plat two very important applications of Bordeaux had to be omitted on account of difficulty in getting to the trees, those of June $27^{\text {th }}$ and July $2 \mathrm{~d}$, leaving a period of twenty-two days between sprayings in the case of Plat I of the Huntsman, so that when the spray was finally applied the bitter rot infection was already quite general. Even then there was effected a saving of 38.66 percent over the check plat and of 34.45 percent over the plat sprayed after the rot appeared. The discouraging part about the Huntsman experiment is the very small number of apples which remained on the tree until picking time. Such-apples as did remain, however, were all found on the sprayed plats. 


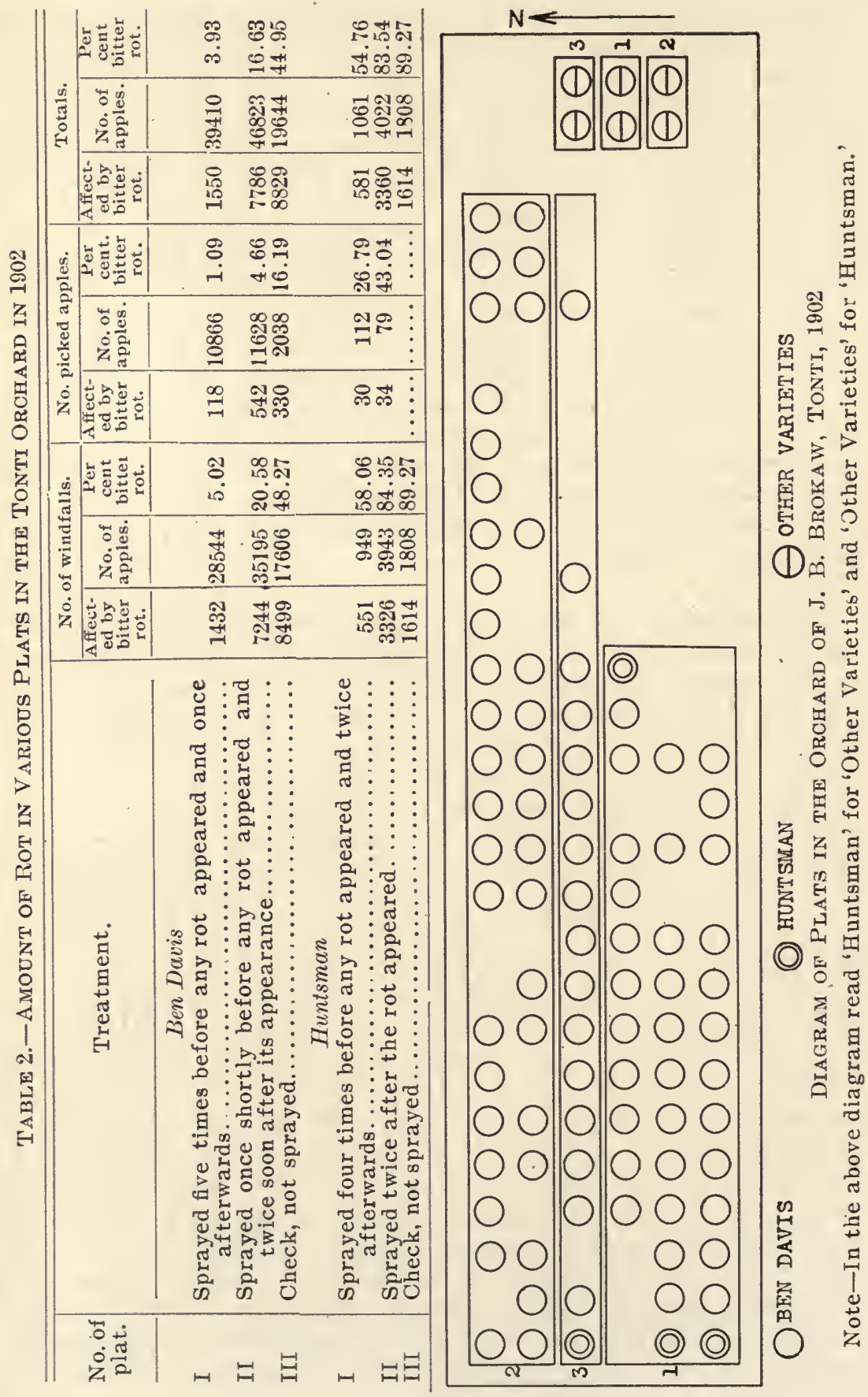


The following table gives the relative percentages of saving effected by the different treatments applied:

Table 3,-Savings EFFeCted By SPRAYING IN The TONTI ORChaRd IN 1902

\begin{tabular}{|c|c|c|c|}
\hline $\begin{array}{l}\text { No. of } \\
\text { plat. }\end{array}$ & Treatment. & $\begin{array}{l}\text { Saving } \\
\text { over } \\
\text { plat II. }\end{array}$ & $\begin{array}{c}\text { Saving } \\
\text { over } \\
\text { check } \\
\text { III. }\end{array}$ \\
\hline & Ben Daris & $\begin{array}{l}\text { Percent- } \\
\text { age }\end{array}$ & $\begin{array}{l}\text { Percent- } \\
\text { age }\end{array}$ \\
\hline I & 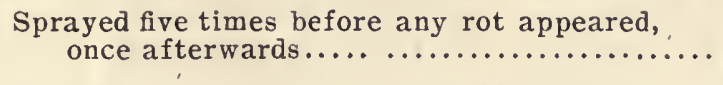 & 76.37 & 91.26 \\
\hline II & $\begin{array}{l}\text { Sprayed once shortly before any rot appeared } \\
\text { and twice soon after it appeared............. }\end{array}$ & & 63.00 \\
\hline & Huntsman & & \\
\hline I & 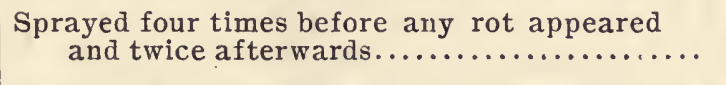 & 34.45 & 38.66 \\
\hline II & Sprayed twice after the rot appeared........... & & 6.42 \\
\hline
\end{tabular}

Conclusions:- In so far as this experiment was expected to answer the question of the relative efficiency of early and late applications of the spray, it is clearly in favor of the early spraying.

Orchard of F. L. Williams \& Son, Tamaroa, Perry County, 1902

The Ben Davis variety of apples was the only one experimented with in this block. One application of Bordeaux-Paris green mixture was made by the owner of the orchard May Ist. This application was for the purpose of controlling apple scab and codling moth. Three plats of fifteen trees each were reserved for the experiment and were treated as follows, the object being to test the value of different numbers of late applications for the suppression of bitter rot:

Plat I was sprayed with Bordeaux mixture after the disease had become thoroughly established, July r6th, 26th, August 6th, r6th, and 27 th, in all, five times.

Plat II was sprayed with Bordeaux mixture after the disease had become thoroughly established, July I6th, 26th, and August 6 th, in all, three times.

Plat III was not sprayed.

Bitter rot was first discovered in the plats July 5 th. Records on the fallen apples were made July 29th, August 8th, I6th, 22d, 27 th, September 3d, Ioth, I9th, and October 8th. Records of infected and non-infected fruit were made similar to those at the Tonti orchard. The apples were picked from the trees October 6 th, 7 th, and 8th, and the records when completed furnished data for Table 4. 


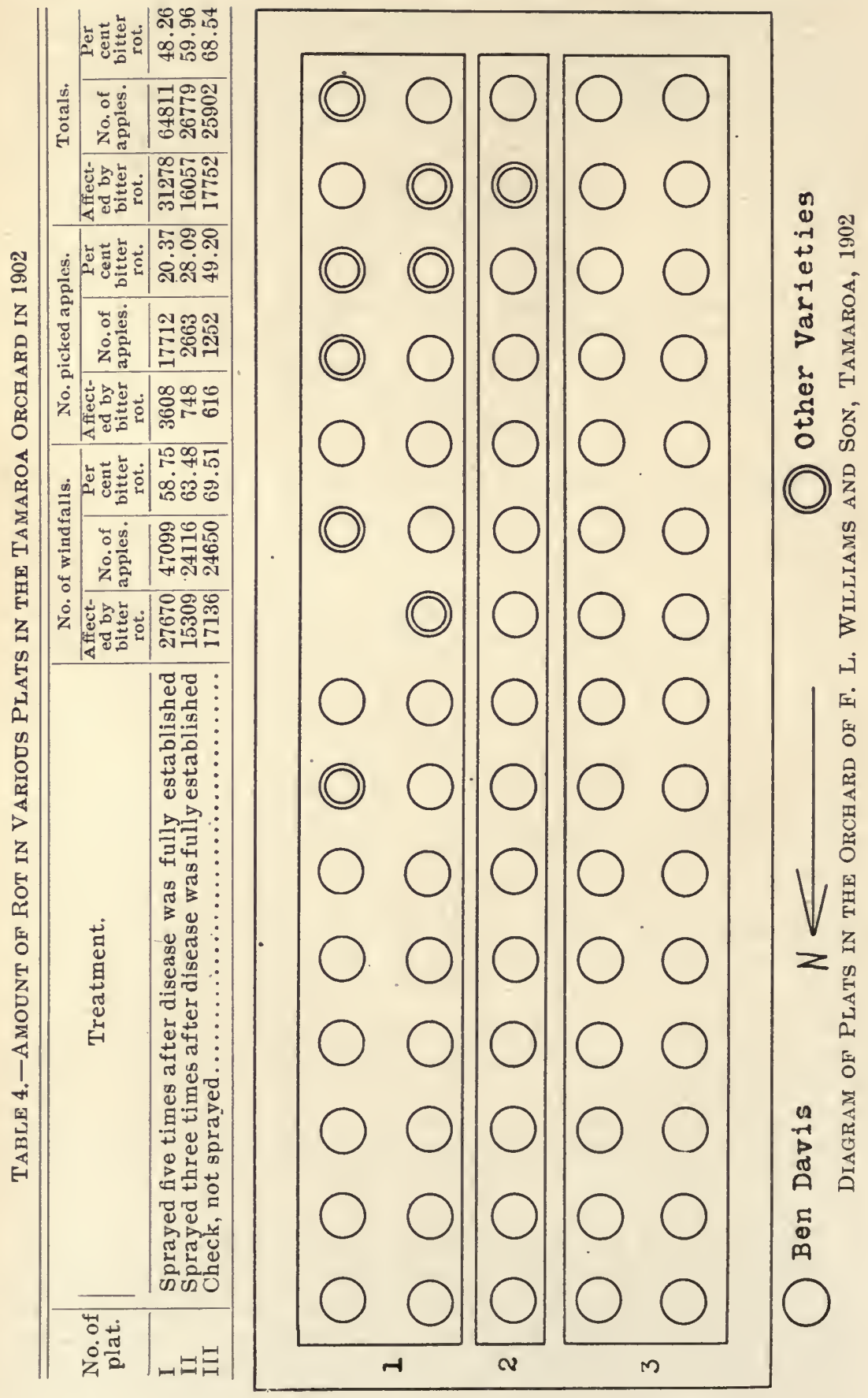


It will be seen from Table 4 that bitter rot developed to a considerably greater extent in the Tamaroa orchard than in the Tonti orchard, the check plat in the former showing an infection of 68.54 percent and the latter an infection of 44.95 percent for the Ben Davis. So far as the effect of the spray in controlling the disease is concerned the results only indicate that it was markedly ineffective. Even five applications failed to save any large amount of the crop, 48.26 percent of the entire crop being affected with the disease, as compared with 68.54 percent for the check plat. The results for the picked fruit alone are somewhat more favorable to both the sprayed plats, only 20.37 percent of the picked fruit on Plat I and 28.09 percent on Plat II being infected, as compared with 49.20 percent on the check plat.

The following table shows the saving in percentages effected by each treatment :

Table 5.-Saving in Percentages Effected by Spraying in the TAMAROA ORCHARD IN 1902

\begin{tabular}{|c|c|c|c|}
\hline $\begin{array}{l}\text { No. of } \\
\text { plat. }\end{array}$ & Treatment. & $\begin{array}{c}\text { Saving } \\
\text { over } \\
\text { plat II. }\end{array}$ & $\begin{array}{c}\text { Saving } \\
\text { over } \\
\text { check } \\
\text { III. }\end{array}$ \\
\hline & & $\begin{array}{l}\text { Percent- } \\
\text { age }\end{array}$ & $\begin{array}{l}\text { Percent- } \\
\text { age }\end{array}$ \\
\hline I & $\begin{array}{l}\text { Sprayed five times after disease was fully es- } \\
\text { tablished } \ldots \ldots \ldots \ldots \ldots \ldots \ldots \ldots \ldots \ldots \ldots \ldots \ldots \ldots \ldots \ldots\end{array}$ & & 29.59 \\
\hline II & $\begin{array}{l}\text { Sprayed three times after disease was fully } \\
\text { established } \ldots \ldots \ldots \ldots \ldots \ldots \ldots \ldots \ldots \ldots \ldots \ldots\end{array}$ & & 12.52 \\
\hline
\end{tabular}

Conclusions:-Late spraying had some effect in decreasing the amount of injury done by bitter rot. Five late sprayings effected a saving over three sprayings, of I9.5I percent, and over the check plat, of 29.59 percent of possible infection of bitter rot, but as compared with the early spraying in the Tonti orchard, it was much less effective in controlling the disease.

\section{Orchard of Dale Mann, Flora, Clay County, igoz}

In this orchard but one variety was under treatment, the Willow Twig. The block, excepting the check plat, was sprayed just after the petals fell and again two weeks later, by the owner of the ors chard. This was for scab and codling moth and not a part of the regular experimental work. As in the Tonti and Tamaroa orchards three plats of fifteen trees each were laid out, the object being a comparison of the value of spraying at regular intervals of ten days 
after the appearance of the rot with spraying after every rain after the appearance of the rot. It happened, however, that rain fell just previous to the regular time for spraying throughout the entire season and hence the two sprayed plats received the same treatments. The plats were sprayed as follows:

Plat I-This plat was to be treated after the bitter rot became established and all subsequent applications were to be governed by weather conditions. Following out this program applications were made July I4th, $25^{\text {th }}$, August $5^{\text {th }}$, I $5^{\text {th }}$, and $25^{\text {th }}$. On the date of the first application infection of bitter rot was found to be general throughout the orchard. Rains occurred just before each of the applications above referred to.

Plat II-Sprayed with Bordeaux mixture every ten days regardless of rain, July $14^{\text {th }}$, 24th, August 5th, I $5^{\text {th, }}$ and $25^{\text {th. }}$.

Plat III-Check plat, not sprayed.

Records on the fallen apples were made July 25th, 3oth, August $5^{\text {th }}$ I $5^{\text {th }}, 2$ Ist, 25th, September Ist, 8th, I $7^{\text {th }}$, 24th, and October I 5 th.

The fruit was picked from the trees October I 4 th and I 5 th, the apples were counted, and the records completed.

The results of the experiments in this orchard are tabulated in Table 6.

The average percentage of bitter rot for the two sprayed plats is 59.89 percent. "This shows that an average of 23.43 percent of the entire crop was saved by spraying five times after the appearance of the disease; that is, the percentage of the crop saved was about the same as in the case of the Ben Davis receiving similar treatment at Tamaroa. The percentage of rot in the check plat, 83.32 , shows that the Willow 'Twig at Flora was attacked worse than the Ben Davis at Tamaroa or Tonti, and nearly as bad as the Huntsman at the latter place. In this table the most interesting results from the orchardists' view point appear in the column of picked fruits. The saving effected by the spraying in the case of the two sprayed plats was, taking the average for Plats I and II, 36.85 percent of the fruit picked, and at the same time, the total proportion of fruit remaining upon the sprayed trees was almost four times greater than that remaining upon the unsprayed trees. 


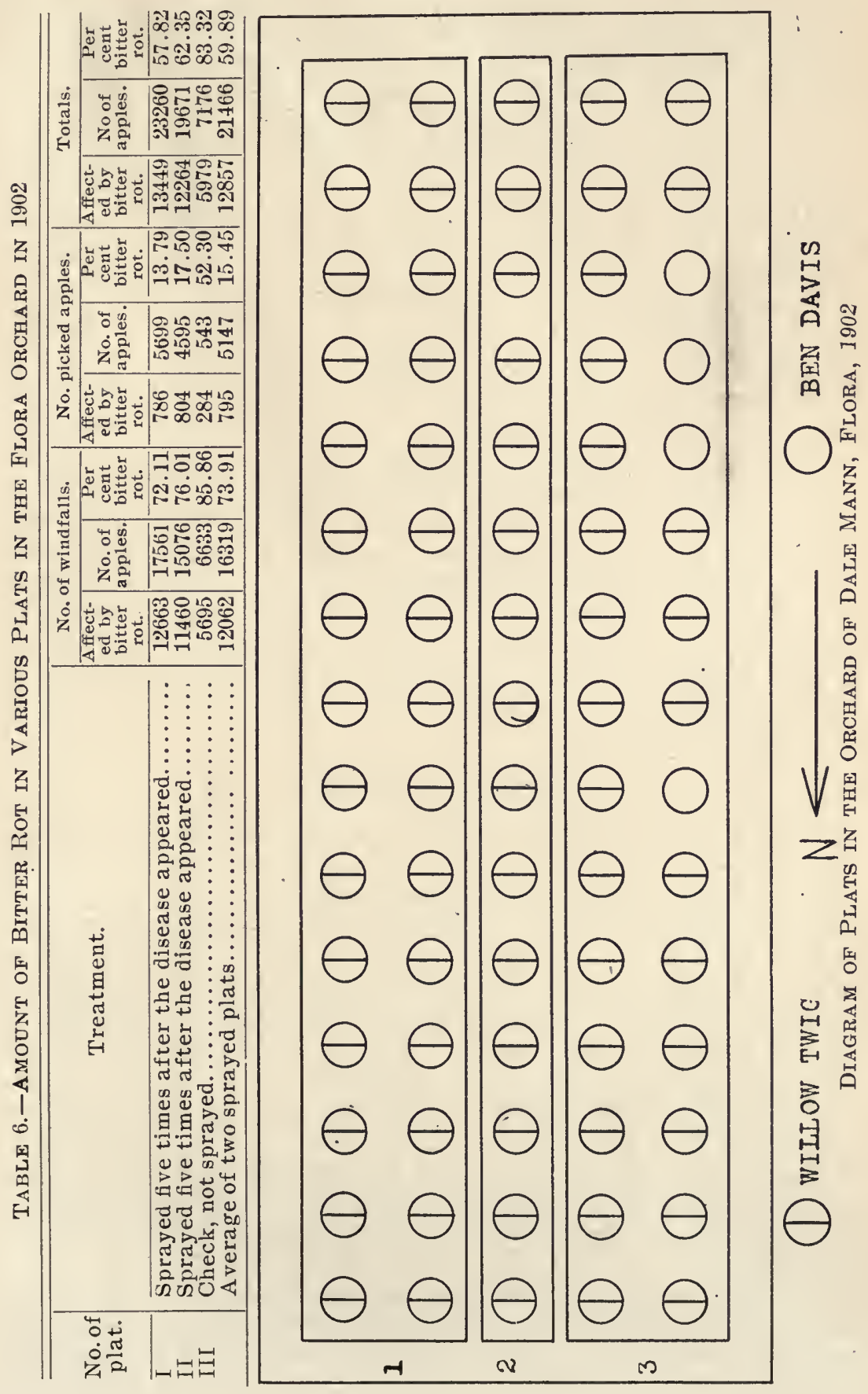


The saving in percentages of the crop liable to bitter rot effected by the spraying is as follows:

Table 7.-Saving EFfected by Five Sprayings After the AppearANCE OF THE DISEASE

\begin{tabular}{|c|c|c|c|}
\hline $\begin{array}{l}\text { No. of } \\
\text { plat. }\end{array}$ & Treatment. & $\begin{array}{l}\text { Saving } \\
\text { over } \\
\text { plat II. }\end{array}$ & $\begin{array}{c}\text { Saving } \\
\text { over } \\
\text { check } \\
\text { III. }\end{array}$ \\
\hline & $\begin{array}{l}\text { Average, sprayed five times after the disease } \\
\text { appeared } . . . \ldots \ldots \ldots \ldots \ldots \ldots \ldots \ldots \ldots \ldots \ldots \ldots \ldots \ldots \ldots \ldots\end{array}$ & & 28.12 \\
\hline
\end{tabular}

Of the picked crop an apparent saving in apples liable to infection of 70.46 percent was effected.

Conclusions:- Owing to the peculiar weather conditions which prevailed during the season of 1902 this experiment failed to answer the question as to whether spraying at regular intervals after the appearance of the rot, regardless of weather conditions, was more or less efficient than spraying after every rain. It did, however, show that spraying after the appearance of the rot would check the disease, though in this instance not completely enough to be recommended commercially.

The results of the experimental work in 1902 are briefly summed up in Table 8, page 499.

\section{CONCLUSIONS FOR 1902}

I. In every instance spraying reduced the damage done by bitter rot.

2. The saving effected by spraying varied from 91.26 percent of the total infection possible, as shown by the check plats, to 6.42 percent.

3. Spraying five times before the rot appeared and once afterwards proved by far the most efficacious preventive of the disease.

4. Spraying after the disease appeared prevented fresh infections but did not save the fruits already attacked.

5. Huntsman and Willow 'Twig-apples were more susceptible to bitter rot than Ben Davis.

6 . The securing of a thorough coating of Bordeaux mixture on the apples before the first appearance of the disease was more important than spraying at stated intervals with reference to time and rains.

7. Since the bitter rot appeared earlier than usual in 1902, the first and most general infection occurring between June 26 th and July $2 \mathrm{~d}$, it would seem that the early spraying should be done between June Ist and $25^{\text {th }}$, and, if necessary, the coating of Bordeaux mixture be maintained by later applications. 


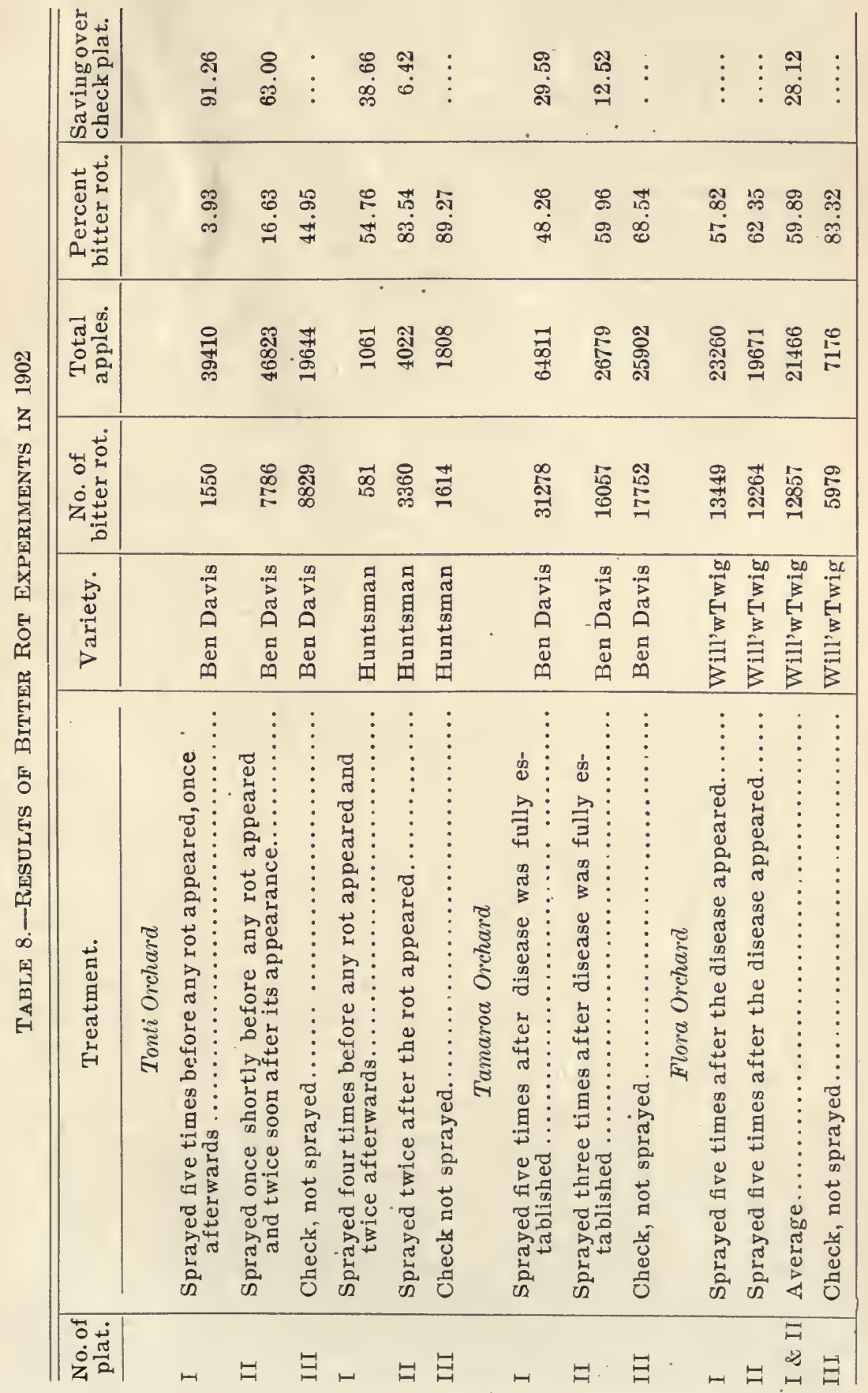




\section{3}

The work for 1903 was planned along lines similar to that for the preceding year; plats being laid out as before at Olney, Flora, and Tamaroa. This season, however, was a most unfortunate one, very few apples setting in any of the orchards and consequently work was abandoned at Flora, while in the Olney and Tamaroa orchards work was carried through, hoping that the scattered fruit might develop a sufficient amount of the disease to warrant the drawing of some conclusions. When it was found that these results were not likely to be of a very definite character, orchards were selected at Carbondale and New Burnside, where it was known that there was considerable bitter rot in preceding years and where the rot for this particular season was very promising. It was designed to answer the following problems by means of these experiments:

I. The value of spraying dormant wood in the fall with a copper sulphate solution containing one pound of the sulphate to fifteen gallons of water.

2. The value of spraying dormant wood in the spring with a copper sulphate solution containing one pound of the sulphate to fifteen gallons of water.

3. The value of spraying three times in July with Bordeaux mixture.

4. The value of spraying at intervals of ten days after the first three sprayings until after July ist with Bordeaux mixture.

5. The value of spraying four times in June at weekly intervals with Bordeaux mixture.

6 . The value of spraying so as to coat the fruit thoroughly with Bordeaux mixture when bitter rot first appears.

7. The value of spraying so as to coat the fruit thoroughly with Bordeaux mixture after bitter rot has become thoroughly established.

The Bordeaux mixture used in spraying for bitter rot in these experiments consisted of four pounds of copper.sulphate and four pounds of lime to fifty gallons of water. Applications of spray made early in the season for scab, canker worm, and codling moth consisted of Bordeaux mixture prepared as for bitter rot to which was added four ounces of Paris green. Plats which were reserved as checks received only the early sprayings for scab, canker worm, and codling moth.

\section{Orchard of J. L. Zook, Olney, Richland County, I903}

The variety selected in this orchard was Ben Davis. The trees were located on a comparatively level tract in the heart of a large commercial orchard. Nine plats were laid out, all of which con- 
tained fifteen bearing trees with the exception of check plat No. 3 , which contained only ten trees. All plats received two applications of spray for scab and codling moth, the first just after the petals had fallen, April 3oth, and the second, one week later, May 7 th and 8th. After this the plats were treated as follows :

Plat I-Sprayed with copper sulphate solution, one pound to fifty gallons of water, November 24, 1902.

Plat II-Sprayed with copper sulphate solution, one pound to fifty gallons of water, March 28, I903.

P.lat III-Check plat, not sprayed for bitter rot.

Plat IV-Sprayed with Bordeaux mixture July 2d, IIth, and 2 Ist.

Plat $V$-Sprayed with Bordeaux mixture May 18 th, 28th, June 6 th, I8th, 27th, and July 8th.

Plat VI-Sprayed with Bordeaux mixture June 5th, I Ith, i8th, and 25 th.

Plat VII-Check plat, not sprayed.

Plat VIII-This plat was to have been sprayed as soon as rot appeared but, as the disease was almost wholly wanting, this treatment was not given.

Plat IX-This plat was to have been sprayed when the disease became permanently established but this treatment was withheld as in the case of the treatment for Plat VIII.

The disease was first noticed August 7 th. Records of fallen apples were made July 27th, August Ioth, 20th, 25th, September $3 \mathrm{~d}$, I 5 th, and October I 4 th. The crop was picked from the trees October I4th. Table 9 shows the amount of bitter rot which developed under each treatment:

No conclusions whatever are to be drawn from the work in the Olney orchard for 1903 . The very slight fluctuations between plats may easily be the result of slight circumstances of variation impossible of control in an orchard experiment, as for example a few more centers of infection in one plat than another, differences in crop, and other conditions more or less difficult of discernment.

\section{Orchard of F. L. Wilitiams \& Son, Tamaroa, Perry County, 1903}

The experiments conducted in the Olney orchard were duplicated in the Tamaroa orchard. The same number of plats was used and the time of applying the various treatments was practically the same. Bitter rot first appeared in this orchard July 6 th, but, as in the Olney orchard, it proved to be so scarce as to make the results absolutely inconclusive and unreliable. The crop, too, was so light and scattering as to interfere with the work very materially. The data gathered are summarized in Table Io, p. 504. 


\begin{tabular}{|c|c|c|c|c|c|c|c|c|c|c|}
\hline \multirow{3}{*}{ 递 } & ن. & 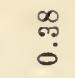 & $\begin{array}{l}128 \\
\text { ij } \\
0\end{array}$ & $\stackrel{0}{\circ}$ & ثิ & $\stackrel{1}{\circ}$ & $\frac{\pi}{0}$ & $\stackrel{19}{0}$ & 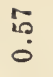 & $\overrightarrow{7}$ \\
\hline & 岁势 & $\begin{array}{l}\infty \\
\text { N } \\
\text { - }\end{array}$ & $\frac{O}{\mathbb{N}}$ & \&ँ & ஜூ & $\begin{array}{l}10 \\
10 \\
10\end{array}$ & $\begin{array}{l}\text { D } \\
\text { 10 }\end{array}$ & $\mathscr{8}$ & ํำ & 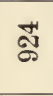 \\
\hline & 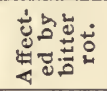 & $r$ & $\ddot{~}$ & $r$ & N & -1 & - & os & $\infty$ & -1 \\
\hline \multirow{3}{*}{ 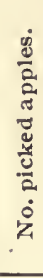 } & 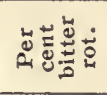 & $\vdots$ & లో & $\vdots$ & $\vdots$ & $\vdots$ & $\vdots$ & $\vdots$ & $\vdots$ & $\vdots$ \\
\hline & $\begin{array}{l}40 \\
0 \\
0 \\
\dot{0} \\
\dot{0}\end{array}$ & 占 & : & $\stackrel{D}{D}$ & సี & $\stackrel{10}{7}$ & $\underset{\text { ส }}{\infty}$ & 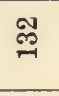 & $\stackrel{\varrho}{ٍ}$ & $\stackrel{\odot}{=}$ \\
\hline & 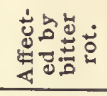 & $\vdots$ & -1 & $\vdots$ & $\vdots$ & $\vdots$ & $\vdots$ & $\vdots$ & $\vdots$ & $\vdots$ \\
\hline \multirow{3}{*}{ 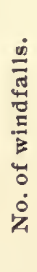 } & ن. & $\stackrel{9}{+}$ & $\frac{10}{5}$ & $\stackrel{m}{7}$ & ஜே. & : & $\stackrel{\leftarrow}{\circ}$ & $\stackrel{8}{:}$ & $\stackrel{N}{i:}$ & $\stackrel{4}{0}$ \\
\hline & पे & 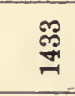 & 范 & $\infty^{\infty}$ & $\overrightarrow{8}$ & 융 & $\vec{F}$ & 跑 & $\bar{z}$ & 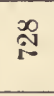 \\
\hline & 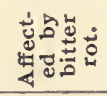 & $r$ & $\stackrel{100}{\pi}$ & - & v & -1 & - & 20 & $\infty$ & $\neg$ \\
\hline & 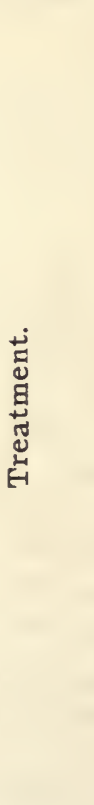 & 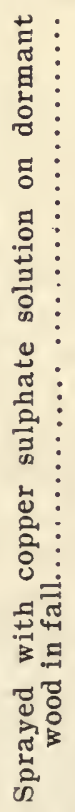 & 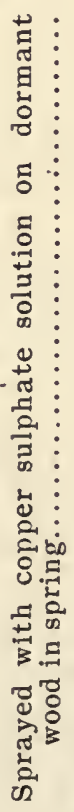 & 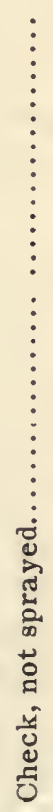 & 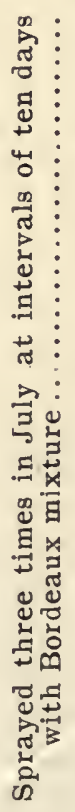 & 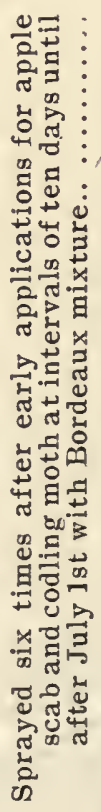 & 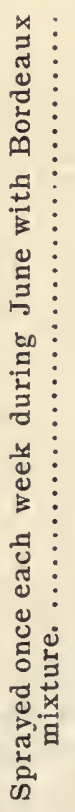 & 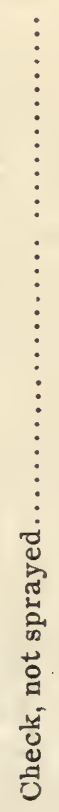 & 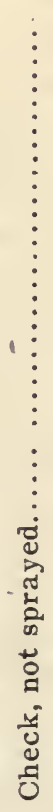 & 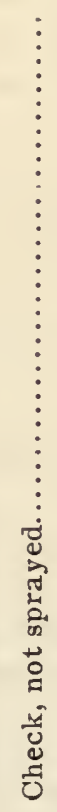 \\
\hline & $\begin{array}{l}\text { 岁茾 } \\
\dot{0} \\
\dot{2}\end{array}$ & & $\exists$ & $\Xi$ & 1 & & 5 & $\stackrel{5}{5}$ & 志 & 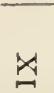 \\
\hline
\end{tabular}


190\%.] Bitter Rot of Apples, Horticultural Investigations. 503

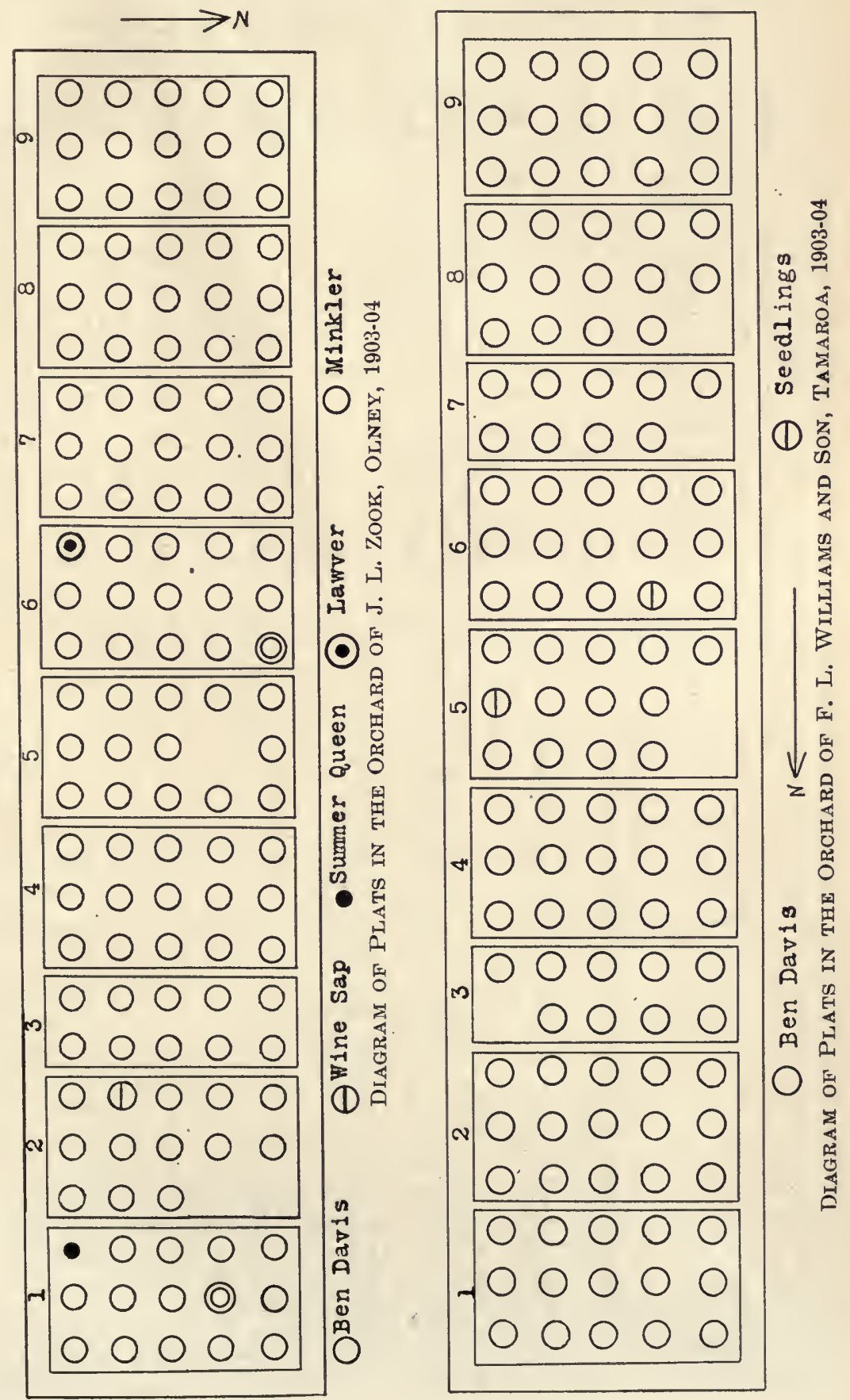




\begin{tabular}{|c|c|c|c|c|c|c|c|c|c|c|}
\hline \multirow{3}{*}{$\begin{array}{l}\frac{\dot{\omega}}{\tilde{J}} \\
\dot{0} \\
\dot{H}\end{array}$} & 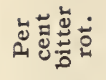 & î & $\begin{array}{l}\infty \\
\stackrel{\infty}{-1} \\
\end{array}$ & 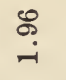 & $\stackrel{8}{+4}$ & $\stackrel{0}{\stackrel{0}{0}}$ & :ें & $\stackrel{\vec{N}}{a}$ & $\dot{\sigma}$ & $\begin{array}{l}0 \\
0 \\
0\end{array}$ \\
\hline & 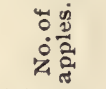 & 곰 & $\ddot{\&}$ & $\stackrel{\infty}{\infty}$ & 点 & $\stackrel{\mathscr{D}}{\stackrel{్}{~}}$ & $\stackrel{2}{8}$ & 䒢 & $\stackrel{\infty}{\circ}$ & $\stackrel{\circ}{\circ}$ \\
\hline & 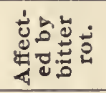 & $\stackrel{\Re}{\longrightarrow}$ & $\stackrel{\infty}{\rightarrow-1}$ & $\approx$ & 18 & $N$ & ్ㅣ & $\stackrel{\sim}{\sim}$ & 으 & $\infty$ \\
\hline \multirow{3}{*}{ 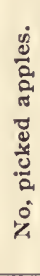 } & 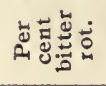 & के & ๙ึ. & 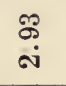 & ने & $\vdots$ & : & $\vdots$ & $\stackrel{8}{\infty}$ & กै \\
\hline & 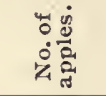 & 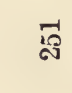 & है & 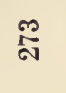 & 导 & 战 & 占 & $\bar{F}$ & ถี่ & है \\
\hline & 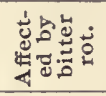 & $\infty$ & $\infty$ & $\infty$ & $\Rightarrow$ & : & & $\vdots$ & N & -1 \\
\hline \multirow{3}{*}{ 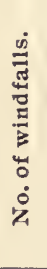 } & 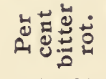 & 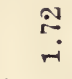 & ז̊ & تृ. & to & ஸ़ & $\stackrel{\infty}{\infty}$ & $\begin{array}{l}\hat{\infty} \\
\hat{0} \\
\hat{j}\end{array}$ & $\begin{array}{l}+ \\
0 \\
0\end{array}$ & $\begin{array}{l}\infty \\
0 \\
0\end{array}$ \\
\hline & 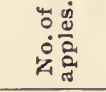 & శ్ & ชี่ & 聇 & $\vec{\infty}$ & 苍 & $\stackrel{\mathscr{ٌ}}{\stackrel{-}{\circ}}$ & 瓷。 & 怘 & $\begin{array}{l}\infty \\
\infty\end{array}$ \\
\hline & 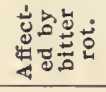 & סمג & 윽 & 0 & 落 & ov & బ్ల & $\stackrel{N}{\sim}$ & $\infty$ & $r$ \\
\hline & 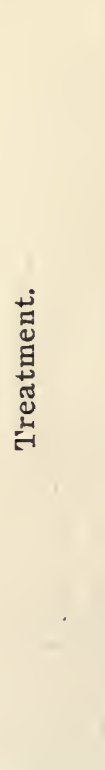 & 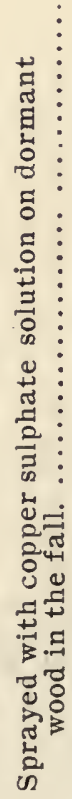 & 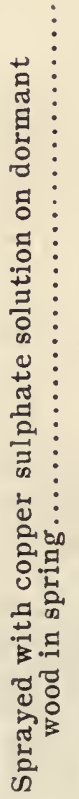 & 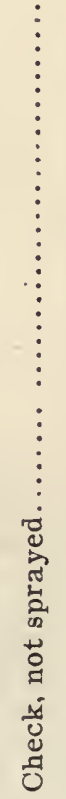 & 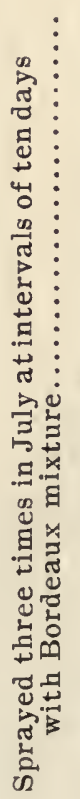 & 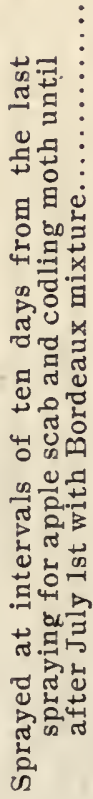 & 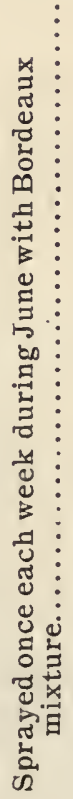 & 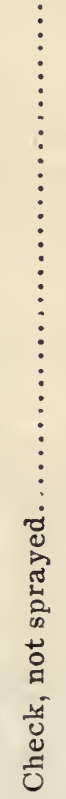 & 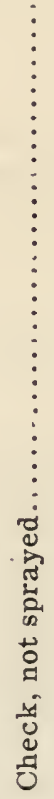 & 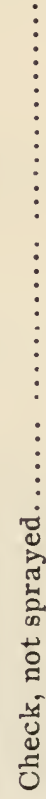 \\
\hline & ن & 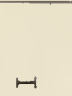 & $\Xi$ & $\exists$ & $i$ & $>$ & 5 & $\stackrel{\Xi}{5}$ & $\Xi$ & $\underline{3}$ \\
\hline
\end{tabular}


Orchard of J. W. Heaton, New Burnside, Johnson County, 1903

Experiments in the New Burnside orchard were not begun until after the owner had applied the early sprayings for apple scab and codling moth. The block of trees used was of the Ben Davis variety. The trees were divided into three plats of ten trees each. Rot was discovered June $25^{\text {th }}$ on an Early Harvest tree but did not occur on the Ben Davis variety until September 7 th. The windfalls were gathered and examined September 7 th, I8th, and October 6 th. The fruit was picked from the trees and the records completed October 6th. The plats were treated as follows:

Plat I-Check plat, received only the early sprayings for apple scab and codling moth.

Plat II-Sprayed once with Bordeaux mixture, June 24th, before the disease appeared, in addition to the early spraying for scab and codling moth.

Plat III-Sprayed once with Bordeaux mixture after the disease appeared, in addition to the early treatment for scab and codling moth.

In this orchard again very little bitter rot appeared and the results from all plats were so similar as to afford no conclusive data.

Tabie I I gives the data recorded in the New Burnside orchard.

\section{Orchard of Charles Alifin, Carbondale, Jackson County,} I9O3

This orchard, like the one at New Burnside, was secured after the early sprayings for apple scab and codling moth had been completed. Three plats of ten trees each were laid out in a block of Ben Davis trees. The treatment of the plats was as follows:

Plat I-Received only the early applications for apple scab and codling moth.

Plat II-Sprayed once with Bordeaux mixture, June 27th, before bitter rot appeared in addition to the early sprayings for apple scab and codling moth.

Plat III-Sprayed once with Bordeaux mixture, August I7th, after the disease appeared.

Bitter rot was first discovered on August I 7 th, the date of the spraying of Plat III. The fallen apples were gathered September $5_{\text {th }}$ and Igth, and the crop was picked from the trees on the latter date.

Here again the amount of bitter rot was small, though slightly greater than in the Olney, Tamaroa, and New Burnside orchards. It would not be safe to draw conclusions from the results of this experiment but there is a pretty strong indication that one spraying 
either shortly before or immediately after the appearance of the disease is entirely ineffectual in controlling the disease.

The results of the experiment in the Charles Allen orchard are given in Table 12.

Orchard of H. E. Allen, Carbondale, Jackson

County, 1903

The only orchard to furnish decisive data during the season of 1903 was that of Mr. H. E. Allen, near Carbondale. Bitter rot developed severely in this orchard and some valuable information was obtained through the experiments conducted therein. The block of trees in this orchard consisted of Jonathan, Winesap, and Ben Davis vareties. Spraying for scab and codling moth had been accomplished before the Department began work. Three plats of ten trees each were laid out, each plat containing several trees of each variety mentioned above. The plats received applications of spray as follows, p. 509. 
190\%.] Bitter Rot of Apples, Horticultural Investigations. 507
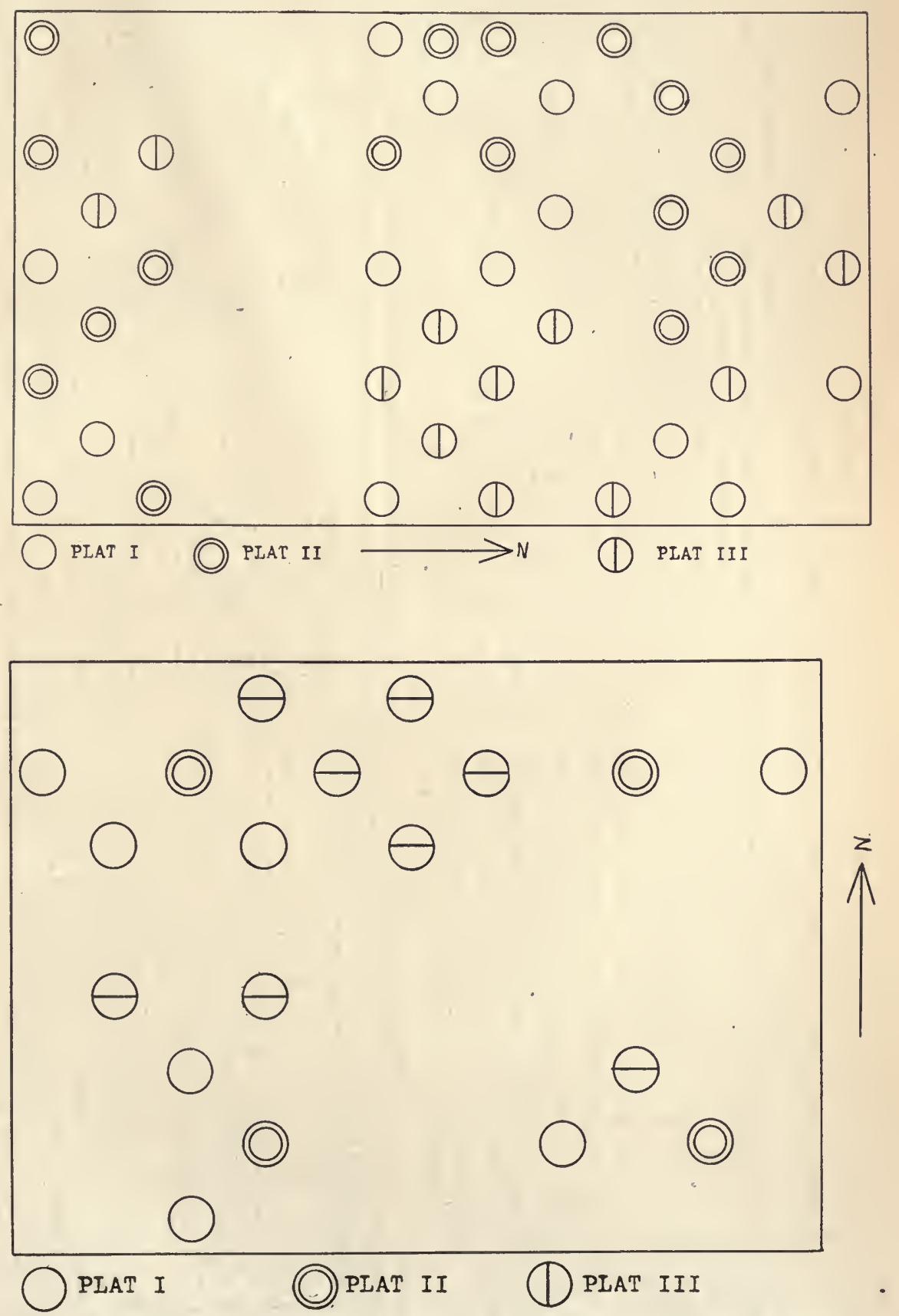

Diagram of Plats in the Orchard of J. W. Heaton, New Burnside, 1903 

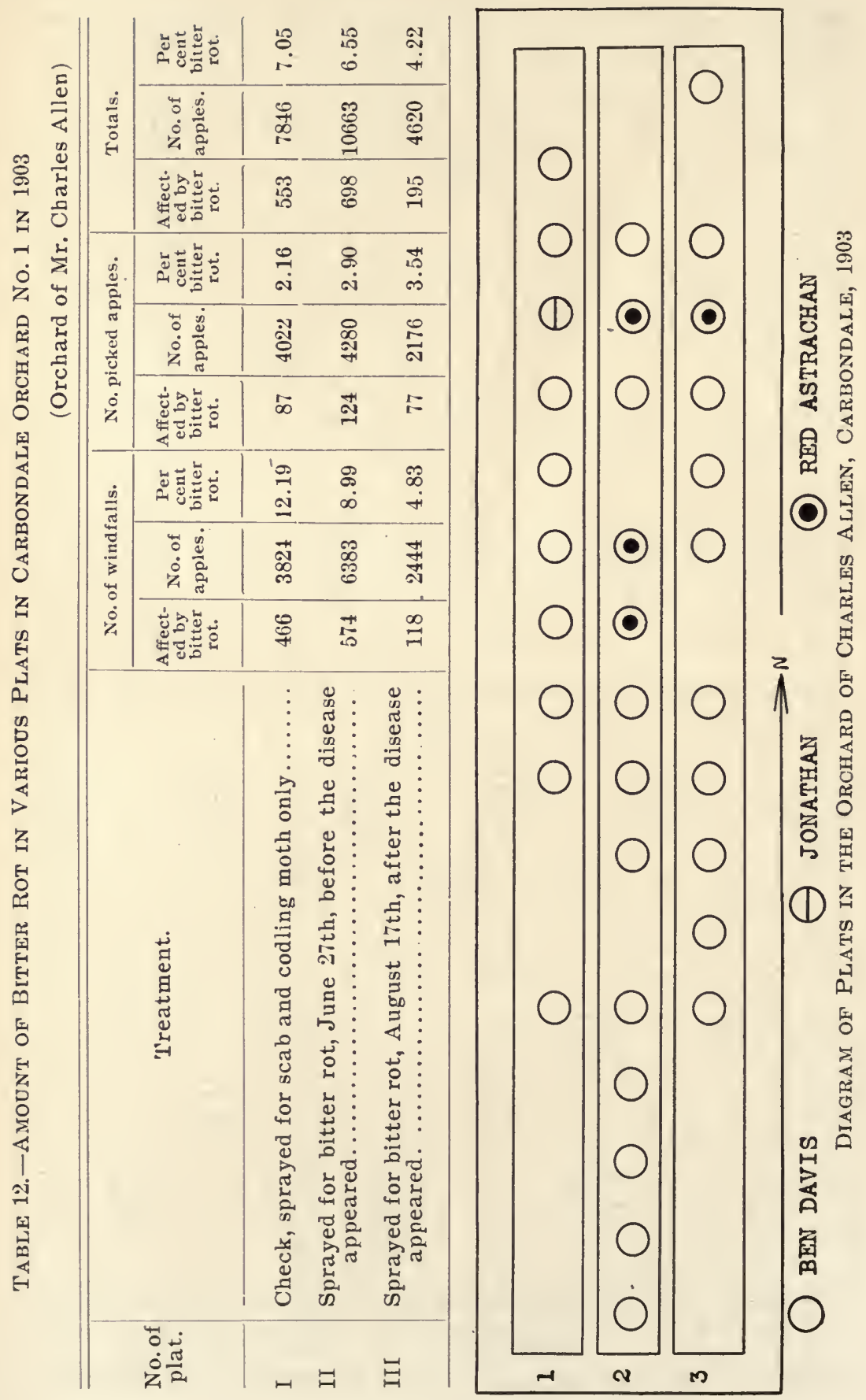


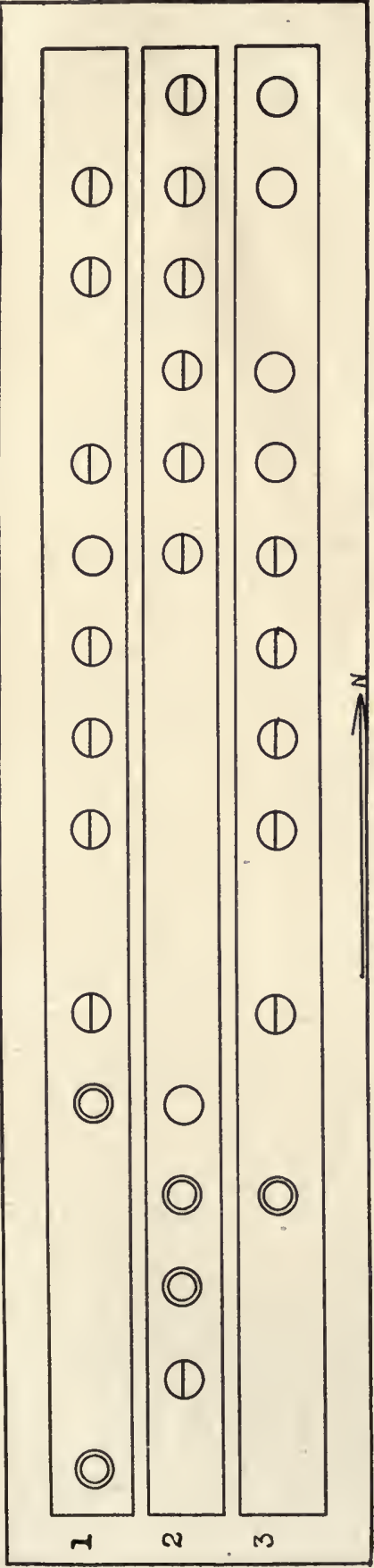

Plat I-Received only the early sprayings for scab and bitter rot.

Plat II - Sprayed with Bordeaux mixture for bitter rot, June 26 th and July ist, 号 before the disease appeared.

Plat III_Sprayed twice with Bordeaux mixture for bitter rot after the disease appeared, i. e., August 5th and 6 th.

Bitter rot first appeared August 5th. Records were made on the fallen apples August I 5th, I 7 th, 28th, September $5^{\text {th }}$ and 18 th. The Jonathans were picked from the trees September $5^{\text {th }}$ and the Ben Davis and Winesaps September 2 Ist. In Table 13 the different varieties are given separately.

In order that the comparisons between the treatments may be made more readily, the percentages of the fruit liable to bitter rot saved by the early spraying as compared with the late spraying and check plats are given in Table I 4, p. 5 II. 


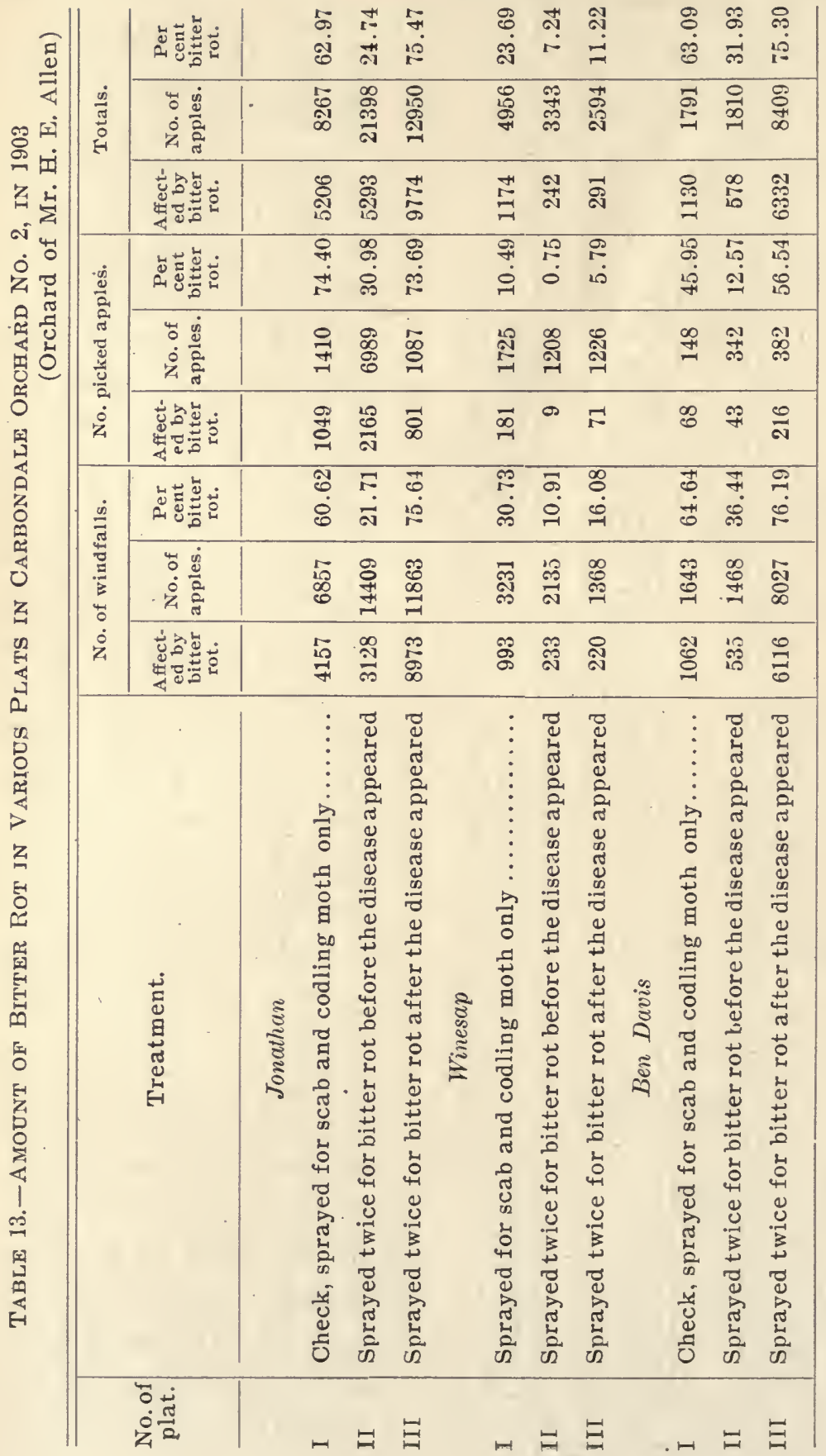


Table 14.-Saving EFFeCted by Two EARLy Sprayings For BitTer Rot Over Other Plats in Orchard of Mr. H. E. Allen

\begin{tabular}{|c|c|c|c|}
\hline $\begin{array}{l}\text { No. of } \\
\text { plat. }\end{array}$ & Treatment. & $\begin{array}{l}\text { Saving } \\
\text { over } \\
\text { plat III. }\end{array}$ & $\begin{array}{l}\text { Saving } \\
\text { ovèr } \\
\text { check } \\
\quad \text { I. }\end{array}$ \\
\hline . & Jonathan & & \\
\hline II & $\begin{array}{c}\text { Sprayed twice for bitter rot before disease } \\
\text { appeared } \ldots \ldots \ldots \ldots \ldots \ldots \ldots \ldots \ldots \ldots \ldots \ldots \ldots \ldots \ldots \\
\text { Winesap }\end{array}$ & 67.19 & 60.71 \\
\hline II & $\begin{array}{c}\text { Sprayed twice for bitter rot before disease } \\
\text { appeared ................................. } \\
\text { Ben Davis }\end{array}$ & 35.47 & 69.44 \\
\hline II & $\begin{array}{l}\text { Sprayed } t \text { wice for bitter rot before disease } \\
\text { appeared. } . \ldots \ldots \ldots \ldots \ldots \ldots \ldots \ldots \ldots \ldots \ldots\end{array}$ & 57.60 & 49.39 \\
\hline
\end{tabular}

A study of the two preceding tables shows at once the severely infected character of the fruit in this orchard, as much as 75 percent of the crop being infected in some of the plats. The Winesap variety proved to be less subject to the disease than the Jonathan and Ben Davis, each of these two kinds being about equally attacked by bitter rot. None of the treatments given was wholly successful in combating the disease. In fact, in the case of Jonathan and Ben Davis apples, the crop on the plats sprayed after the appearance of the rot showed a higher percentage of diseased fruit than that on the check plat. In both cases the infection is so much higher as to lead to a suspicion that the operation of spraying had aided.in spreading the disease rather than in suppressing it, though it is possible that there may have been enough more sources of infection among some of the trees in the late sprayed plats to account for the difference. In the Winesap plat, however, the late spraying appeared to reduce the rot considerably, and hence it would hardly be safe to assume that the bitter rot was disseminated in any degree by the spray applied to the late sprayed Jonathan and Ben Davis trees. Very marked and encouraging results were obtained by the two sprayings with Bordeaux mixture shortly before the appearance of the rot, 60.7 I percent of all the Jonathans liable to attack, as shown by the infection of the check plat, 69.44 percent of the Winesaps, and 49.39 percent of the Ben Davis being saved by these two applications. These results corroborate in a very significant manner those obtained in 1902 in the Tonti orchard where the plats sprayed a number of times before the appearance of the disease showed a better degree of control than those sprayed later. 


\section{CONCLUSIONS FOR I9O3}

This year's work proved so inconclusive in all the orchards, except that of Mr. H. E. Allen of Carbondale, that the results are not brought together into one tabulation as was done with the results of the work in 1902 . The following points are the only ones that seem to warrant the making of definite statements.

I. Spraying with Bordeaux mixture before the appearance of the disease again proved more effective in combating the disease than spraying after the infection had occurred.

2. One spraying either before or after the appearance of the rot did not appreciably reduce the destructiveness of the disease.

3. Two sprayings before the appearance of the rot were insufficient to control the disease completely but did reduce it by about one-half.

4. To prevent the damage which may be caused by bitter rot, it is necessary to have the fruit thoroughly coated with Bordeaux mixture before the disease breaks out.

The following problems, the solutions of which were undertaken in 1903 , were left unsolved or partially so:

I. Will spraying dormant wood in the fall with copper sulphate solution prevent the disease?

2. Will spraying dormant wood in the spring with copper sulphate solution prevent the disease?

3. Will spraying three times in July with Bordeaux mixture prevent the disease?

4. Will spraying with Bordeaux mixture at intervals of ten days after the first three sprayings until after July ist prevent the disease?

\section{4}

Experiments were continued in the Flora, Olney, and Tamaroa orchards and installed in an orchard near Kell during the season of I904. This season proved again unfavorable to the development of the disease, its distribution over the state and among the plats and trees in individual orchards being most uneven. As in the preceding season only one orchard, that near Kell, gave uniform results and evidenced anything like a uniform infection of the rot. 'The same plan of experiments was followed as in 1903, except in the case of Plat I, where the fall treatment using copper sulphate solution on the dormant wood was replaced with a treatment using Oregon Wash applied to the dormant wood in the spring. 


\section{Orchard of Dale Mann, Flora, Clay County, igo4}

Nine plats consisting mostly of trees of the Willow Twig variety were laid out in an orchard at Flora. The plats comprised from ten to fifteen trees each, in all, one hundred and twenty-five trees. The orchard was sprayed three times early in the season for apple scab, codling moth, and canker worm, the applications being made April I6th, May I 3 th, and May 2oth. All plats received these three sprayings, and the treatments given subsequently were as follows:

Plat I-Sprayed March 29th with Oregon Wash.

Plat II-Sprayed March 29th with copper sulphate solution, one pound of copper sulphate to fifteen gallons of water.

Plat III-Check plat, no applications made after the three early sprayings above referred to.

Plat IV-Sprayed with Bordeaux-Paris green mixture three times at intervals of ten days beginning on or about July Ist. The applications were made July 9th, I9th, and 29 th.

Plat $V$.- Sprayed with Bordeaux mixture about every ten days after the early spraying for apple scab and codling moth, until after July Ist. The applications were made May 3oth, June 8th, 2oth, 29th, and July 9 th.

Plat VI-Sprayed four times with Bordeaux mixture as follows: June 8th, I 5th, 20th, and 29th.

Plat VII-Check plat, no applications made after the three early sprayings above referred to.

Plat VIII-Sprayed when bitter rot first appeared until the fruit was thoroughly coated with Bordeaux mixture.

Plat IX-Check plat, no applications made after the three early sprayings above referred to.

The fallen apples were gathered August Ioth, 29th, September 8th, 3 Ist, and October 28 th, and the fruit was picked from the trees on the date last mentioned, October 28 th. The data are found in Table I 5 .

The amount of bitter rot on the various check plats was very inconstant, Plat III having only 1.87 percent and Plats VII and IX having I9.28 percent and 5.70 percent, respectively. Plat III, however, produced only a very light crop of apples as compared with Plats VII and IX and appears to have been under exceptional conditions. Comparing the sprayed plats with check Plats VII and IX there is a marked advantage in favor of all the treated plats. No one of the treated plats showed any marked superiority over the others, but the plat sprayed with Oregon Wash on dormant wood in the spring showed a much higher percentage of bitter rot than did any other of the treated plats, and almost as high a percentage as check Plat IX. Owing, however, to the irregularity of the results in the check plats it seems unsafe to say just how much of the apparent 


\begin{tabular}{|c|c|c|c|c|c|c|c|c|c|c|}
\hline & 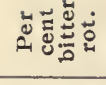 & تั & $\stackrel{\infty}{\stackrel{\sim}{\sim}}$ & $\stackrel{\sim}{\infty}$ & नें & نْ & $\stackrel{\oiiint}{\infty}$ & 品 & $\begin{array}{l}\stackrel{0}{0} \\
\dot{\text { i }}\end{array}$ & is \\
\hline & 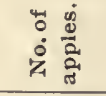 & స్ఞ & 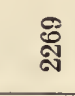 & రే & 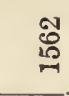 & - & 令 & เి & $\underset{0}{\infty}$ & ثี \\
\hline & 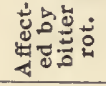 & $\underset{\sim}{\vec{~}}$ & శి & $\stackrel{\leftrightarrow}{\sim}$ & $\overrightarrow{\mathrm{N}}$ & คั & $\not{7}$ & $\stackrel{10}{7}$ & . & $\Xi$ \\
\hline \multirow{3}{*}{ 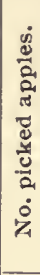 } & 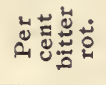 & $\stackrel{尺}{\stackrel{N}{*}}$ & مْ & 品 & $\stackrel{8}{\circ}$ & $\begin{array}{l}115 \\
0 \\
0\end{array}$ & के & 今े & $\begin{array}{l}0 \\
0\end{array}$ & 우 \\
\hline & $\begin{array}{l}\text { पे } \\
\dot{0} \\
\dot{0} \\
\dot{0}\end{array}$ & $\begin{array}{l}\text { สิ } \\
\text { ờ }\end{array}$ & 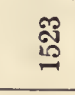 & กิง & 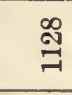 & ठิ & 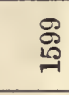 & 孛 & $\stackrel{\infty}{0}$ & జొఞ \\
\hline & 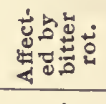 & $\Re$ & $\infty$ & N & -1 & 0 & $\overline{\mathrm{N}}$ & 10 & $\stackrel{ }{-1}$ & ภิ \\
\hline \multirow{3}{*}{ 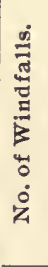 } & ن & भ̊ & $\begin{array}{l}\text { W } \\
\text { ஸे }\end{array}$ & $\begin{array}{l}8 \\
\dot{\pi}\end{array}$ & ¿' & $\stackrel{\sharp}{\rightleftarrows}$ & $\begin{array}{l}\infty \\
\infty \\
\dot{N}\end{array}$ & 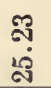 & $\stackrel{\sharp}{\sharp}$ & $\stackrel{2}{\infty}$ \\
\hline & $\begin{array}{l}\text { पे } \\
\dot{0} \\
\dot{0} \\
\dot{z}\end{array}$ & $\stackrel{8}{\circ}$ & I & 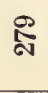 & 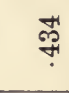 & $\mathscr{\mathscr { O }}$ & ஜீ & ผู & $\underset{7}{\stackrel{8}{-1}}$ & $\exists$ \\
\hline & 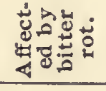 & $\stackrel{\infty}{\infty}$ & $\overrightarrow{\mathrm{N}}$ & $\stackrel{m}{\rightarrow}$ & ్ & สิ & ตึ & 윽 & $\stackrel{\infty}{\not}$ & $\vec{\sigma}$ \\
\hline \multicolumn{2}{|r|}{ 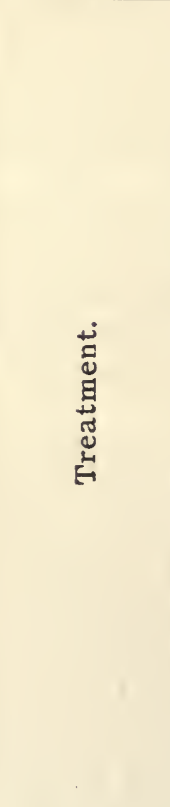 } & 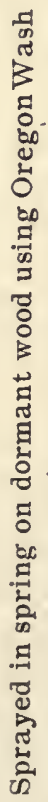 & 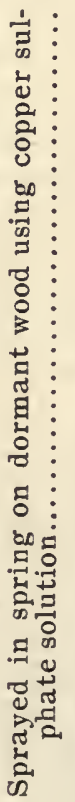 & 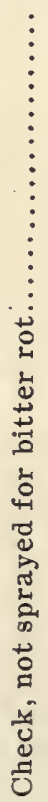 & 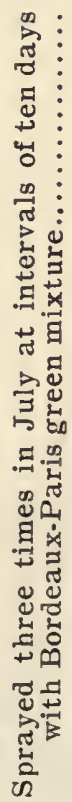 & 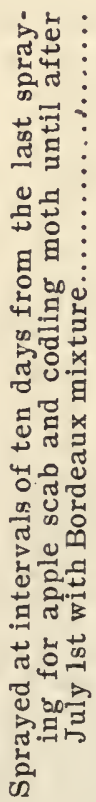 & 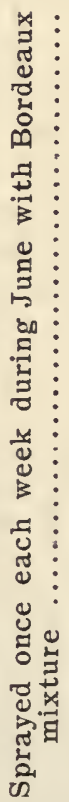 & 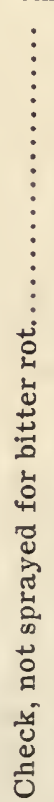 & 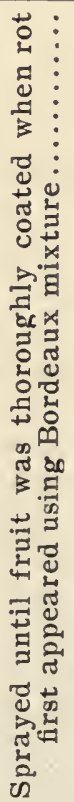 & 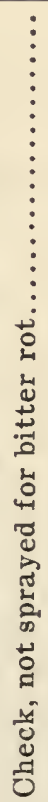 \\
\hline & पे & $\mapsto$ & ઘ & છ & $\vec{w}$ & $>$ & $\stackrel{5}{5}$ & 号 & 志 & $\stackrel{\perp}{A}$ \\
\hline
\end{tabular}




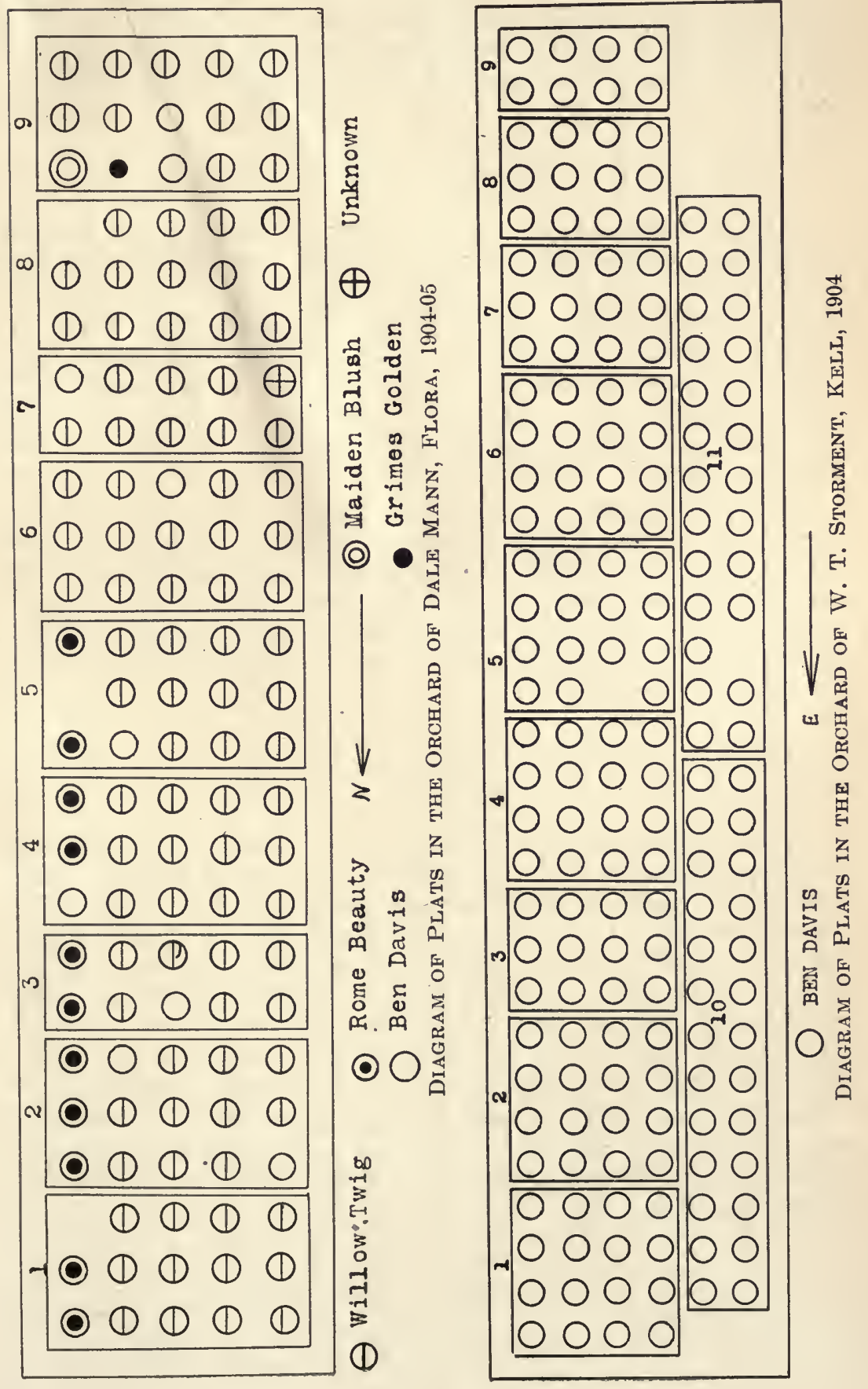


protection afforded the treated plats was due to spray and how much was due to advantages in circumstances of infection. The results of the experiment are, therefore, suggestive rather than conclusive.

\section{Orchard of J. L. Zook, Olnety, Richland County, I904}

The experimental plats in this orchard consisted, as in the case of the Flora orchard, of nine plats of fifteen trees each. (For plan of plats see p. 503.) The variety was Ben Davis and the treatments given each plat were identical with those given in the Flora orchard. Bitter rot appeared in this orchard July 27 th. Records were made on the fallen apples on July 12th, August 12th, I7th, 26th, September 7th, I5th, 24th, 30th, and October 2oth. The crop was picked from the trees October 20 th and 2 Ist and the data compiled in Table I6, p. 5 I 7 .

None of the plats in this orchard showed any serious development of the disease. The percentage of bitter rot, however, runs uniformly less throughout all plats sprayed with Bordeaux mixture than through the check plats and the plats which were treated with Oregon Wash and copper sulphate on the dormant wood early in the spring. Here again the results are suggestive, but not marked enough to be conclusive.

Orchard of F. L. Wimitiams \& Son, Tamaroa, Perry County, 1904

In this orchard the same schedule of treatments was given as in the Flora and Olney orchards, except in the case of Plat IX, which was sprayed with Bordeaux mixture until the fruit was thoroughly coated after the rot had become well established. (For plan of plats see p. 503.) The dates of spraying were nearly the same, varying only a day or so for corresponding applications. The check plats consisted of ten trees each and all other plats of fifteen trees each. The variety was Ben Davis. Bitter rot first appeared July I6th. The fallen fruit was gathered on August Ist and 2d, 9th and Ioth, I 7 th, 25th, September $2 \mathrm{~d}$ and 3d, I5th and I6th, 27th and 28th, and October 26th and 3 Ist. The crop was picked from the trees October 27 th, 28th, and 29th. The data secured are tabulated in Table I7, p. 5 I 8 . 
190\%.] Bitter Rot of Apples, Horticultural Investigations. 517

\begin{tabular}{|c|c|c|c|c|c|c|c|c|c|c|}
\hline \multirow{3}{*}{$\begin{array}{l}\stackrel{\dot{n}}{\pi} \\
\text { 苛 } \\
\dot{H}\end{array}$} & نَ & 0 & $\stackrel{-1}{6}$ & $\stackrel{0}{-1}$ & $\stackrel{2}{?}$ & '0 & $\stackrel{0}{\ddot{0}}$ & م. & ث. & $\begin{array}{l}\text { లे } \\
0\end{array}$ \\
\hline & 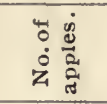 & ำ & 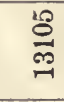 & $\begin{array}{l}\stackrel{0}{11} \\
\text { ठै }\end{array}$ & 10 & $\begin{array}{l}1 \\
\infty \\
1 \\
0 \\
0\end{array}$ & ت્] & $\begin{array}{l}\mathscr{0} \\
: 0 \\
\infty\end{array}$ & के & 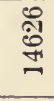 \\
\hline & 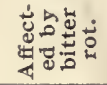 & $\varnothing$ & $\frac{\mathscr{P}}{\mathrm{N}}$ & $\underset{\sim}{\mathbb{N}}$ & $\mathbb{Z}$ & $r$ & $\bar{T}$ & ฟ้ & ลิ & ใิ \\
\hline \multirow{3}{*}{ 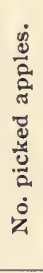 } & 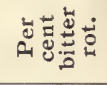 & $\begin{array}{l}8 \\
0\end{array}$ & $\stackrel{180}{0}$ & $\stackrel{9}{\stackrel{+}{0}}$ & $\stackrel{8}{\circ}$ & $\vdots$ & $\begin{array}{l}+1 \\
0\end{array}$ & $\stackrel{5}{\circ}$ & : & $\stackrel{10}{:}$ \\
\hline & 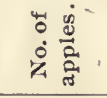 & 10 & $\begin{array}{l}0 \\
80 \\
80\end{array}$ & 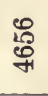 & $\begin{array}{l}10 \\
10 \\
10\end{array}$ & ซึ & कึ. & 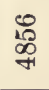 & 葛 & 祳 \\
\hline & 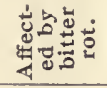 & ๓ & $\mathscr{F}$ & คึ & N & : & ov & กิ & : & $\Rightarrow$ \\
\hline \multirow{3}{*}{ 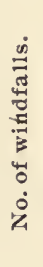 } & 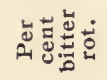 & $\stackrel{8}{8}$ & $\begin{array}{l}\mathscr{0} \\
\dot{0}\end{array}$ & i & :ึ & $\stackrel{9}{:}$ & 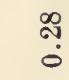 & 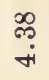 & : & 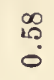 \\
\hline & 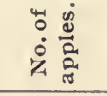 & 융 & 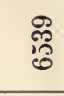 & ? & $\frac{N}{5}$ & $\begin{array}{l}0 \\
10 \\
10 \\
\text { in }\end{array}$ & $\begin{array}{l}10 \\
\text { พิ } \\
\text { กิ }\end{array}$ & 鬲 & 总 & : 옹 \\
\hline & 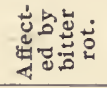 & $\approx$ & 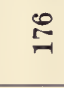 & ஓ & $\stackrel{\mathcal{I}}{\sim}$ & $r$ & $\stackrel{20}{7}$ & $\underset{\sim}{\mathbb{N}}$ & oิ & $\stackrel{9}{*}$ \\
\hline & 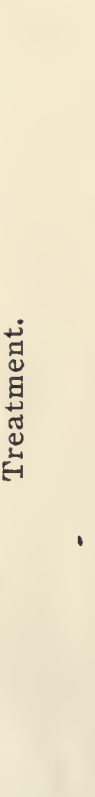 & 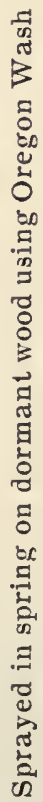 & 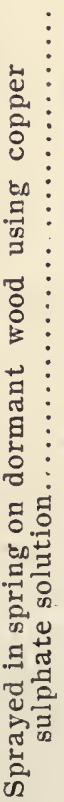 & 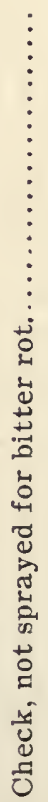 & 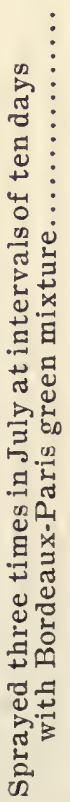 & 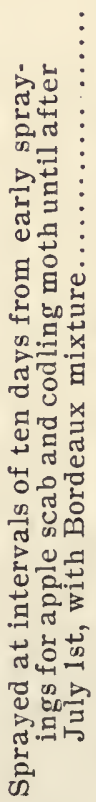 & 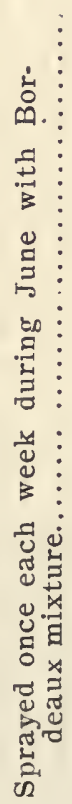 & 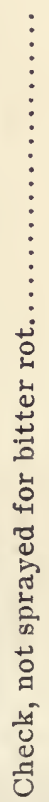 & 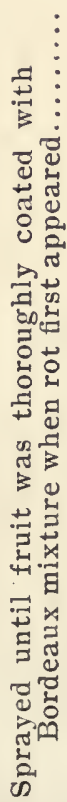 & 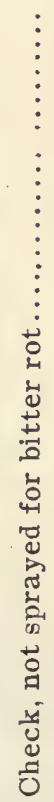 \\
\hline & 完 & 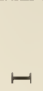 & ほ & છ & : & $p$ & $\mapsto$ & $\stackrel{\overrightarrow{7}}{\Rightarrow}$ & $\stackrel{\Xi}{\rightrightarrows !}$ & $\stackrel{\triangle A}{A}$ \\
\hline
\end{tabular}




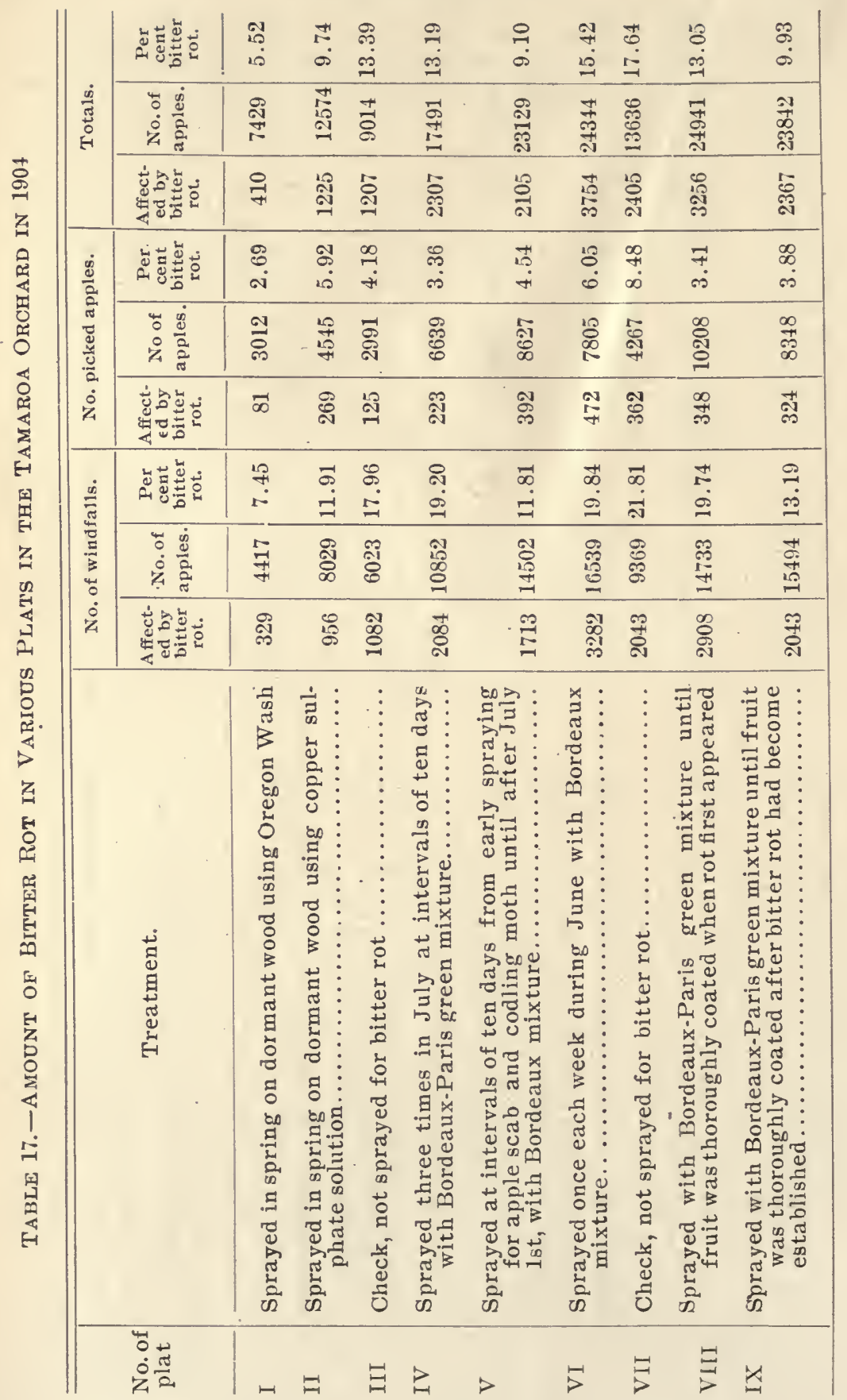


The data contained in Table I 7 are certainly confusing. The treatment with Oregon Wash, which in all other experiments had proven ineffective, appeared the most effective of any of the sprays applied. In the other plats spraying with Bordeaux mixture seemed to have only very slight effects upon the rot, the differences between the sprayed and the check plats being too small to warrant the drawing of any conclusions.

\section{Orchard of W. T. Storment, Keli, Marion County, 1904}

Nine plats of Ben Davis trees were selected in this orchard, each comprised of from eight to sixteen trees, most of them containing the latter number. The treatment was exactly similar to that given in the Williams orchard at Tamaroa, but late in the season two other plats were added to the experiment, these being designated Plats X and XI, and were treated as follows:

Plat X-Sprayed on July 29th with a solution of eight ounces of copper sulphate to fifty gallons of water.

Plat XI-Sprayed on July 29th with a solution of ten ounces of copper sulphate to fifty gallons of water.

Bitter rot was first observed in the plats of July 22d. The windfalls were gathered July 3oth, August 8th, I3th, 24th, September Ist, 8th, 22d, and October $3 \mathrm{~d}$. The fruit was harvested from October $3 \mathrm{~d}$ to 7 th. The results were then tabulated in Table-I8.

The most striking results of the season were secured in the orchard at Kell, but unfortunately the infection was light in the center of the orchard where plats V, VI, and VII were located, and the results possibly show a greater saving than would actually have occurred had the conditions of infection been different. However, the differences between the various treatments are sufficiently wide to warrant the drawing of some definite conclusions. In every instance spraying before the bitter rot appeared, Plats IV, V, and VI, gave almost perfect control of the disease; spraying after rot appeared greatly reduced the number of infected fruits but did not control the disease so perfectly as did the early spraying; treatment of the dormant wood gave no beneficial results as compared with the check plats, and a similar result followed the treatments with various strengths of copper sulphate solution which were given July 29th to Plats X and XI. Indeed the application of the pure copper sulphate caused considerable foliage injury and could not have been recommended even had the treatment been effective in controlling the disease.

As corroborative evidence the results of the work in the Kell orchard are most valuable. It will be remembered that all the data thus far obtained point strongly to the advisability of coating the fruit thoroughly with Bordeaux mixture before the first occurrence of bitter rot, as the safest and surest preventive of the disease. More- 


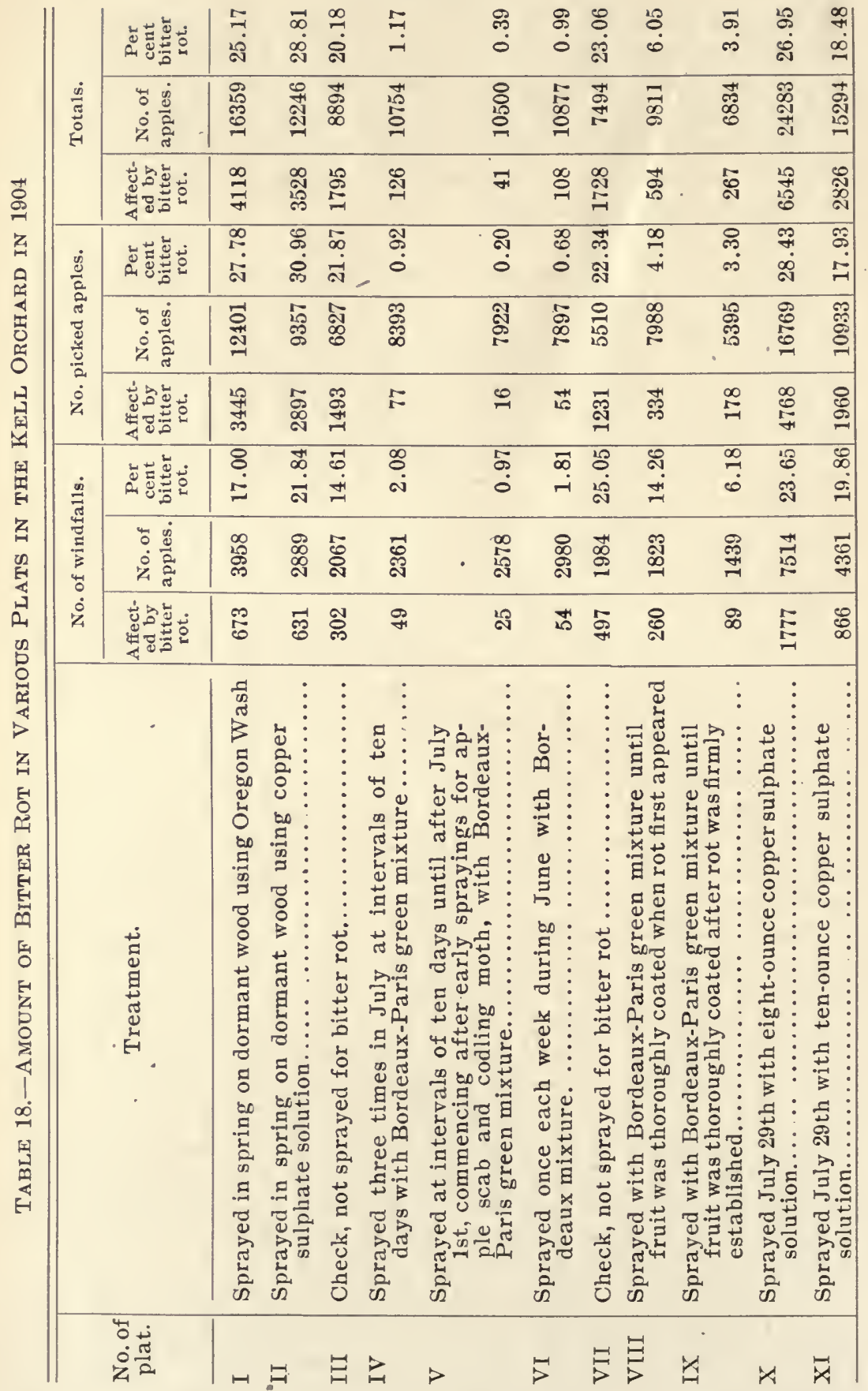


over it strongly corroborated the data showing the ineffectiveness of treatments of the dormant wood with Oregon Wash and copper sulphate solution, obtained in the Flora and Olney orchards, and indicates that the low percentage of bitter rot appearing in the Williams orchard at 'Tamaroa on the plat treated with Oregon Wash was due rather to lighter infection or to some other cause than to the treatment itself.

The following table shows the percentage saving of the total amount of infection, as shown by the check plats, of the various treatments over the checks. The average of the two check plats, III and VII, is taken as the standard of infection, though as a matter of fact higher infections appeared in three other plats, those in which the dormant wood was treated with Oregon Wash and copper sulphate solution, Plats I and II, and the plat which was sprayed with pure copper sulphate solution on July 29th, Plat X.

'Table 19.-Saving EfFected by Various Treatments in the Kell ORCHARD, 1904

\begin{tabular}{|c|c|c|}
\hline $\begin{array}{l}\text { No. of } \\
\text { plat. }\end{array}$ & Treatment. & $\begin{array}{l}\text { Saving } \\
\text { over } \\
\text { check } \\
\text { plats. }\end{array}$ \\
\hline IV & 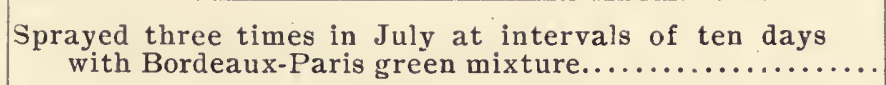 & $\begin{array}{l}\text { Per- } \\
\text { centage } \\
94.59\end{array}$ \\
\hline $\mathrm{V}$ & 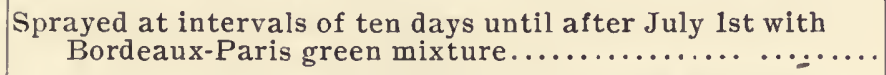 & 98.20 \\
\hline VI & $\begin{array}{l}\text { Sprayed once each week during June with Bordeaux. } \\
\text { Paris green mixture } \ldots \ldots \ldots \ldots \ldots \ldots \ldots \ldots \ldots \ldots \ldots \ldots \ldots \ldots\end{array}$ & 95.42 \\
\hline VIII & $\begin{array}{l}\text { Sprayed with Bordeaux-Paris green mixture until fruit } \\
\text { was thoroughly coated after rot first appeared................ }\end{array}$ & 72.02 \\
\hline IX & $\begin{array}{l}\text { Sprayed with Bordeaux-Paris green mixture until fruit } \\
\text { was thoroughly coated after rot had become established }\end{array}$ & 81.91 \\
\hline
\end{tabular}

From the above figures it appears that spraying with Bordeaux mixture three to five times before the appearance of the rot may control from 94.59 to 98.20 percent of the entire loss due to bitter rot.

Since the treatments in the various orchards during the year I904 are all similar, and since in drawing conclusions on experimental work of any kind it is well to employ the most available data, providing it has been gathered under equally good conditions of control, a summary of the results from the four orchards under observation is given below. For greater convenience in comparing the results the totals of all the check plats are given and placed at the head of the table; the other plats are numbered as in the case of the tables preceding, and a column is added showing the percentage gain of the various treated plats in cases where gains resulted. 


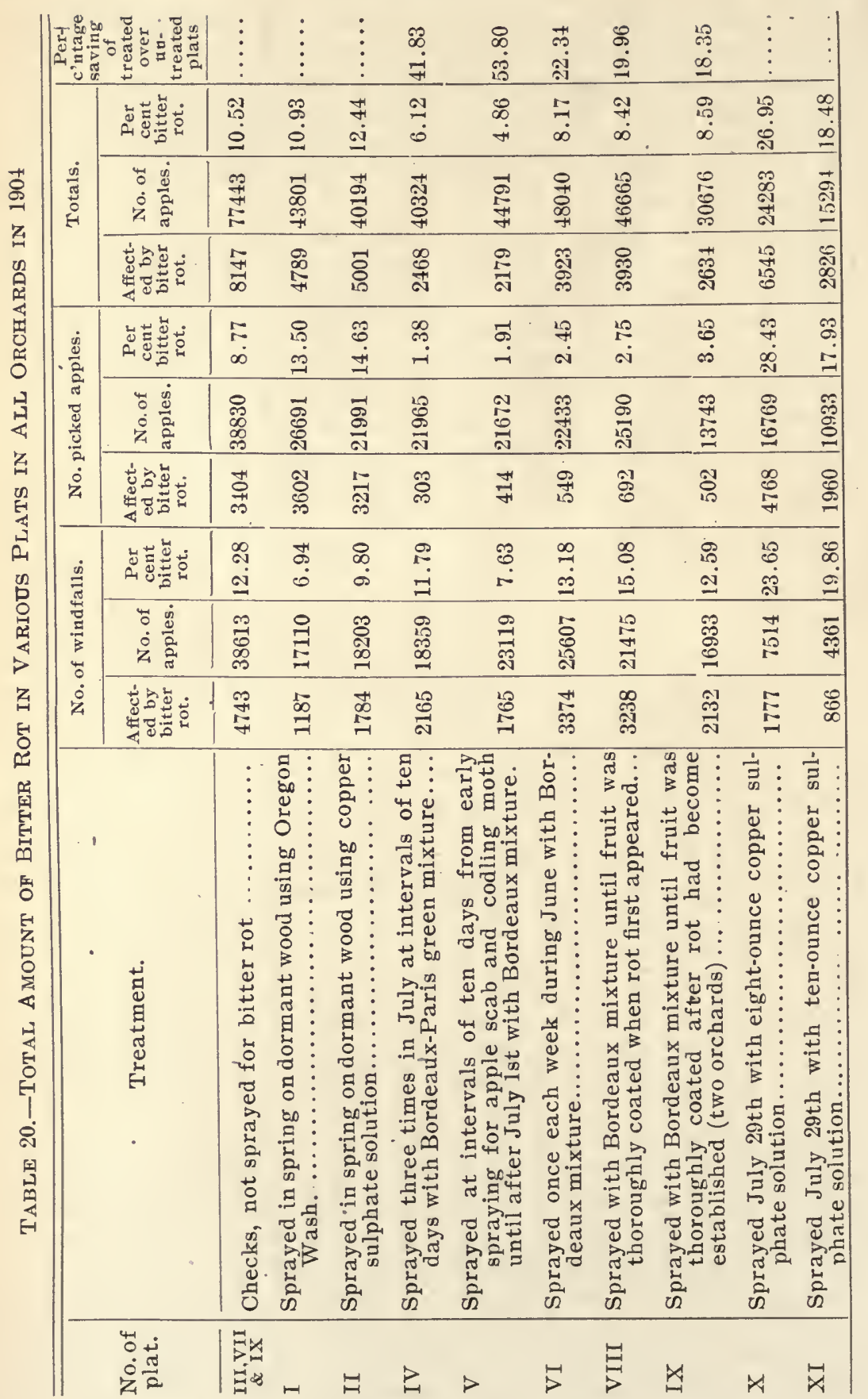




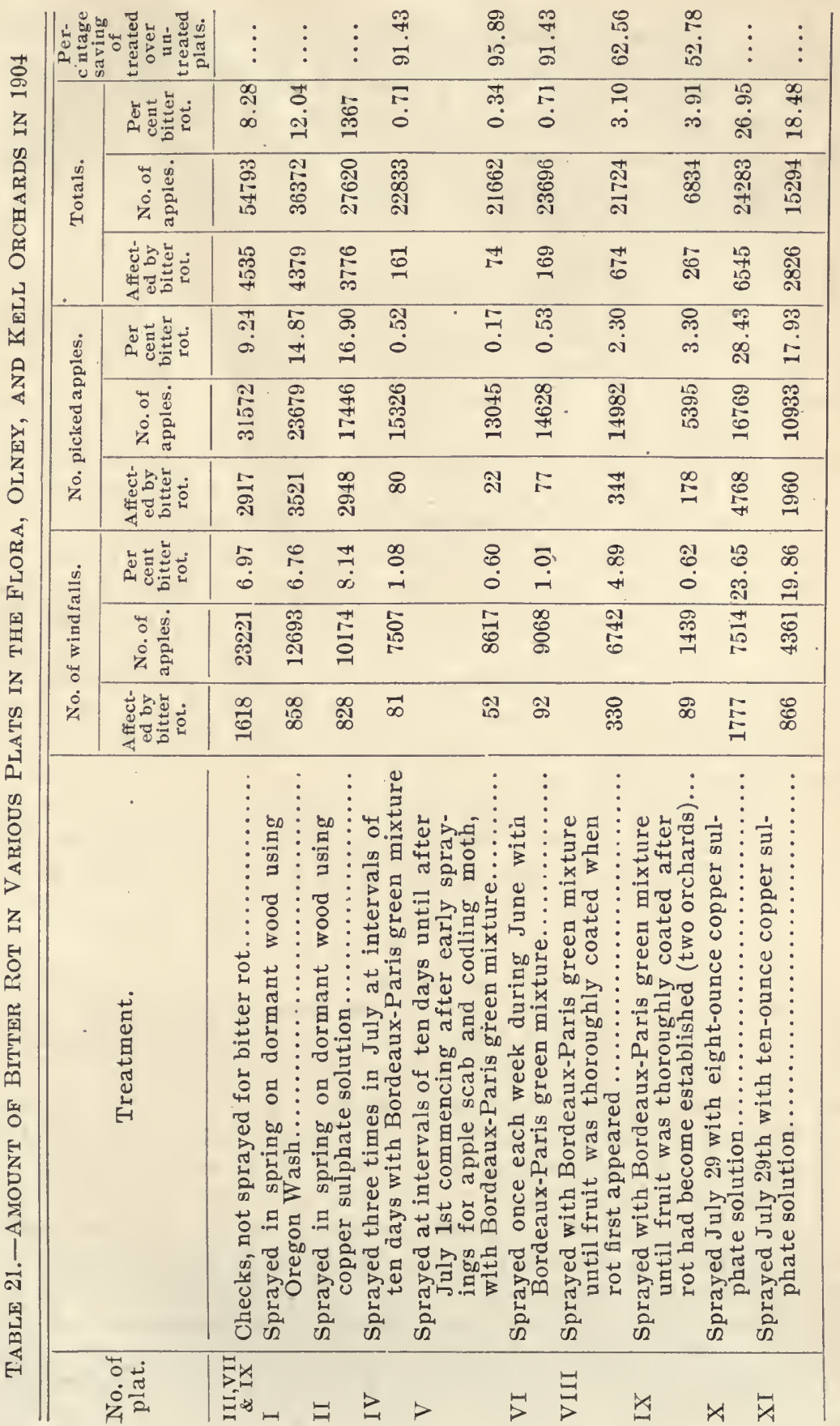


On account of the irregular character of the infection in the Tamaroa orchard in I904, a similar table has also been prepared giving a summary of the data obtained in the Flora, Olney, and Kell orchards alone, a table which the author believes to be more nearly an expression of the actual value of the spraying operations than Table 20, referred to in the preceding paragraphs.

The two tables are given on pp. $5^{22}$ and 523 .

\section{CONCLUSIONS FOR 1904}

I. Treatment of the dormant wood with either Oregon Wash or copper sulphate solution was entirely ineffectual in controlling bitter rot.

2. Spraying with Bordeaux mixture from three to five times at various intervals shortly before the appearance of the rot was by all means the most effective treatment in preventing the ravages of the disease, preventing from 41.83 percent to 53.80 percent of the entire loss due to bitter rot, when the results of the work in the fuur orchards are totaled. Leaving out the Tamaroa orchard, where the infection seemed to be very unequally distributed among the various plats, as already explained on p. 5r9, Plats IV, V, and VI, which were sprayed from three to five times before the appearance of the rot, gave the following percentages of saving over the check plats, respectively; Plat IV, 9 I.43 percent; Plat V, 95.89 percent; Plat VI, 9r.43 percent.

3. Spraying after the appearance of the disease with Bordeaux mixture effected a saving of 18 to 20 percent in all orchards, and of 52 to 63 percent in the three orchards at Flora, Olney, and Kell.

\section{5}

In 1905 it was decided, on account of the scarcity of bitter rot the year before, to abandon work in the Olney and Tamaroa orchards, selecting instead orchards that had a good crop with a plentiful supply of bitter rot the preceding year. The Mann orchard at Flora and the orchard of Mr. John Blackledge, of Clay City, were chosen for the purpose, and additional lines of inquiry were involved in the experiments for this season as follows: (I) the application of twenty-five pounds of salt on the ground under each tree of a plat; (2) spraying a plat with soluble Borcleaux mixture once each week during June; (3) spraying once only during early treatment for scab and codling moth; (4) spraying with dust spray; (5) spraying at intervals of ten days after the early sprayings for scab and codling moth with copper sulphate solutions of varying strengths; (6) omitting the early sprayings for scab and codling moth entirely.

Orchard of Dale Mann, Flora, Clay County, igo5

Nine plats were laid out in a block of Willow Twig apples, seven plats consisting of fifteen trees each, and two plats, those re- 
served as checks and given no treatment, of ten trees each, or, in all, one hundred and twenty-five trees. All of the plats received the first and third applications for scab and codling moth, the first spraying being given April 4th and 5th, before the blossoms opened, and the second May 8th, one week after the petals had fallen. The treatment for bitter rot consisted of applications of Bordeaux-Paris green mixture made up according to the standard formula, the same as used in previous seasons, four pounds of lime, four pounds copper sulphate, four ounces of Paris green, and fifty gallons of water. The exact treatment of each of the plats for bitter rot, that is the treatment following the two early sprayings for scab and codling moth, was as follows:

Plat I-Treated with 25 pounds salt distributed about each tree, May 27 th.

Plat II-Sprayed with soluble Bordeaux June 6th, I3th, 2oth and 27 th* $^{*}$.

Plat III-Not sprayed for bitter rot.

Plat IV-Sprayed with Bordeaux-Paris green mixture July 6th, I 5 th, and $25^{\text {th. }}$.

Plat $V$-Sprayed with Bordeaux-Paris green mixture May I8, June 6th, I 5 th, and $27^{\text {th. }}$.

Plat VI-Sprayed with Bordeaux-Paris green mixture June 6th, I3th, 2oth, and 27 th.

Plat VII-Not sprayed for bitter rot.

Plat VIII-Sprayed with Bordeaux-Paris green mixture three times, July $25^{\text {th }}$, when bitter rot was first discovered.

Plat IX-Not sprayed for bitter rot.

*Preparation of Soluble Bordeaux Mixture-The Soluble Bordeaux mixture used in this experiment was prepared according to a formula obtained from Professor S. M. Babcock of the University of Wisconsin, as follows:

\section{STOck Sor utrons}

1 - Copper Sulphate Solution:

Dissolve 1 pound of copper sulphate in 2 gallons of cold water,

2-Solution of sucrate of lime:

Slake 10 pounds of fresh lime through a wire strainer and add a solution of 25 pounds of granulated sugar in 50 pounds of water. Stir thoroughly at frequent intervals, and after two or three hours decant or siphon the clear liquid from the undissolved lime.

The quantities named are sufficient for about 8 gallons of standard solution of sucrate of lime.

\section{SPRAYING Sol,uTion}

Take equal parts of solutions 1 and 2 and add three parts of water. Agitate until the copper hydrate, which is at first precipitated, is entirely dissolved. Upon standing a slight deposit of gypsum is formed leaving a deep blue solution of hydrate of copper. If desired the spray may be applied immediately after preparation as the small amount of finely divided gypsum will not interfere with the operation. Prepared in this manner the solution contains about the same amount of copper hydrate as the ordinary Bordeaux mixture. It may be diluted indefinitely with water without a precipitate forming. 


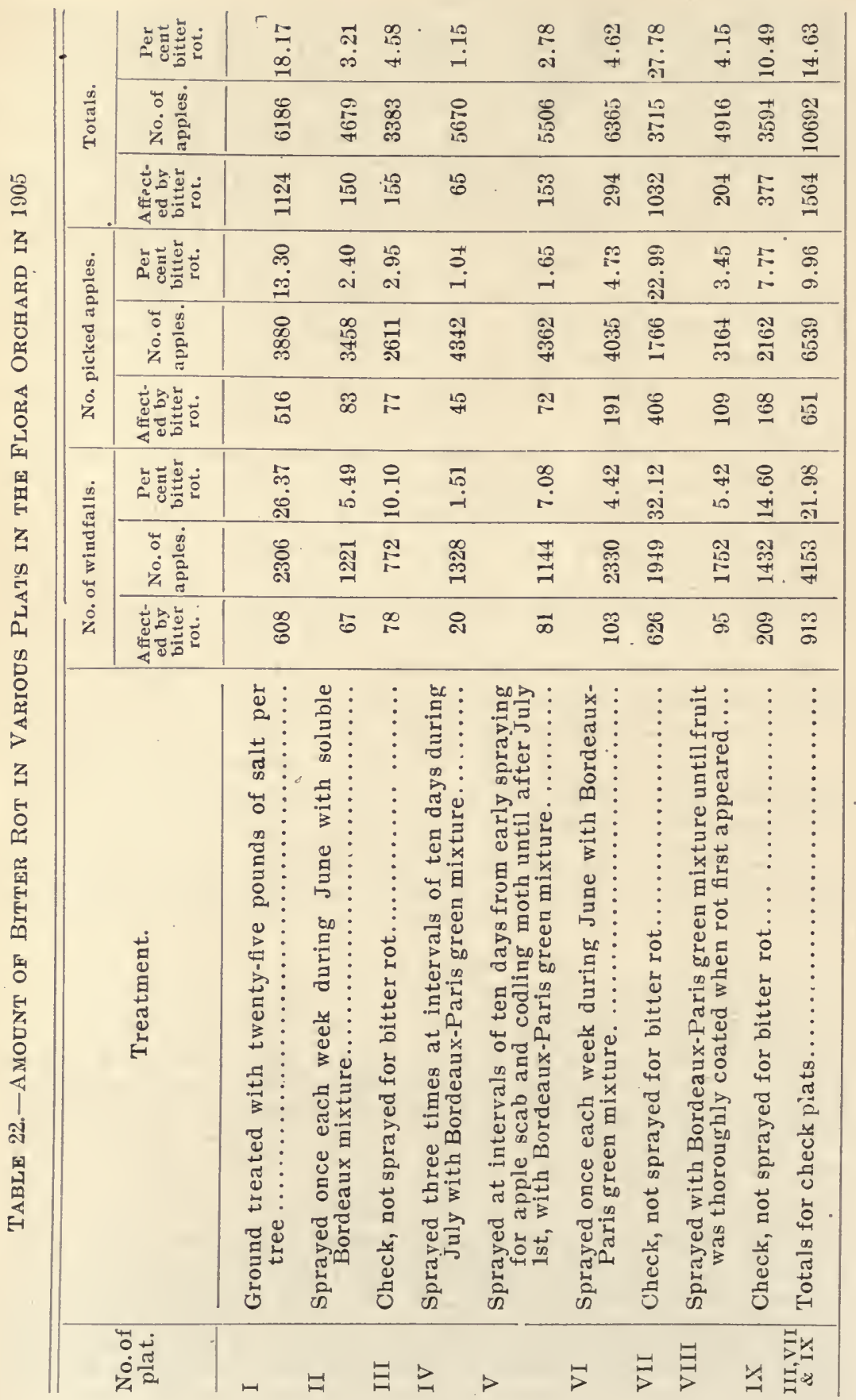


(For plan of plats see p. 5I5):

Bitter rot was first discovered in these plats on July 25 th. The fallen apples were gathered and recorded August 5th, I6th, 2Ist, September 8th, 22d, and October $4^{\text {th }}$ and 5 th. On the latter date the crop remaining upon the trees was harvested, and the data tabulated below give the results of the experiments.

.The results of the experiment in the Flora orchard are strikingly in accord with the results obtained in the Flora, Olney, and Kell orchards in I904. Plat IV which received three sprayings during July, or as near to the time of the first appearance of the bitter rot as they could be applied in accordance with a plan of spraying at intervals of ten days, gave a very perfect degree of control of the disease, and proved somewhat more effective than spraying either during June or after the appearance of the rot. Spraying both in June and after the appearance of the rot, had a decidedly beneficial effect in preventing the disease. The treatment of the ground with salt produced no apparent diminution in the infection. In fact more bitter rot was found in that plat than in the average of the three check plats. The accompanying table shows the relative saving effected by the various treatments over the average of the check plats.

\section{Table 23.-Percentage Saving Shown by the Treated Plats Over THE CheCK Plats}

\begin{tabular}{|c|c|c|}
\hline $\begin{array}{l}\text { No, of } \\
\text { plat. }\end{array}$ & Treatment. & $\begin{array}{l}\text { Percentage } \\
\text { gain over } \\
\text { average } \\
\text { check plat. }\end{array}$ \\
\hline I & $\begin{array}{r}\text { Ground treated with twenty-five pounds of salt per } \\
\text { tree } \ldots \ldots \ldots \ldots \ldots \ldots \ldots \ldots \ldots \ldots \ldots \ldots \ldots \ldots \ldots \ldots \ldots \ldots \ldots \ldots \ldots \ldots \ldots\end{array}$ & None \\
\hline II & 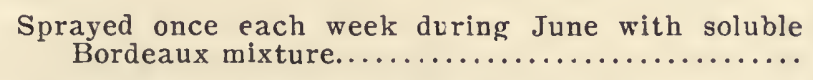 & 78.06 \\
\hline IV & $\begin{array}{l}\text { Sprayed three times at intervals of ten days during } \\
\text { July with Bordeaux-Paris green mixture............ }\end{array}$ & 92.14 \\
\hline $\mathrm{V}$ & $\begin{array}{l}\text { Sprayed at intervals of ten days until July 1st with } \\
\text { Bordeaux.Paris green mixture } \ldots \ldots \ldots \ldots \ldots \ldots \ldots\end{array}$ & 81.00 \\
\hline VI & $\begin{array}{l}\text { Sprayed once each week during June with Bordeaux } \\
\text { Paris green mixture } \ldots \ldots \ldots \ldots \ldots \ldots \ldots \ldots \ldots \ldots\end{array}$ & 68.42 \\
\hline VIII & $\begin{array}{c}\text { Sprayed with Bordeaux-Paris green until fruit was } \\
\text { thoroughly coated when disease first appeared }\end{array}$ & 71.63 \\
\hline
\end{tabular}

The figures given in the above tabulation indicate very clearly the high degree of benefit derived from all the different forms of spraying employed in the experiment and corroborate the results of previous years in which from 70 to 90 percent of all the fruit liable to bitter rot was saved by spraying with Bordeaux mixture. 
Orchard of John Blackligdge, Clay City, Clay County, ig05

A very comprehensive series of eighteen plats was selected in the Ben Davis orchard of Mr. Blackledge, of Clay City, in 1905. There was a promise of a good set of fruit and bitter rot had been prevalent the previous year. Hence it was hoped that some valuable data might be obtained in this orchard. Most of the plats received the first three sprayings for apple scab and codling moth with Bordeaux-Paris green mixture made up according to the standard formula. Plats XIII and XVI, however, were sprayed with the dust Bordeaux-Paris green preparation, Plats VII and XVIII received the first early spray only, while Plats XI and XIV were not sprayed at any time during the season. The early treatments were given April I I th to I4th, April 28th and 29th, and May 5th to 9th. The schedule of treatments planned for each plat was as follows:

Plat I-Salt, one application; twenty-five pounds to each tree evenly spread on the ground.

Plat II-To be sprayed three times at intervals of about ten days beginning about July Ist using Bordeaux-Paris green mixture.

Plat III-Check, to receive no spray after first three applications.

Plat IV - Commencing after third early application to be sprayed at intervals of ten days until after July Ist, using Bordeaux-Paris green mixture.

Plat $V$ - To be sprayed four times in June, on or about the $4 \overline{t h}$, I Ith, I8th, and 25th, using Bordeaux-Paris green mixture.

Plat VI-To be sprayed until the fruit was thoroughly coated as soon as bitter rot first appeared with Bordeaux-Paris green mixture.

Plat VII-Check, to receive no spray whatever after the first three applications.

Plat VIII - To be sprayed until the fruit was completely coated after bitter rot had become thoroughly established, with BordeauxParis green mixture.

Plat $I X$-To be sprayed with copper sulphate solution, three pounds to fifty gallons of water. To be applied ten days after third spraying and then if no foliage injury followed to be repeated every ten days.

Plat $X$-To be sprayed with copper sulphate solution, six pounds to fifty gallons of water. To be applied ten days after third spraying and then if no foliage injury followed to be repeated every ten days.

Plat $X I$-Check, to receive no spray whatever.

Plat XII-Liquid, to be given three applications of BordeauxParis green mixture at intervals of ten days, beginning ten days after third application. 
Plat XIII-Dust, to be applied at the same time the liquid spray was applied to Plat XII.

Plat XIV-Check, to receive no spray whatever.

Plat $X V$-Liquid to be given six applications of BordeauxParis green mixture at intervals of ten days beginning ten days after the third spraying for apple scab and codling moth.

Plat XVI-Dust, to be applied at the same time the liquid spray was applied to Plat XV.

Plat XVII-To be treated with twenty-five pounds of salt to each tree but to receive no early sprayings.

Plat XVIII-Check, to receive no treatment whatever.

Bitter rot was first noticed July 2 Ist and occurred rather spasmodically after every rain and warm spell throughout the season.

The disease varied considerably in the severity with which it attacked various parts of the orchard. There was very little rot on Plats VIII and XVI which were located at the sonth end of the orchard. Plat X which was located in a low place somewhat isolated from the rest also showed almost no infection, and Plat XVII contained only two trees neither of which was much infested. These four plats, then, are left out in the tabulation of data which follows. Windfalls were gathered July 7 th to I 3 th, August $3^{\text {d }}$ to 7 th, I6th to I9th, 24 th and 25 th, September Ist to 4 th, 7 th and 8 th and 20 th to $22 \mathrm{~d}$. The crop was harvested September 25 th to October $3 \mathrm{~d}$, and the records completed as follows, Table 24 .

In this orchard again plats sprayed several times just previous to the discovery of the disease showed very much less bitter rot than the other plats. Spraying until the fruit was thoroughly coated with Bordeaux mixture either as soon as the disease was discovered or after it had become thoroughly established proved much less effective in combating it than did the same treatment in the Flora orchard. Spraying with pure copper sulphate solution gave no decisive results. In fact there was a larger infection of the disease in Plat IX, which was treated with three pounds of copper sulphate to fifty gallons of water, than in some of the check plats. Dust spraying proved very unsatisfactory. The highest infection occurring in any plat was shown by Plat XIII, which was sprayed three times after the early sprayings with dust Bordeaux-Paris green mixture. The three early sprayings with ordinary Bordeaux mixture for scab and codling moth appear to have exercised a very considerable degree of control over bitter rot. In the check plats which received only the three early treatments the average amount of the total crop affected was 10.86 percent, whereas, in the plats which were not sprayed at all during the entire season, the average amount was 35.59 percent, or nearly three and one-half times as much. Plat XVIII which was sprayed only once during the entire season showed a percentage of 22. 7 percent affected by bitter rot, an amount intermediate between 


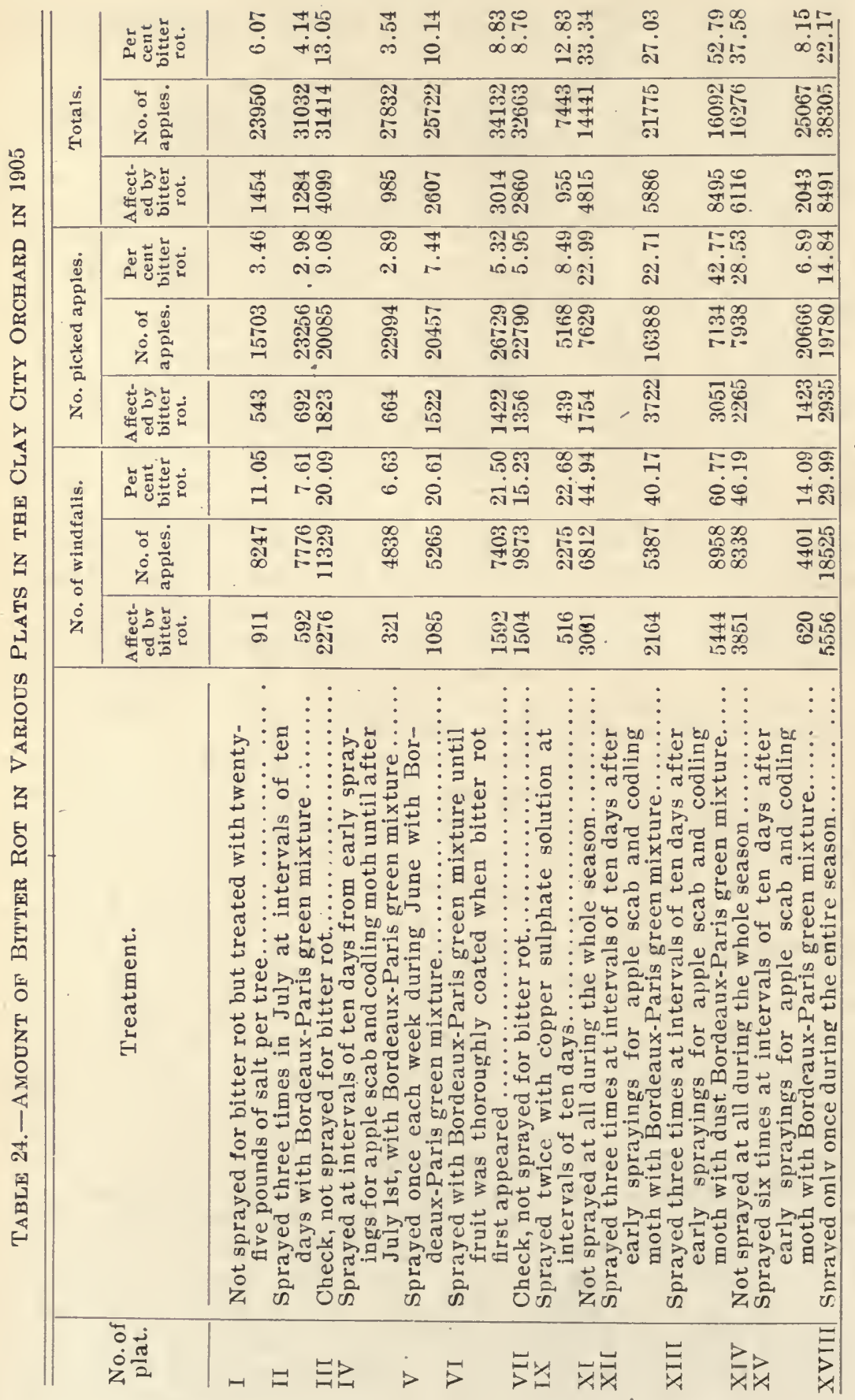




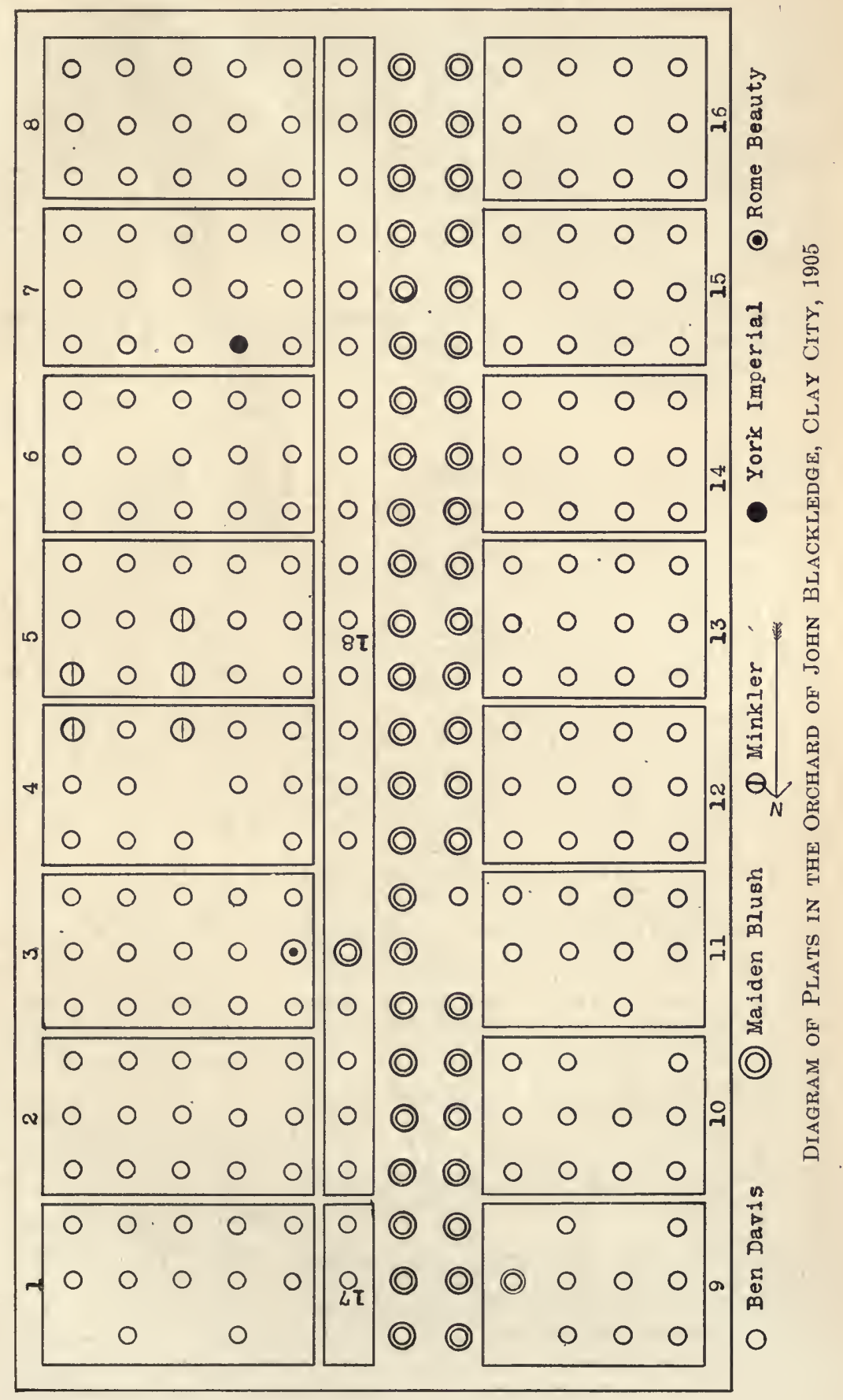


the plats treated three times early and those not treated at all. The following tabulation shows the percentage gain of various plats over the check plats, untreated plats, and dust sprayed plats, etc. The standards taken in the case of the check plats receiving the three early applications of spray for the scab and codling moth are derived from the totals of the two plats, respectively, in each case, viz., the totals of the two Plats III and VII in the first case, and Plats XI and XIV in the second case. Plat XIII is taken as the dustsprayed standard.

Table 25.-Percentage Gains of Various Treated Plats Over UNTREated and DUST Sprayed Plats in the Clay City ORChard IN 1905

\begin{tabular}{|c|c|c|c|c|}
\hline $\begin{array}{l}\text { No. of } \\
\text { plat. }\end{array}$ & Treatment. & $\begin{array}{l}\text { Percent- } \\
\text { age gain } \\
\text { over } \\
\text { early } \\
\text { sprayed } \\
\text { plats. }\end{array}$ & $\begin{array}{l}\text { Percent- } \\
\text { age gain } \\
\text { over un- } \\
\text { treated } \\
\text { plats. }\end{array}$ & $\begin{array}{l}\text { Percent } \\
\text { age gain } \\
\text { over } \\
\text { dust } \\
\text { sprayed } \\
\text { plats. }\end{array}$ \\
\hline I & Not sprayed for rot but treated with salt & 44.11 & 82.94 & 88.50 \\
\hline II & $\begin{array}{l}\text { Sprayed three times at intervals of ten } \\
\text { days in July with Bordeaux-Paris green } \\
\text { mixture. } \quad \ldots \ldots \ldots \ldots \ldots \ldots \ldots \ldots \ldots \ldots\end{array}$ & 61.88 & 88.37 & 92.16 \\
\hline IV & $\begin{array}{l}\text { Sprayed at intervals of ten days until } \\
\text { after July } 1 \text { with Bordeaux-Paris green } \\
\text { mixture } \ldots \ldots \ldots \ldots \ldots \ldots \ldots \ldots \ldots \ldots \ldots\end{array}$ & 67.40 & 90.05 & 93.29 \\
\hline $\mathrm{V}$ & $\begin{array}{l}\text { Sprayed once each week during June } \\
\text { with Bordeaux-Paris green mixture... }\end{array}$ & 6.63 & $7] .51$ & 80.79 \\
\hline VI & $\begin{array}{l}\text { Sprayed until fruit was thoroughly } \\
\text { coated when bitter rot first appeared }\end{array}$ & 18.69 & 75.19 & 83.27 \\
\hline IX & $\begin{array}{l}\text { Sprayed twice with weak copper sul- } \\
\text { phate solution at intervals of ten days }\end{array}$ & $\cdots \cdots$ & 63.95 & 75.70 \\
\hline XII & 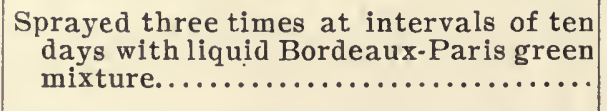 & $\cdots \cdots$ & 24.05 & 48.80 \\
\hline XIII & $\begin{array}{l}\text { Sprayed six times at intervals of ten } \\
\text { days with dust Bordeaux-Paris green } \\
\text { mixture } \ldots \ldots \ldots \ldots \ldots \ldots \ldots \ldots \ldots \ldots \ldots \ldots \ldots \ldots \ldots \ldots\end{array}$ & $\cdots \cdots$ & $\cdots \cdots$ & $\cdots \cdots$ \\
\hline XV & 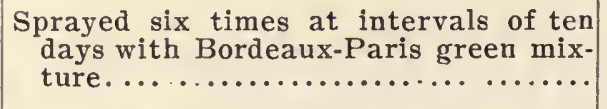 & 24.95 & 77.10 & 84.56 \\
\hline XVIII & Sprayed only once during entire season & ...... & 37.71 & 58.00 \\
\hline $\begin{array}{l}\text { III \& } \\
\text { VII }\end{array}$ & $\begin{array}{l}\text { Sprayed three times early in season for } \\
\text { scab and codling moth } \ldots . . . \ldots \ldots \ldots \ldots\end{array}$ & & 69.49 & \\
\hline
\end{tabular}


A remarkable feature of the results obtained in the Blackledge orchard is the demonstration of the effect of the three early sprayings applied for apple scab and codling moth, in controlling bitter rot. In every instance, as will be seen by comparing columns one and two in the above table, the percentage gain of treated plats over absolutely untreated plats was from 23 percent to as much as 60 percent greater than the gain of treated plats over check plats sprayed three times for apple scab and codling moth. Comparing Plats III and VII, which are given the three early treatments for apple scab and codling moth, with Plats XI and XIV which were not sprayed during the entire season, the two early treated plats show a gain over the two untreated plats of 69.49 percent.

\section{CONCLUSIONS FOR 1905}

Besides confirming various conclusions already drawn that bitter rot may be almost completely controlled by three to four applications of Bordeaux mixture applied at intervals of ten days just previous to the appearance of bitter rot, and that sprayings after the appearance of the rot are of some benefit, the data obtained in I905 pointed to the following conclusions:

I. That the spring sprayings for apple scab and codling moth are, in seasons like that of 1905 , effective in controlling a very considerable percentage of bitter rot.

2. That dust spray is ineffective in combating the disease.

3. That spraying with pure copper sulphate solution is not an effective way of controlling bitter rot.

\section{IN GENERAL}

\section{Weather Conditions Favorable For BitTér Rot}

The spasmodic and erratic occurrence of the disease in different seasons has long been noted and has been more or less generally taken as indicating a relationship between the weather conditions and the development of the fungus. The year 1900 proved to be a year of exceptional severity in the attacks of the disease and it was, in part, the uncommon destructiveness of the pest during that year that led the Horticultural Department of the University of Illinois to inaugurate this line of work looking towards the discovery of a means to control the bitter rot fungus. Yet in the following year, I90I, the experimental work. of the Department was rendered null by the failure of bitter rot to develop in orchards where the disease had been prevalent the year before. In reference to the season of I90 I, Mr. A. V. Stubenrauch, who had charge of the field investigations that year, says: "The exceedingly dry hot summer seems to have been very unfavorable for the development and spread of bitter rot. Iast year, I900, the disease destroyed practically the 
entire crop wherever it made its appearance. The disease has not been nearly so bad this year. Many orchards badly affected last year were entirely free this season; many were only slightly affected and no case of a total failure has come to my notice."* The year I902 proved favorable again for the rot and in all the orchards under experimentation check plats showed an infection of 44 percent to 89 percent of the total crop. In 1903 the bitter rot was present in five orchards under test but in only one of them was there an infection of commercial importance, the infection in the exceptional case being, however, very serious, and amounting to 63 percent of the crop. In 1904 the disease was present again and was apparently more general in its spread. It was more destructive than in I9O3 but less so than in I902, in the orchards which. were under observation. In 1905 only two orchards were under experimentation, but in both of these the disease was sufficiently serious to destroy from I 4 to 35 percent of the crop in the untreated plats. Comparing different seasons in the same orchard it will be seen by reference to the following table in the Tamaroa orchard, where three seasons' work were carried on, there was an infection of 68.54 percent in 1902 , I.27 percent in 1903, and I5.94 percent in 1904 . In the Flora orchard there was an infection in 1902 of 83.32 percent, in 1904 of II.68 percent, and in 1905 of 14.63 percent. A glance at the table of infections which follows will serve to impress still further the erratic manner in which the disease appears from season to season :

Table 26.-Percentage of Bitter Rot in Untreated Plats During DIFFERENT SEASONS FROM 1902 to 1905

\begin{tabular}{|c|c|c|c|c|c|}
\hline Year & Orchard. & $\begin{array}{l}\text { Per } \\
\text { cent } \\
\text { bitter } \\
\text { rot. }\end{array}$ & Year & Orchard. & $\begin{array}{l}\text { Per } \\
\text { cent } \\
\text { bitter } \\
\text { rot. }\end{array}$ \\
\hline 1902 & 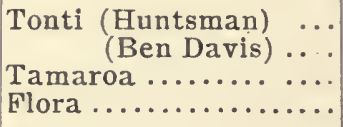 & $\begin{array}{l}89.27 \\
44.95 \\
68.54 \\
83.32\end{array}$ & 1904 & 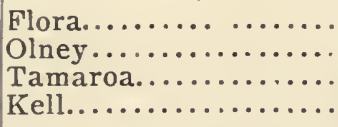 & $\begin{array}{r}11.68 \\
1.18 \\
15.94 \\
21.50\end{array}$ \\
\hline 1903 & 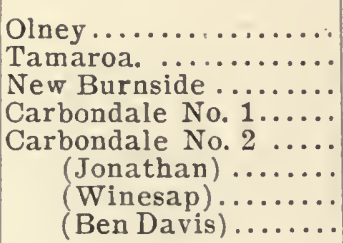 & $\begin{array}{r}.32 \\
1.27 \\
3.51 \\
7.05 \\
62.97 \\
23.69 \\
63.09\end{array}$ & 1905 & $\begin{array}{l}\text { Flora } \ldots \ldots \ldots \ldots \ldots \ldots \\
\text { Clay City } \ldots \ldots \ldots \ldots\end{array}$ & $\begin{array}{l}14.63 \\
35.59\end{array}$ \\
\hline
\end{tabular}

*Circular No 43, University of Illinois Experiment Station, 1902-p. 4. 
This irregularity in the behavior of bitter rot is not confined alone to different seasons. It makes its appearance in different years at very different dates and in different orchards it may occur at more or less widely separated intervals in the same season. Bitter rot is a disease which ordinarily develops comparatively late in the season causing the greatest amount of damage when the fruit is fairly well matured and not far from the picking stage in its degree of ripeness, but we now know that the destruction is sometimes greatest in July when the late varieties are not half grown. Infected apples in orchards subject to the disease are found at various dates during the months of June and July. In I902 the first record of its existence on young apples was made June 28 th but the specimens showed that the infection must have been at least two weeks earlier, and it has been otherwise sufficiently proved that in numerous instances the attack occurs as soon as the middle of June. Some interesting data in this regard appears in the tabulation following:

Table 27.-Date of First Appearance of Bitter Rot During DifFERENT SEASONS

\begin{tabular}{|c|c|c|c|c|c|}
\hline Year. & Owner of orchard. & Location. & County. & Variety. & $\begin{array}{l}\text { Date of first } \\
\text { appearance } \\
\text { of bitter rot. }\end{array}$ \\
\hline \multirow[t]{2}{*}{1902} & $\begin{array}{l}\text { J. B. Brokaw .... } \\
\text { F. L. Willia ms .. }\end{array}$ & Tonti & Marion & Huntsman & July 8 th \\
\hline & Däle Mann ...... & $\begin{array}{l}\text { Tamaroa } \\
\text { Flora }\end{array}$ & $\begin{array}{l}\text { Perry } \\
\text { Clay }\end{array}$ & $\begin{array}{l}\text { Ben Davis } \\
\text { WillowTwig }\end{array}$ & $\begin{array}{l}\text { July } 5 \text { th } \\
\text { July } 10 \text { th }\end{array}$ \\
\hline \multirow[t]{4}{*}{1903} & $\begin{array}{l}\text { J. L. Zook ...... } \\
\text { E. L. Williams .. }\end{array}$ & Olney & Richland & Ben Davis & Aug. 7th \\
\hline & J. W. Heaton Son & $\begin{array}{l}\text { Tamaroa } \\
\text { NewBurnside }\end{array}$ & $\begin{array}{l}\text { Perry } \\
\text { Johnson }\end{array}$ & $\begin{array}{l}\text { Ben Davis } \\
\text { Early Harvest } \\
\text { Ben Davis }\end{array}$ & $\begin{array}{l}\text { July } 6 \text { th } \\
\text { June } 25 \text { th } \\
\text { Sept. } 7 \text { th }\end{array}$ \\
\hline & H. E. Allen. & Carbondale & Jackson & $\left.\begin{array}{l}\text { Jonathan } \\
\text { Winesap } \\
\text { Ben Davis }\end{array}\right\}$ & Aug. 5th \\
\hline & Charles Allen... & Carbondale & Jackson & Ben Davis & $\begin{array}{l}\text { Before } \\
\text { Aug. 17th }\end{array}$ \\
\hline \multirow[t]{2}{*}{1904} & $\begin{array}{l}\text { Dale Mann...... } \\
\text { J. L. Zook ...... } \\
\text { F. L. Williams }\end{array}$ & $\begin{array}{l}\text { Flora } \\
\text { Olney }\end{array}$ & $\begin{array}{l}\text { Clay } \\
\text { Richland }\end{array}$ & $\begin{array}{l}\text { Willow Twig } \\
\text { Ben Davis }\end{array}$ & $\begin{array}{l}\text { July } 24 \text { th } \\
\text { July } 27 \text { th }\end{array}$ \\
\hline & $\begin{array}{l}\text { and Son......... } \\
\text { W. T. Storment. }\end{array}$ & $\begin{array}{l}\text { Tamaroa } \\
\text { Kell }\end{array}$ & $\begin{array}{l}\text { Perry } \\
\text { Marion }\end{array}$ & $\begin{array}{l}\text { Ben Davis } \\
\text { Ben Davis }\end{array}$ & $\begin{array}{l}\text { July } 16 \text { th } \\
\text { July } 22 d\end{array}$ \\
\hline 1905 & $\begin{array}{l}\text { Dale Mann ...... } \\
\text { John Blackledge }\end{array}$ & $\begin{array}{l}\text { Flora } \\
\text { Clay ,City }\end{array}$ & $\begin{array}{l}\text { Clay } \\
\text { Clay }\end{array}$ & $\begin{array}{l}\text { Willow Twig } \\
\text { Ben Davis }\end{array}$ & $\begin{array}{l}\text { July } 24 \text { th } \\
\text { July } 21 \text { st }\end{array}$ \\
\hline
\end{tabular}

This characteristic irregularity in the behavior of the disease must possess some significance in the history of its development, and this significance must be concerned either with the conditions controlling the original infection or the conditions controlling the virulence of the disease after infection takes place. In all of the orchards under experimentation enough bitter rot appeared every season to infect the entire crop, under conditions favorable to the growth and 
spread of the fungus, Table 26: The characteristic irregularity of bitter rot must therefore be due to the presence or absence of those conditions which are favorable to its distribution and growth. What then are the circumstances which favor the development of the disease?

In Bulletin No. 77 of this Station it was stated that the rapidity of development depends upon climatic conditions. It is essentially a hot weather disease and moisture is necessary for the distribution and germination of the spores. It is true that the infection of the fruit sometimes becomes apparent and the progress of the disease is abundantly evident when the atmosphere is very dry; but this only happens after the fungus has gained entrance to the apples, which must have occurred during a previous period of rainy weather or heavy dews. Moisture, generally in the form of rain, and high temperature are necessary to start an epidemic. These of course are only favorable conditions for the development of the fungus which is, itself, the direct agent of destruction. Fortunately the fungus is not very resistant to unfavorable conditions and may sometimes die out entirely during one year where it has been previously abundant. This, with its power of enormous multiplication under circumstances well suited to its growth, sufficiently accounts for the marked irregularity in the time and virulence of its attack.

Scott says, "The predominating conditions that influence the development of bitter rot are temperature and humidity. A few days of hot showery weather may start an epidemic that will destroy the entire crop of certain varieties, provided the fungus is present.

"Cold is decidedly unfavorable to the fungus and it rarely does any damage during a cool season. An outbreak may be almost completely checked by a few days of cool weather, especially when the mean temperature remains below 70 degrees $\mathrm{F}$."*

Von Schrenk and Spaulding write in regard to this point that "The factors which determine the time of the appearance of the disease are probably (I) the age of the fruits;.(2) the temperature and humidity of the air; (3) the presence of spore distributing centres.

"Warm, sultry weather, particularly after a rain, forms the ideal condition for the development of bitter rot. In cool dry summers the bitter rot is usually present but sparingly. A short series of hot, wet days in August may bring about a sudden and very destructive attack. Nights with a heavy fall of dew alternating with hot days are usually followed by an extensive development of the disease."**

*The control of Apple Bitter Rot, W. M. Scott. U. S. Department of Agriculture, Bureau of Plant Industry-Bulletin No.93. pp. 12-14.

**'The Bitter Rot of Apples, Von Schrenk and Spaulding, U. S. Department of Agriculture, Bureau of Plant Industry-Bulletin No. 44. p. 15. 
If the prevalence of the disease in different seasons be referred to the weather conditions for the corresponding seasons there should be no difficulty in settling the relation between the virulence of the disease and the climatic conditions obtaining during the season. The accompanying tabulation of temperatures and rainfall for various points in southern Illinois is compiled from records in the Agronomy Department at the University of Illinois. In some cases the readings appear high owing to the class of thermometers used by some observers, but as the readings are merely for relative references in this connection, they are sufficiently accurate to serve the purpose of comparisons, pp. 538-540.

It will be noted that in the year 1900 when the bitter rot was so enormously destructive in the southern part of the state the month of June was exceptionally wet, nearly twice the average rainfall for that month being noted at Flora, Mount Vernon, and Centralia, and two inches more than the average at Olney. The mean temperature for the year proved to be one to three degrees lower than the average but still from 2.4 to 4.2 degrees warmer than that mentioned by Scott as being favorable to the growth of the fungus, i. e. 70 degrees $\mathrm{F}$. July also proved unusually wet, considerably more than the average amount of rain falling at all points except Centralia, and the weather, while not exceptionally warm for the district, ranged from 5.5 to 8.2 degrees above 70 degrees F. August proved to be dry, the precipitation falling considerably below the average, but the damage had already been done and the infection was complete during the preceding months. The year I9or, which has already been referred to as a season in which little bitter rot occurred, offers an interesting contrast in respect to moisture conditions to the preceding year. In every instance during the months of June and July the rainfall is markedly below the yearly average, and even the precipitation during the month of August, which proved to be a little more than the average for that month, is not excessive, the largest fall recorded being 3.52 inches for the month. The prevailing temperatures throughout were higher than their respective averages. The conditions and results of these two seasons bear out very clearly the contention that warm moist conditions are favorable to the spread of the disease and tend to discredit the theory advanced some years ago in certain quarters that it is a hot dry-weather fungus.*

The season of 1902 as shown by the results of the work in the experimental plats, Table 26 , proved favorable again to the disease, though reports from commercial quarters did not indicate so

* Note reference to this theory by Burrill, Transactions Illinois Horticultural Society, 1901, p. 186. 


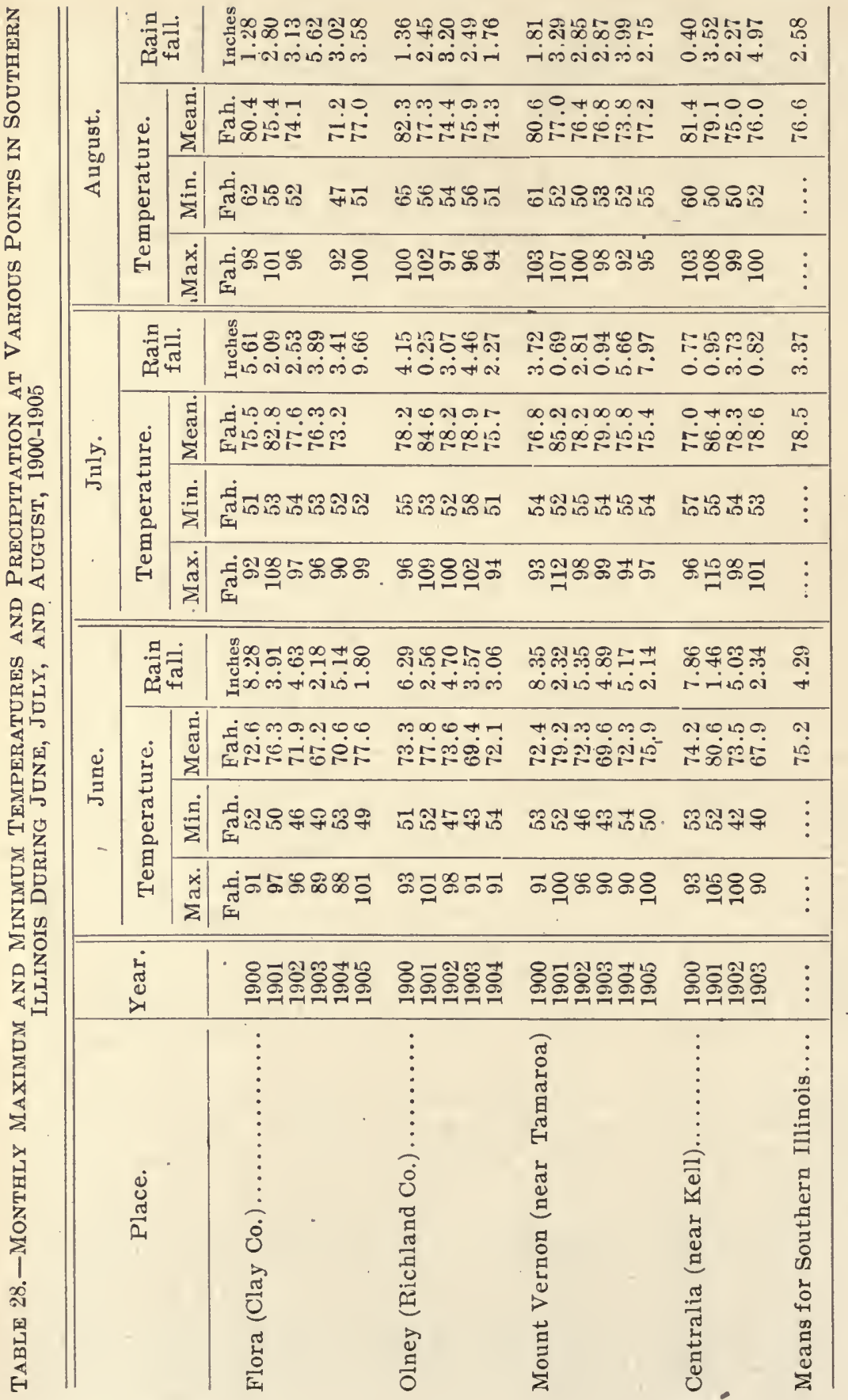




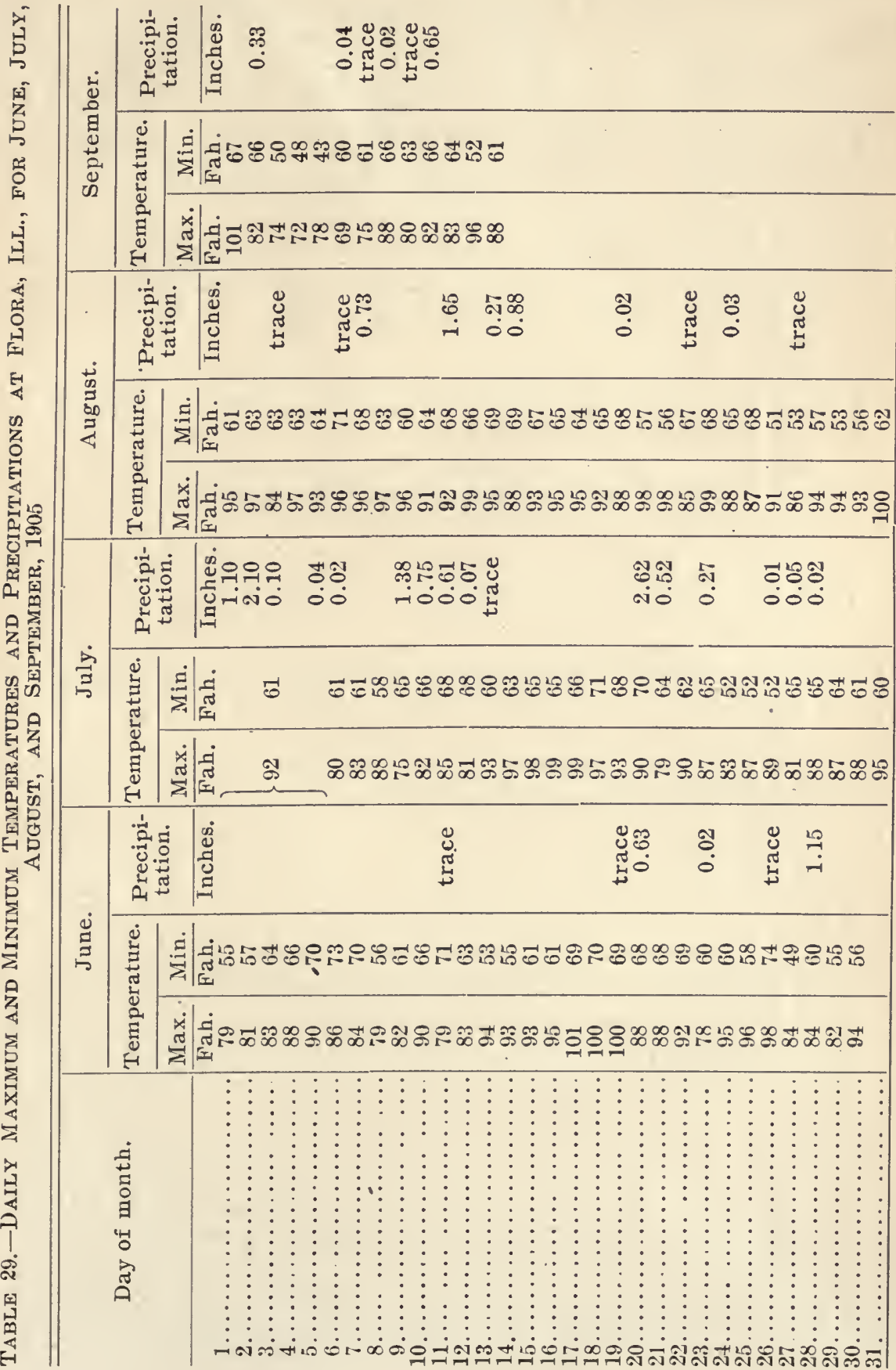




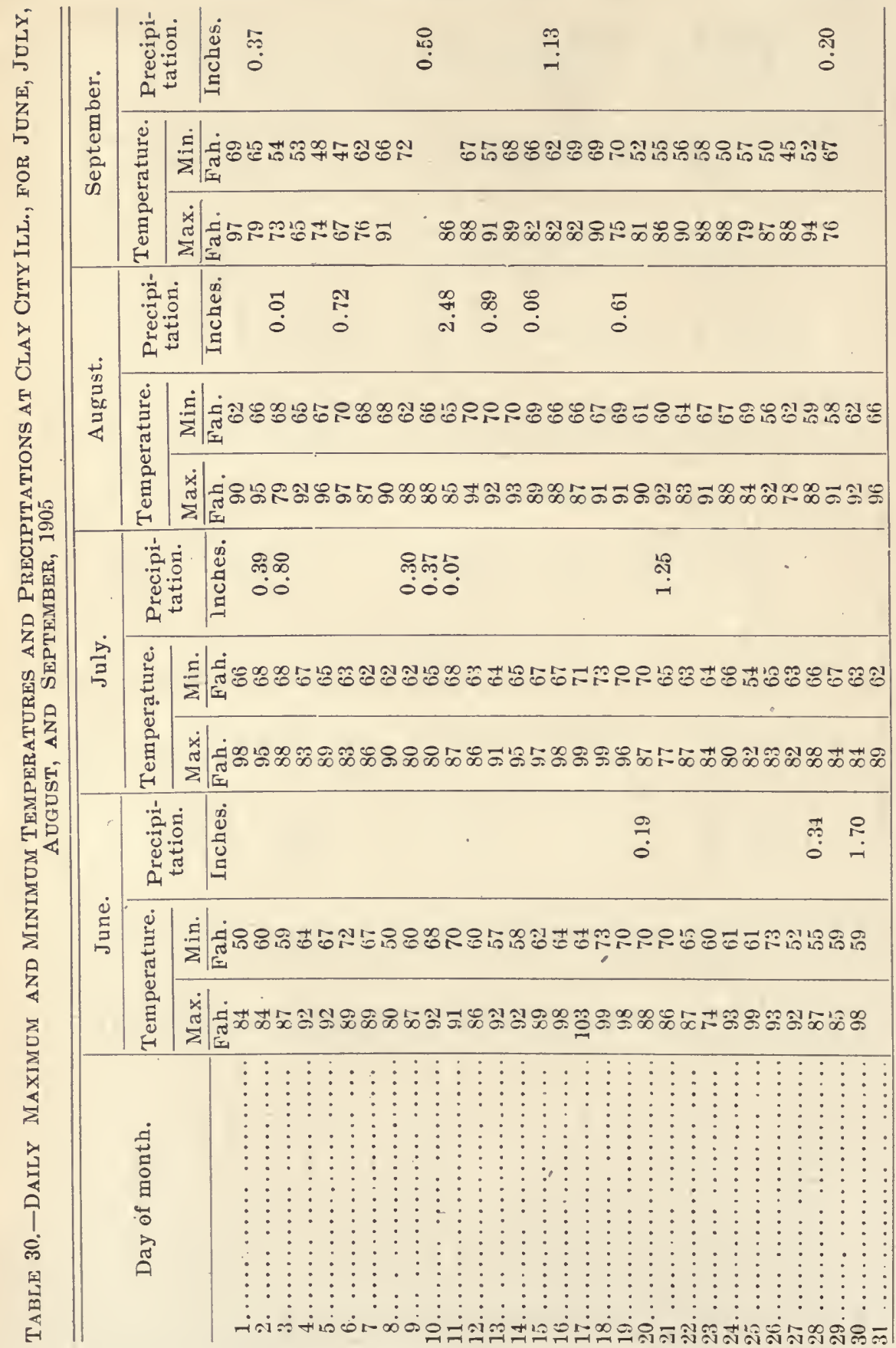


severe an attack as in Igoo. Glancing at the weather conditions for I 902 we find a period of high temperatures and more than the average amount of rainfall for the month of June, average temperatures and a moderate rainfall for July, and moderate temperatures and more than an average rainfall during August. The extremes of the two preceding seasons were absent and the bitter rot showed itself with less destructiveness than in Igoo but with more than in I90I. The succeeding seasons afford data very similar to those already noted, but some further facts of interest in this regard are furnished by the data for 1903, 1904, and 1905. In 1903 the precipitation proved about normal for June and July but above the average in most cases for August, with the result that the bitter rot appeared late in the season, the first infection occurring, with one or two exceptions in August, Table 27. During the following two years the heavy rainfall occurred during July, and without exception the infection of bitter rot occurred during that month.

It may be safely concluded that moist weather with a considerable precipitation and a high temperature are favorable to the spread and growth of bitter rot. There was no opportunity to note the effect of moist cold weather though it might be argued from analogy, there being no evidence of the disease in Northern and very little in Central Illinois, where the rainfall is abundant and the mean temperature lower, that moisture without high temperature is not favorable to the development of the disease. Hot weather alone unaccompanied by moisture proved unfavorable to the spread of the disease, as seen in the season of Igor, but hot weather alone did not prevent the disease from accomplishing its work of destruction after infection had once occurred, as, was observed in Igoo when the dry month of August followed the abnormally wet months of June and July.

\section{EFFECT OF SPRAYING ON BITTER ROT}

That spraying will control ninety percent or more of the damage liable to occur from bitter rot when the proper materials are applied at the proper time and in the proper way has been conclusively demonstrated in a considerable number of instances. In 1902 as much as 9 r.26 percent of the fruit liable to attack by bitter rot was saved in an orchard at Tonti, where there was an infection of the disease in the check plat amounting to 44.95 percent, Table 2. In I903 trees sprayed only twice for the disease showed an average saving of 59.85 percent, where 62.97 percent of the entire crop was infected, Tables I3 and I4. In I904 as much as 98.20 percent was saved in an orchard at Kell, where 20 to 23 percent of the fruit on the check plats showed infection, Tables I8 and I9. In I905, 92.I4 percent of the fruit liable to the disease was saved in an 
orchard at Flora, where one check plat showed I0.49 percent of infected fruit and a second, 27.78 percent, and three check plats showed an average of 14.63 percent, Tables 24 and 25 .

While the remarkably favorable results above mentioned were obtained only under certain specific treatments and not in every experiment, they were obtained in nearly every orchard which showed a uniform and considerable infection of the disease, and in every year of the series except I9OI when the rot failed to appear in the plats selected for experimentation. Moreover, leaving out of consideration these more successful treatments, it appeared that spraying, in almost every instance, whether applied late or early, seldom or frequently, showed some degree of effectiveness in controlling the disease, its effectiveness ranging from ten to ninety percent according to circumstances.

\section{TIME OF SPRAYING FOR BIT'TER Ro'T}

I. Early or spring sprayings for apple scab and codling moth: The experiments performed in the John Blackledge orchard at Clay City, in 1905 , indicated a possible saving in plats sprayed three times early in the season for apple scab and codling moth, of 69.49 percent, over plats which received no early treatment. In many instances, however, in other orchards, the total saving effected by the three early sprayings, together with various subsequent ones, amounts to less than a total of 69.49 percent. Therefore, we must conclude that the circumstances in the orchard at Flora, in 1905, were somewhat exceptional, and that so complete a saving is not to be depended upon by the orchardist. There is no doubt, however, that, in seasons like that of 1905 , some degree of protection is afforded by these early sprayings.

2. Spraying after the early treatments for apple scab and codling moth and before the appearance of the disease: In every instance where this treatment was given the amount of bitter rot was either comparatively or actually small. The more complete the general infection, the more clearly defined was the effect of spraying at this time in reducing the amount of bitter rot. There were, of course, a number of variations of this treatment, due to the very considerable period of time which usually elapsed between the date of the last spraying for apple scab and codling moth and the date of the first infection of bitter rot; as, for example, three sprayings at intervals of ten days after the third early treatment for apple scab and codling moth; four sprayings at intervals of one iveek during June; three sprayings at intervals of ten days commencing about July Ist, and others. Of these treatments the most effective were those which were applied most shortly before the appearance of the rot. In 1902 
the most successful treatment was one in which a plat was treated five times before the appearance of bitter rot, the last spraying being made July 2d, six days before bitter rot appeared. This plat was also sprayed once after the discovery of the disease, but, as other plats sprayed after the appearance of the fungus showed comparatively little benefit from the treatment, it may be concluded that the high degree of protection evidenced by this plat is not to be attributed to the last spraying, Table 2. In the orchard of H. E. A1len at Carbondale, where the best results were obtained in 1903 , the highest degree of protection was afforded by plats sprayed twice before the appearance of the disease. The treatments, which were given June 26 th and July Ist, were apparently too early to give the best results, for bitter rot did not appear until August 5th, and instead of saving over 90 percent of the fruit liable to infection, there was a saving of only 49.39 percent in the case of Ben Davis, 69.44 percent in the Winesap, and 60.7I percent in the case of Jonathan, Table I4. In I904 the most conclusive results were obtained in the orchard at Kell. Here three different treatments were given during the two months preceding the first appearance of bitter rot and all were remarkably successful in controlling the disease. The last spraying in each, however, was given but a short time before the date when the first infection was discovered, July 22d. Plat IV was sprayed twice before the appearance of the disease and once after, July 9th, I9th and 29th and it afforded a slightly less perfect protection than the treatments given Plats V and VI, in which all the sprayings were given previous to the first discovery of the fungus. Plat V, which was sprayed May 3oth, June 8th, 20th, 29th, and July 9th, evidenced the most complete control of the three, protecting 98.20 percent of the fruit liable to attack by the disease. Plat VI, sprayed-at weekly intervals throughout June, protected 95.42 percent of the fruit liable to infection and stood second in effectiveness. It must be noted, however, that this plat received four sprayings and Plat V, five sprayings, as compared with only three sprayings for Plat IV, one of which was after the appearance of the rot; and yet the control in Plat IV amounted to 94.59 percent, showing an efficiency almost equal to that of the more elaborately, but earlier treated plats. 'It seems very likely indeed that, had the third treatment been given just before the infection occurred, the protection would have been as great in this plat as in the others. At any rate it indicates that the most effective sprayings are those which are applied most shortly before the first bitter rot infection occurs, Tables 18 and I9. In 1905 in both the Flora and the Clay City orchards the greatest protection was afforded by three applications of Bordeaux at intervals of ten days during July. Bitter rot appeared in the former orchard on July $25^{\text {th }}$ and the thircl 
spraying occurred on that date, thus bringing these sprayings immediately up to the time of the first infection. The disease appeared in the orchard at Clay City on July 2Ist, so that the third spraying was given shortly after the first infection, Tables 22 to 25 .

3. Spraying so as to coat the fruit thoroughly as soon as bitter rot appears: Although not so successful a treatment as spraying at intervals of a week to ten days just previous to the first infection, spraying so as to coat the apples thoroughly as soon as the disease appeared had a marked effect in reducing the loss from bitter rot. This treatment was first given in 1904, and in the Kell orchard, where it proved most successful that year, it effected a saving of 72.02 percent over the check plats as compared with a saving of 94.59 percent effected in a plat sprayed twice previous to the first infection and once immediately after the infection, Table I9. In the Flora orchard in 1905 this treatment resulted in a saving of 71.63 percent as compared with a saving of 92.14 percent in the most successful plat, Table 23. During the same season another plat similarly treated in the orchard at Clay City showed a saving of 75.I9 percent compared with a saving of 90.05 percent in the most successful plat, Table 25. It would appear, therefore, that this treatment is to be strongly recommended to those fruit. growers who find their orchards unexpectedly attacked by the disease and who have neglected to give the earlier sprayings as a matter of precaution. In this connection special attention must be called to the fact that this treatment was always given as soon as the first infected apple was found and not when the diseased apples had become numerous and rot thoroughly established. Moreover to coat the fruit thoroughly with spray it is necessary to make three applications, the second application being made after the first has dried and the third after the second has dried.

4. Spraying after bitter rot has become thoroughly established: Tests of this treatment proved uncertain and gave varying results. In some instances a considerable degree of protection was afforded and in others very little or no benefit resulted. This fact taken in connection with the habit of the fungus itself of growing among the tissues of the fruit beneath the skin would appear to indicate that spraying after the fungus has gained an entrance into the fruit is useless as a means of controlling the disease, but that this late spraying may in some cases be the means of preventing the spread of the disease from affected to unaffected apples. In I902 a number of plats were treated after the disease was fully established. A plat in the Tamaroa orchard sprayed five times after the disease was fully established gave a saving of 29.59 percent over a check plat; a plat sprayed three times showed a saving of 12.52 percent, Table 5 ; two plats in the Flora orchard sprayed five times after the ap- 
pearance of the disease showed a saving of 28.12 percent as a result of this treatment, Table 7. In 1903, in the only orchard which afforded definite data, that of Mr. H. E. Allen at Carbondale, the plats sprayed after the appearance of the disease gave, with the exception of the Winesap plat, a higher percentage of bitter rot than the check plats. 'The Winesap plat showed some gain over the check plat but the entire infection was less among the fruits of that variety than among the fruits of the other two varieties, Jonathan and Ben Davis, Table I3. In 1904 in the Kell orchard the late treatment proved quite successful, resulting in a gain over the check plats of 8I.9I percent. The best plat of the series, however, gave a saving of 98.20 percent of all the fruit liable to infection, or I6.29 percent more than the late sprayed plat, Table I9. These results indicate, therefore, the unreliability of this treatment and suggest that it should be applied only as a desperate expedient in cases where carelessness or force of circumstances have prevented earlier treatments and not as a certain or infallible remedy.

5. Spraying dormant wood: Since the bitter rot fungus passes the winter in cankers on the branches of the trees and also in the mummies which sometimes remain on the trees, it was thought that treatment of the dormant wood might destroy the fungus in this stage and prevent fresh infection the next year. In I903 plats were sprayed in the orchards at Olney and at Tamaroa with a copper sulphate solution, one in each orchard in the fall and one in the spring, while the trees were dormant. There was as much rot in these plats as in the check plats, but as very little rot developed in any of the plats the results were inconclusive, Tables 9 and IO. In I904 two plats in the Kell orchard, one treated with Oregon Wash, and one treated with copper sulphate solution, showed even more rot than the check plats, 25. I 7 percent and $28.8 \mathrm{I}$ percent, respectively, of the entire crop, being affected Table I8. The average results for all the orchards treated in 1904 show that there was a slightly greater loss of fruif from bitter rot in the plats which were treated on the dormant wood than in the check plats, amounting in case of Oregon Wash to I0.93 percent of the entire crop, and in case of copper sulphate solution to I2.44 percent, as compared with 10.52 percent for the check plats, Table 20. These results are considered sufficiently decisive to warrant the conclusion that spraying the dormant wood is entirely ineffective in controlling bitter rot.

\section{MATERIALS FOR SPRAYing}

I. Liquid Bordeaux mixture: Liquid Bordeaux mixture marle up in the proportions of four pounds of copper sulphate, four pounds of lime, and fifty gallons of water was the fungicide used in the 
great majority of the tests. To this mixture were commonly added four ounces of Paris green as an insecticide, but this material was not expected to act in connection with the copper sulphate as a preventive of bitter rot. It is sufficient to say that all the most successful treatments were obtained by the use of this fungicide.

2. Soluble Bordeaux mixture: Soluble Bordeaux mixture was used in but one instance, being applied to Plat II in the Mann orchard at Flora in 1905 . It resulted in a saving of 78.06 percent as compared with a saving of 68.42 percent in one plat similarly treated with regular Bordeaux and of $8 \mathrm{I} .00$ percent in a second plat treated with the regular Bordeaux mixture. Its efficiency in this test appeared to be equal to Bordeaux mixture prepared in the usual manner, Table 23.

3. Dust Bordeaux mixture: Dust Bordeaux mixture proved a failure as a means of controlling bitter rot. It was tried in the orchard at Clay City in 1905. Plat XIII in that orchard was sprayed three times at intervals of ten days beginning ten. days after the third treatment for apple scab and codling moth, and compared with an adjoining plat similarly treated with liquid Bordeanx mixture. The dust sprayed plat showed an infection of 52.79 percent of the entire crop as compared with 27.03 percent for the liquid sprayed plat beside it. In fact the dust sprayed plat which received with the three early sprayings for apple scab and codling moth, a total of six applications during the season, showed a higher infection of bitter rot than any other plat in the orchard including the untreated plats which had been left as checks, Table 24 .

4. Pure Copper Sulphate Solution: Pure copper sulphate solution was tried in varying strengths during two seasons. In 1904 two plats in the Kell orchard were sprayed with copper sulphate solution. In the first, where eight ounces of copper sulphate were used to fifty gallons of water, there was an infection amounting to 26.95 percent of the entire crop, or about 5 percent more than appeared in the untreated or check plats. In the second plat, where ten ounces of copper sulphate were used to fifty gallons of water, there was an infection of 18.48 percent of the crop, or a gain over the check plats of about 3 percent. It will be remembered, in comparison with these results, that in this orcliard three different treatments with Bordeaux mixture gave almost perfect control over the rot, Table 18 . In the following year, I905, Plat IX in the orchard at Clay City was sprayed with a solution of copper sulphate consisting of three pounds of the salt to fifty gallons of water. I 2.83 percent of the fruit in the plat was lost by bitter rot as compared with about 10.00 percent in the two check plats, Table 24 . The evidence is then overwhelmingly against the use of pure copper sulphate solution as a fungicide, and when to its ineffectiveness in controlling the bitter rot is added the fact that it caused great dam- 
age to the foliage of a number of the trees treated, it is apparent that this treatment is not only useless as a remedy for bitter rot but is also a menace to the trees. Its ineffectivenss when applied to the dormant wood has already been referred to under another heading.

5. Oregon Wash: Oregon Wash was applied only to the dormant wood. The percentage of bitter rot was a trifle less in plats sprayed with this preparation than in plats sprayed with the copper sulphate solution but the difference was insignificant, not being greater than might be accounted for by differences in the original amounts of infection in the plats themselves, and both proved about equally ineffective in controlling the disease, Table 20.

\section{Applicatrons of Salt to the Ground}

The statement having appeared in some quarters that applications of salt to the soil under the trees had helped to control bitter rot, the treatment was given in comparison with other treatments in the season of 1905 . One plat in the Flora orchard and one plat in the Clay City orchard were treated with twenty-five pounds of salt per tree. In the Flora orchard the plat thus treated showed an infection amounting to I8.I7 percent of the crop, or somewhat higher than the average of the check plats, Table 22. In the Clay City orchard the plat treated with salt was infected to the extent of 6.07 percent of the entire crop, or about 4 percent less than the average of the check plats, Table 24. Since the results vary somewhat from each other but do not in either case deviate very widely from the check plats, it would appear that the difference is due rather to fluctuations in the amount of the infection of these particular plats than to differences in the action of the salt in controlling the disease on the two plats. Considering, therefore, that the treatment very evidently failed in the Flora orchard and showed so small a difference in the Clay City orchard as to be accounted for by the factor of variation in infection, it is concluded that applications of salt to the ground under the trees are useless as preventives of bitter rot.

\section{CONCLUSIONS}

r. Bordeaux mixture properly made and applied will save over 90 percent of the fruit liable to attack by bitter rot.

2. Fruit sprayed in such a manner as to be thoroughly coated with the spray mixture when the first infection of the disease appears will be injured least by bitter rot.

3. Spraying until the fruit is completely coated with the mixture as soon as the first infection of bitter rot is discovered is of considerable value but is much less effective than the treatment mentioned above. 
4. Spraying until the fruit is completely coated with the mixture after bitter rot has become thoroughly established is effective in controlling as much as 50 percent of the disease during some seasons. In other seasons its effect as a remedy is very slight.

5. Bordeaux mixture applied in the liquid form is the most effective spraying material for the control of apple bitter rot.

6. Dust spray is ineffective in preventing bitter rot.

7. Pure copper sulphate solution failed to check the disease and caused injury to the foliage.

8. To coat fruit thoroughly with the mixture it is necessary to make at least three applications of the spray material.

9. Applications of twenty-five pounds of salt to the ground about a tree have no value in checking the disease.

IO. The conditions most favorable for the development of bitter rot are (I) a period of hot weather accompanied by frequent rains and heavy dews at a period when the apple crop is approaching maturity, $i$. e., from the middle of July to the end of August. Numerous sources of infection, $i$. e., cankers on the limbs and mummied fruits left hanging upon the trees.

\section{RECOMMENDATIONS FOR THE 'TREATMENT OF BIT'TER ROT}

I. In addition to the three early sprayings for apple scab and codling moth make applications of Bordeaux mixture at intervals of ten days commencing the third week in June and continuing the operation until the appearance of bitter rot, or, in case bitter rot fails to appear, until the end of July; in all, four applications if the rot appears before the end of July, or five applications if it does not.

NoTE-In most seasons three applications of standard Bordeaux mixture, one applied the last week in June and the two following at intervals of ten days, are sufficient to prevent the disease. Owing, however, to the irregularity of the time of infection in different seasons this practice is not wholly safe, and the extra treatments are recommended as a wise precaution.

2. In case the precautionary sprayings above recommended are not given, the most thorough sprayings to coat the fruit completely with Bordeaux mixture should be given on the first discovery of bitter rot in the orchard. Failure to spray promptly at this time will result, in a season favorable for the development of the disease, in almost complete destruction of the crop.

3. Mummies of apples which remain upon the tree during the winter should be picked off and destroyed in order to eliminate this source of infection the following summer.

4. In the accompanying bulletin on the botany of bitter rot (No. II 8 ) by Dr. T. J. Burrill will be found a full account of the bitter rot canker, one of the forms in which the fungus is carried over winter. The cankers should be cut off and burned, the limb 
being cut a few inches below the cankered spot. Care should be taken not to cause fresh bruises in the bark of other branches while this operation is being performed, and the pruning tools should not be allowed to touch the canker for fear of carrying the infection to the freshly cut surfaces below the diseased bark.

\section{ACKNOWLEDGMENTS}

I wish at this time to convey my grateful acknowledgments to the many persons who have assisted in carrying out the experiments outlined in this bulletin, particularly to the owners of the various orchards who so kindly placed their trees at the disposal of the Department of Horticulture, and to the Department Assistants on whose faithful attention to the details of the various experiments the success ${ }^{\circ}$ of the work largely depended. At various times the following Department men have been connected with this work:

Mr. A. V. Stubenrauch, who had charge of field work during Igor and a part of 1902 .

Mr. R. A. Simpson, who conducted the experiments in the Simpson orchard at Parkersburg in I90I.

Mr. W. S. Hotchkiss, who was in charge of field investigations in 1902.

Mr. H. Hasselbring, who was in charge of botanical investigations in $\mathrm{I} 902$.

Mr. A. W. Bryant, who had charge of field work in the Tamaroa, Flora, and Tonti orchards in 1902.

Mr. G. M. Bradford, for a part of the season of 1903 in charge of the New Burnside and Carbondale orchards.

Professor Charles S. Crandall, who was responsible for the experiments in the Flora, Tamaroa, and Olney orchards in 1903 and for a large amount of the record work in 1904 and 1905.

Mr. C. B. Dull, who was in charge of the field work at Flora, Tamaroa, and Olney in 1903, and at Flora and Olney in 1904.

Mr. R. B. Howe, who conducted the field work at Tamaroa and Kell in I904, and at Flora in 1905.

Mr. J. R. Shinn, who was in charge of the field work at Clay City in I905.

Mr. B. S. Pickett, who has collected and arranged the data gathered during the progress of the experiments and has prepared the various tables presented in this bulletin. 


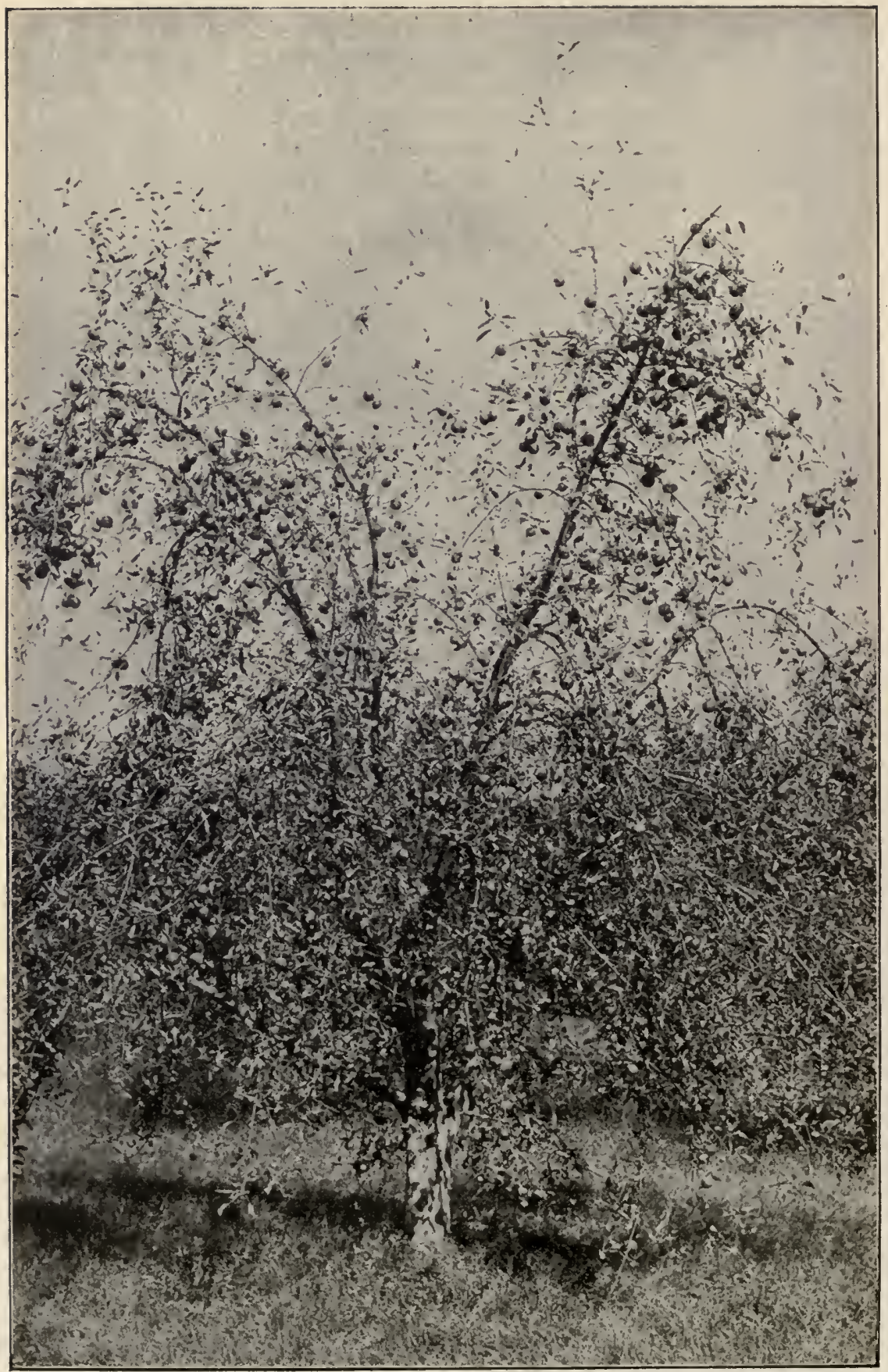

Tree No. 8 of Plat No. 12. Clay City Orchard. Sprayed with StandARD Bordeadx MiXTURe. TOTAL APPlers, 2257; APPLes AFFeCted BY BITTER Rot, 443; Hercentage AFFected by BITTER Rot, 19.63. Photograph SePtemBER 26, 1905. 
190\%.] Bitter Rot of Apples, Horticultural Investigations.

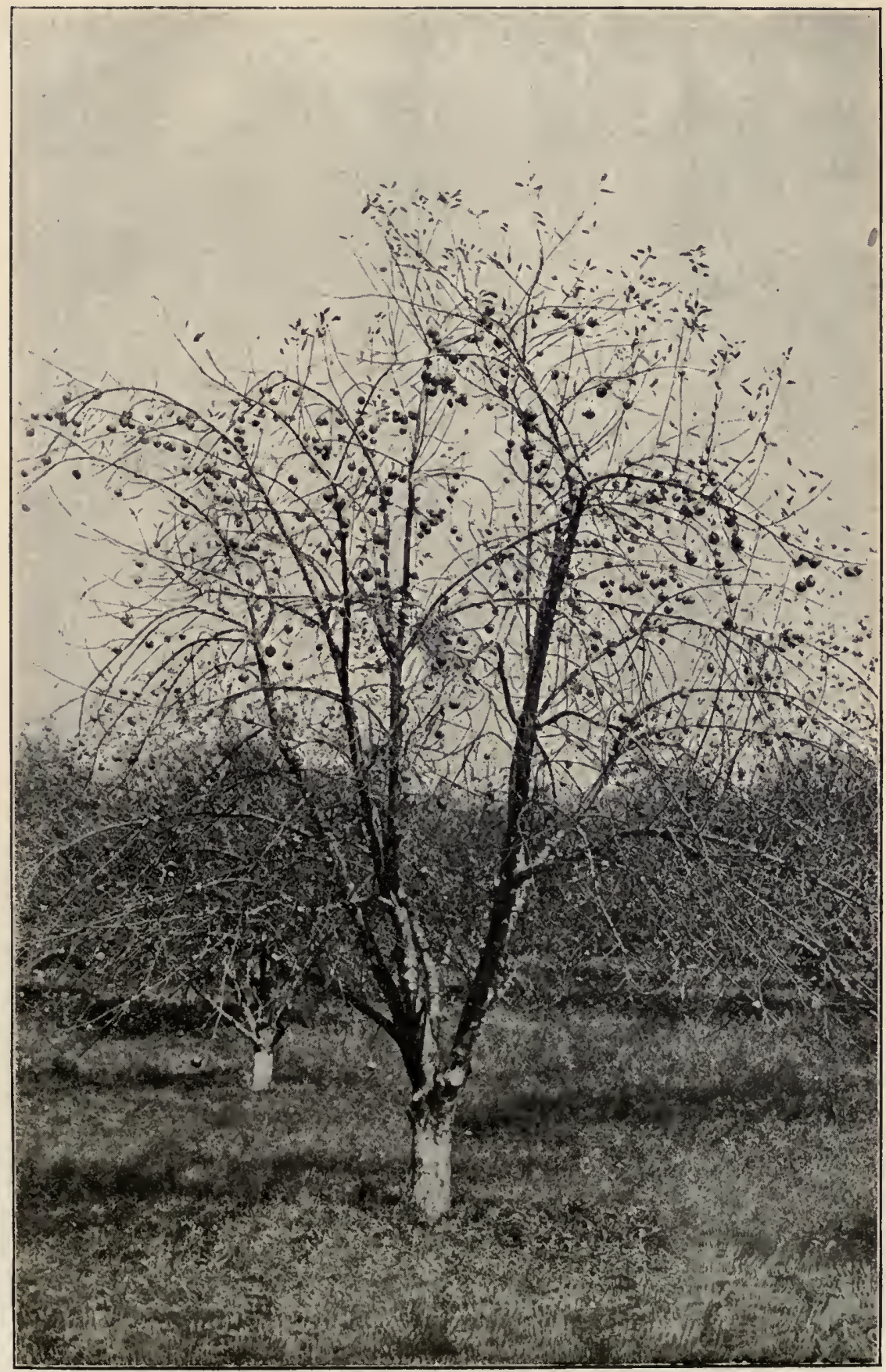

Tree No. 10 of Plat No. 11. Cray City Orchard. Check, Not Sprayed. TOTAL NUMBER OF APPles, 2110: NUMBER OF APPLES AFFECTED BY BITTER Rot, 933; Percentage AFFeCted by Bitter Rot, 44.22. Photograph SeptemBER 26, 1905. 










dich 1 55 -

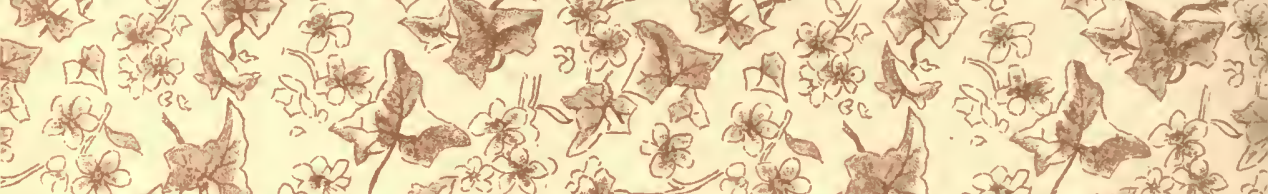
* (3)

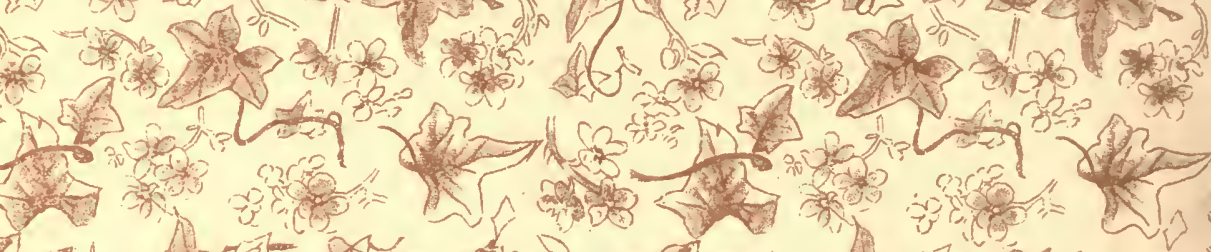

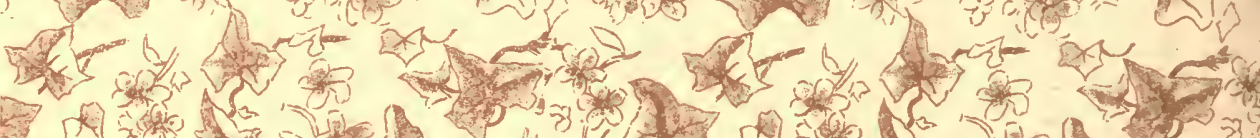

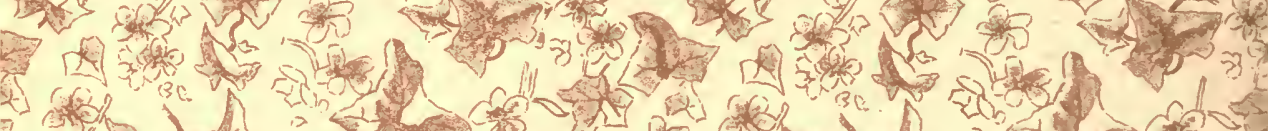
- - I - J (1) 1. 5 (1)

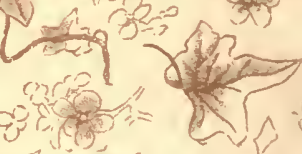
- 1 (a)

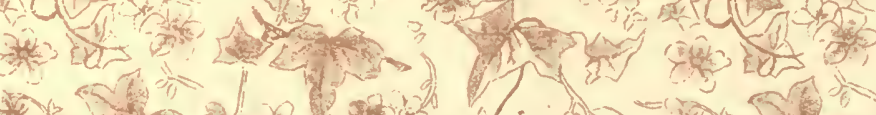

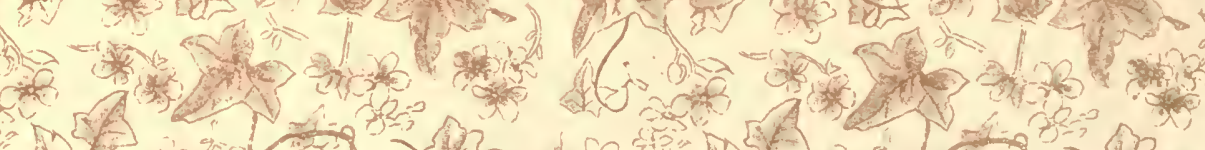
N.

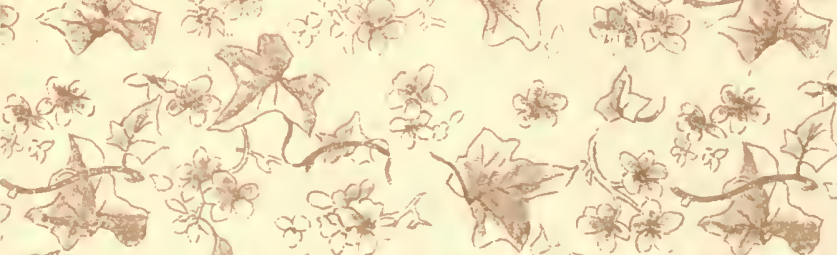



-

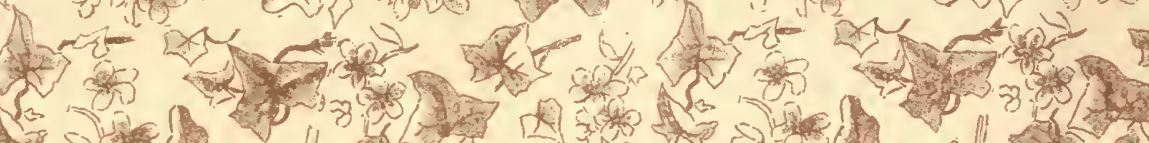

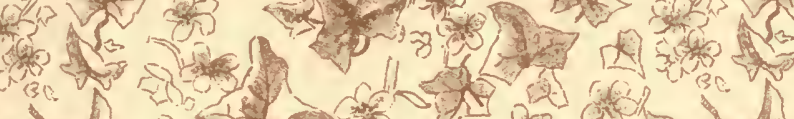
(1) a

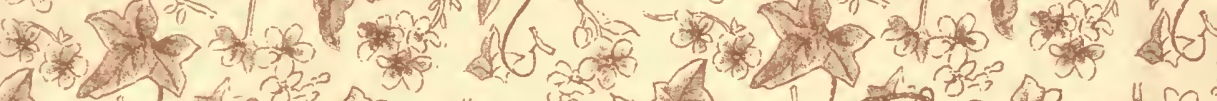

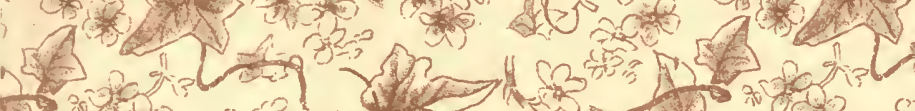
Si a

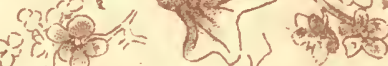

स 5 कर

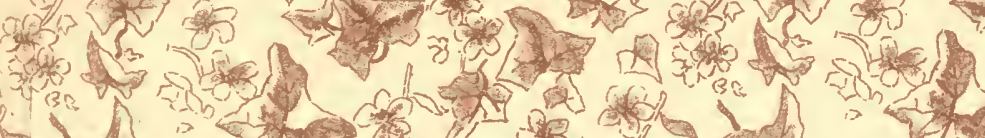

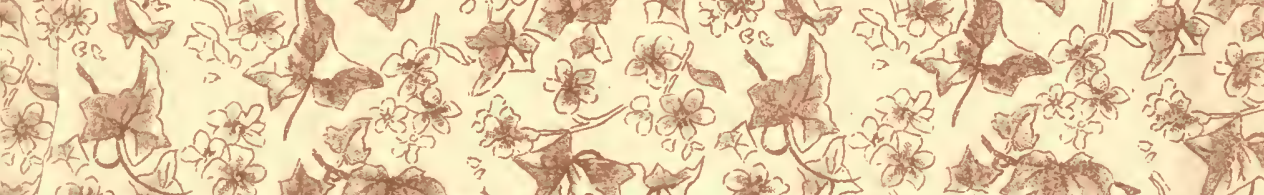

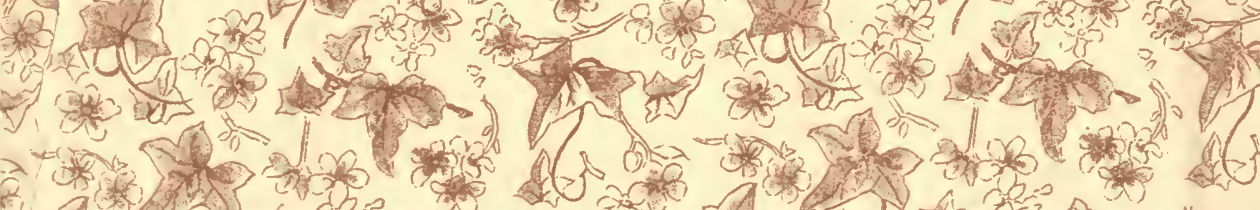

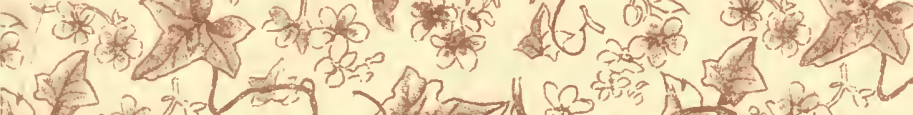

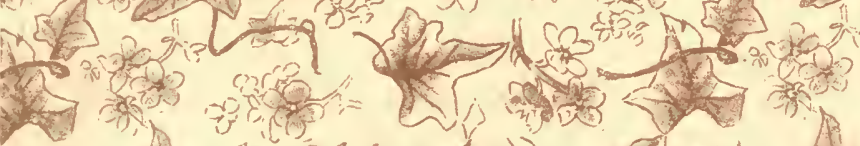<smiles>[CH]</smiles>

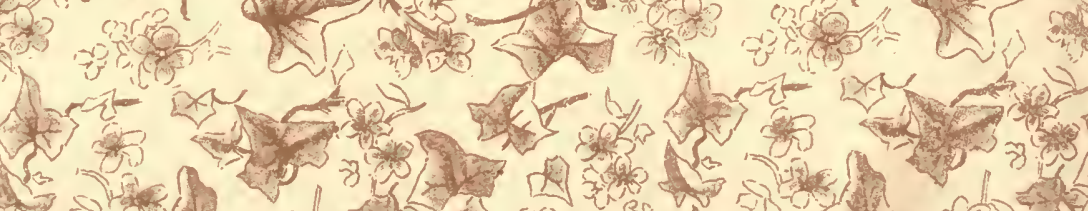
(2) 1. Sold 
UNIVERSTY OF ILINOIS-URBANA 